\title{
NEW AND NOTEWORTHY LICHEN-FORMING AND LICHENICOLOUS FUNGI 5*
}

\author{
S. Y. Kondratyuk ${ }^{1 \neq, 2}$, L. LöKö ${ }^{3}$, J. P. Halda ${ }^{4}$, D. K. Upreti ${ }^{5}$, G. K. Mishra ${ }^{5}$

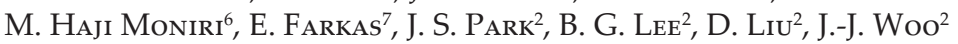 \\ R. G. U. JAYALAL ${ }^{8}$ S.-O. OH ${ }^{9}$ and J.-S. Hur ${ }^{2}$ \\ ${ }^{1}$ M. H. Kholodny Institute of Botany \\ Tereshchenkivska str. 2, 01004 Kiev, Ukraine; ${ }^{*}$-mail: ksya_net@ukr.net \\ ${ }^{2}$ Korean Lichen Research Institute, Sunchon National University \\ Sunchon 540-742, Republic of Korea; E-mail: jshur1@sunchon.ac.kr \\ ${ }^{3}$ Department of Botany, Hungarian Natural History Museum \\ H-1431 Budapest, Pf. 137, Hungary; E-mail: lokos@bot.nhmus.hu \\ ${ }^{4}$ Muzeum a galerie Orlických hor, Jiráskova 2, 51601 Rychnov nad Kněžnou, Czech Republic \\ ${ }^{5}$ CSIR-National Botanical Research Institute \\ Rana Pratap Marg, Lucknow-226001 Uttar Pradesh, India; E-mail: upretidknbri@gmail.com \\ ${ }^{6}$ Department of Biology, Faculty of Sciences, Mashhad Branch, Islamic Azad University \\ Mashhad, Iran; E-mail: hmoniri@yahoo.com \\ ${ }^{7}$ Institute of Ecology and Botany, Centre for Ecological Research \\ Hungarian Academy of Sciences, H-2163 Vácrátót, Alkotmány u. 2-4, Hungary \\ ${ }^{8}$ Department of Natural Resources, Faculty of Applied Sciences \\ Sabaragamuwa University of Sri Lanka, Belihulova 70140 Sri Lanka \\ ${ }^{9}$ Korean National Arboretum, 415 Gwangneungsoomokwon-ro, Soheul-eup \\ Pocheon-Si, Gyeonggi-Do 11186, Republic of Korea
}

(Received 10 June, 2016; Accepted 5 August, 2016)

Data on 54 new for China, India, Korea and Russia species of lichen-forming and lichenicolous fungi, including 22 new for science taxa of lichen-forming and lichenicolous fungi, i.e.: Acarospora ulleungdoensis, Amandinea trassii, Aspicilia geumodoensis, Biatora ivanpisutii, Caloplaca patwolseleyae, Catillaria ulleungdoensis, Coenogonium agonimieoides, Gyalidea austrocoreana, G. ropalosporoides, Opegrapha briancoppinsii, O. ulleungdoensis, Phyllopsora loekoesii, Psoroglaena coreana, Psorotichia gyelnikii, Rinodina oxneriana, Scoliciosporum jasonhurii, Staurothele oxneri, Stigmidium coarctatae, Thelocarpon ulleungdoense, Thelopsis loekoesii, Toninia poeltiana, Unguiculariopsis helmutii, and and 7 new species to China (Caloplaca ussuriensis, Megaspora rimisorediata, Rinodina xanthophaea, Rusavskia dasanensis, Xanthoria splendens, Zeroviella coreana, Z. esfahanensis), and 1 new species to India (Zeroviella esfahanensis), and 24 new species to Korea (Agonimia blumii, Arthonia rinodinicola, Buelliella minimula, Dactylospora australis, Endococcus propinguus, Halecania santessonii, Laeviomyces aff. fallaciosus, Lecanora albescens, L. layana, Lecidella scabra, Micarea farinosa, Minutoexcipula aff. mariana, Opegrapha anomaea, O. aff. xerica, Phoma aff. lecanorina, Polycoccum rubellianae, Porina nucula, Pyrenidium actinellum, Rhexophiale rhexoblephara, Rimularia badioatra, Rinodina confragosa, $R$. milvina, $R$. occulta, Tremella phaeophysciae), as well as 1 new species to Russia (Verseghya klarae) are provided. Furthermore new for science species of lichenicolous fungus Polycoccum clauderouxii from

* Previous contributions were published in 2013, 2015 and 2016 (Kondratyuk et al. 2013a, $2015 a, b, 2016 a)$. 
China is described. Four new combinations, i.e.: Biatora pseudosambuci (Basionym: Lecanora pseudosambuci S. Y. Kondr., L. Lőkös et J.-S. Hur), Buellia pseudosubnexa (Basionym: Hafellia pseudosubnexa S. Y. Kondr., L. Lőkös et J.-S. Hur), Buellia extremoorientalis (Basionym: Hafellia extremorientalis S. Y. Kondr., L. Lőkös et J.-S. Hur), and Sagedia nunatakkorum (Basionym: Lecanora nunatakkorum Poelt) are proposed. Data on conidiomata and conidia for lichenicolous fungus Opegrapha anomea Nyl are for the first time provided.

Key words: Acarospora, Aspicilia, Biatora, Buellia, Catillaria, Coenogonium, Gyalidea, Korea, Opegrapha, new for science, Phyllopsora, Polycoccum, Psoroglaena, Psorotichia, rare, Rinodina, Scoliciosporum, Staurothele, Stigmidium, Thelocarpon, Thelopsis, Toninia, Unguiculariopsis

\section{INTRODUCTION}

Additional 46 new species of lichen-forming and lichenicolous fungi and some more occurrence records to the Korean lichen flora, as well as further contributions to the lichen flora of other Asian areas (India, China, etc.) are provided as a continuation of our former papers (Kondratyuk et al. 2013a, $2015 a, b, 2016 a)$.

\section{MATERIALS AND METHODS}

This contribution is based on a total of 2,500 specimens, which were sampled during the current collections in 2015 and 2016, and these are deposited in the Korean Lichen Research Institute, Sunchon National University, South Korea (hereafter: KoLRI), as well as some duplicates in the Hungarian Natural History Museum (hereafter: BP) and the Lichen Herbarium of M. $\mathrm{H}$. Kholodny Institute of the Botany of the National Academy of Sciences of Ukraine (hereafter: KW-L).

The specimens were examined using standard microscopical techniques and hand-sectioned under a dissecting microscope (Nikon SMZ 645; Nikon, Tokyo, Japan). Anatomical descriptions were based on observations of these preparations under a microscope (Nikon Eclipse E200; Nikon, Tokyo, Japan, and Zeiss Scope. A1; Carl Zeiss, Oberkochen, Germany) with digital camera AxioCam ERc 5s. Section of apothecia were tested with water and with $\mathrm{K}$ and IKI (10\% aqueous potassium iodide) for identification.

For identification chemical substances of critical taxa standard TLC and HPTLC methods with solvent C were carried out (Arup et al. 1993, Orange et al. 2001). 


\section{RESULTS AND DISCUSSION \\ New for science taxa}

\section{Acarospora ulleungdoensis S. Y. Kondr., L. Lőkös et J.-S. Hur, spec. nova} (Fig. 1)

Mycobank no.: MB 817966

Similar to Acarospora suzai, but differs in having smaller and indistinct thallus, in having smaller and thinner thalline areoles, in having smaller apothecia with violet-brown disc, in having badly developed true exciple, in having very thin subhymenium, in having larger asci containing 100-200 ascospores, as well as in having somewhat wider ascospores.

Type: Republic of Korea. Gyeongsangbuk-do, Ulleung-do Island, Ulleung-gun, Seomyeon, Taeha-ri, valley of Tae-hacheon, Seodal-gil, on siliceous rocks, growing together with Trapelia coarctata damaged by lichenicolous fungus, Trapelia placodioides. Lat.: $37^{\circ} 30^{\prime}$ 12.77" N; Long.: 130 49' 49.03" E; Alt.: 265 m a.s.l. Coll.: Woo, J.-J. (160708), 10.07.2016 (holotype: KoLRI 040946); the same locality, Coll.: Kondratyuk, S. Y. and Lőkös, L., 10.07.2016; (161849), (isotype: KoLRI 040081); the same locality, growing together with Acarospora
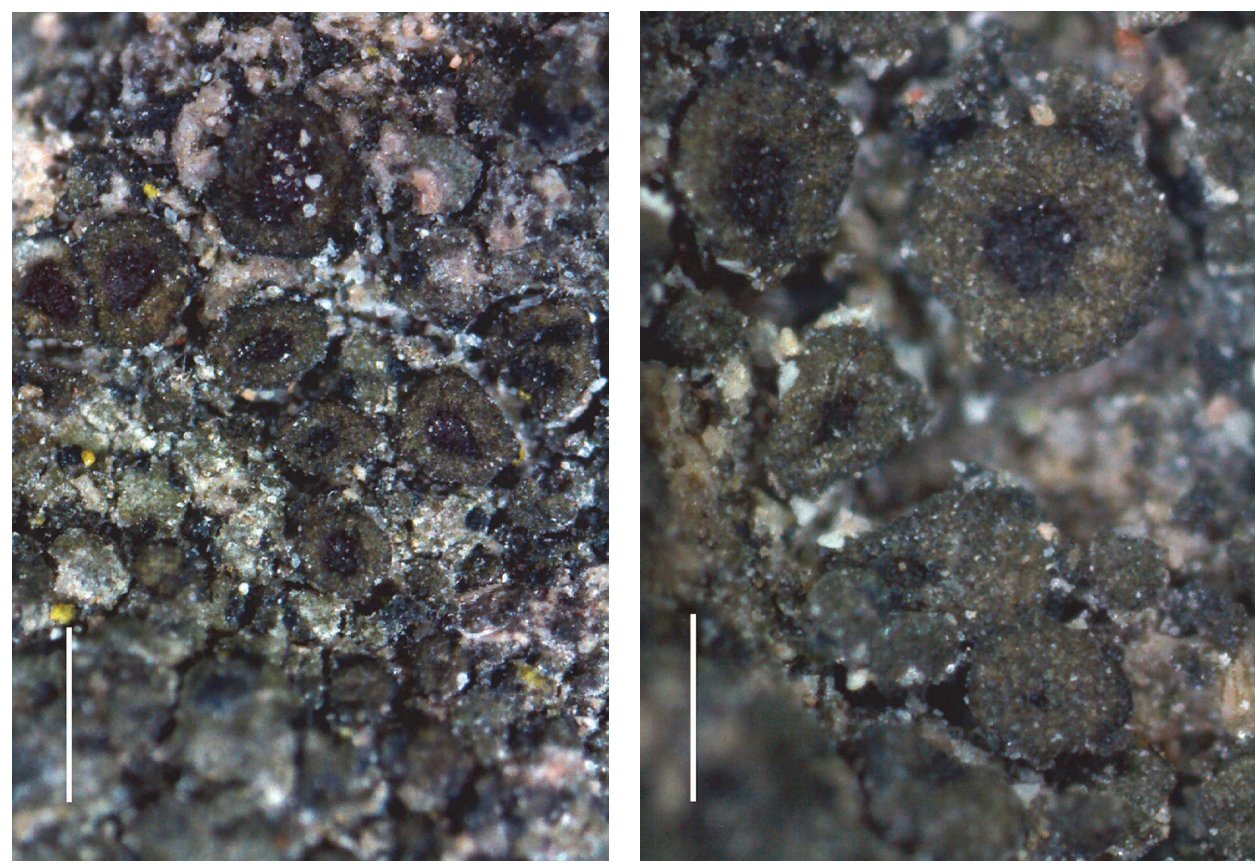

Fig. 1. Acarospora ulleungdoensis, general habit (holotype). Scale $0.5 \mathrm{~mm}$ (right) $1 \mathrm{~mm}$ (left) and (photo: S. Kondratyuk) 
aff. moenium, Caloplaca aff. oxfordensis, (161955), (isotype: KoLRI 040192 sub Acarospora aff. moenium); the same locality, growing together with Acarospora aff. moenium, Caloplaca aff. oxfordensis 161959 (isotype: KoLRI 040196 sub Acarospora aff. moenium); the same locality, growing together with Caloplaca aff. oxfordensis, Buellia and Caloplaca chejuensis, 161962 (isotype: KoLRI 040199 sub Caloplaca aff. oxfordensis); the same locality, growing together with Caloplaca aff. oxfordensis, Pyrenopsis chejudoensis, Buellia and Caloplaca chejuensis, 161975 (isotype: KoLRI 040212 sub Caloplaca aff. oxfordensis).

Thallus very indistinct, consisting of solitary, very distant and dispersed among another lichens single areoles; areoles $0.2-0.3(-0.6) \mathrm{mm}$ in diam./ across, rather scattered and distant each other, dark green or dark greenish brown, very thin, in section to $55 \mu \mathrm{m}$ thick.

Apothecia $0.4-0.5(-0.6) \mathrm{mm}$ in diam., and to $0.15 \mathrm{~mm}$ thick, solitary, 1 per areole, immersed into thalline areole or with thick thalline margin to $0.1-0.13$ $\mathrm{mm}$ wide, dark green or greenish brown, disc dark violetish brown; in section true exciple to 30-40 $\mu \mathrm{m}$ thick in the uppermost lateral portion and very thin, to $10 \mu \mathrm{m}$ thick in lower lateral and basal portions, paraplectenchymatous, sometimes indistinct; hymenium to 100-110 $\mu \mathrm{m}$ high, with bright yellow or yellowish brown epihymenium to 20-30 $\mu \mathrm{m}$ thick; paraphyses distinctly swollen towards the tips, to 4-5 $\mu \mathrm{m}$ wide at the tips; asci 70-75 $\times 18-25(-30)$ $\mu \mathrm{m}$ with 100-200 ascospores; ascospores elongated to widely ellipsoid or almost spherical, 3-5(-6) × 2-2.5(-3) $\mu \mathrm{m}$.

Ecology: On siliceous rocks in coastal zone.

Distribution: So far known only from scattered localities in South Korea, Eastern Asia.

Etymology: It is named after Ulleung-do Island (South Korea, Eastern Asia), where type material of this taxon was collected.

Taxonomic notes: Acarospora ulleungdoensis is similar to A. suzai H. Magn., growing on siliceous rocks in Europe (Czech Republic, Hungary and Italy), in having solitary apothecia, which immersed 1 per thalline areole, but differs in having smaller and indistinct thallus (vs. to $5 \mathrm{~cm}$ in diam.), in having smaller thalline areoles (to $0.2-0.3(-0.6) \mathrm{mm}$ vs. $0.4-1.5 \mathrm{~mm}$ across), in having much thinner thallus (to $55 \mu \mathrm{m}$ thick vs. to $400 \mu \mathrm{m}$ thick, including cortical layer to 15-40 $\mu \mathrm{m}$ thick, algal layer to 60-175 $\mu \mathrm{m}$ thick, medullary layer to 400 $\mu \mathrm{m}$ thick and lower cortical layer well developed to 8-12 $\mu \mathrm{m}$ thick), in having smaller apothecia (0.4-0.5(-0.6) mm vs. $0.3-0.8 \mathrm{~mm}$ in diam.), in having thick thalline margin (vs. without or with thin thalline margin), in having violetbrown (vs. reddish brown) disc, in having weakly developed true exciple (to $10 \mu \mathrm{m}$ vs. to 30-40 $\mu \mathrm{m}$ thick below subhymenium, paraplectenchymatous with thick walled cells), in having slightly wider tips of paraphyses (4-5 $\mu \mathrm{m}$ vs. to $4.3 \mu \mathrm{m})$, in having larger asci $(70-75 \times 18-25(-30) \mu \mathrm{m}$ vs. $50-60 \times 14-17$ $\mu \mathrm{m})$, which contain much higher number of ascospores (100-200 vs. ca 100), 
while ascospores are almost the same size $(3-5(-6) \times 2-2.5(-3) \mu \mathrm{m}$ vs. $3-5.5 \times$ 2-2.5 $\mu \mathrm{m}$ ), as well as in the lack of lower cortical layer and black underside of thalline areoles (Golubkova 1978).

Acarospora ulleungdoensis is similar to A. durietzii $\mathrm{H}$. Magn., known from siliceous rocks of Europe and Greenland, but differs in having areolate (vs. squamulose) and green (vs. dark pure brown) thallus, in having smaller thalline areoles $(0.2-0.3 \mathrm{~mm}$ in diam./across, vs. squamules $0.2-1.2 \mathrm{~mm}$ in diam.), in having thinner thallus (total thickness to $55 \mu \mathrm{m}$ thick, vs. total thickness 0.4-0.5 mm thick, including upper cortex 25-45 $\mu \mathrm{m}$ thick, algal layer 50-100 $\mu \mathrm{m}$ thick, medullary layer to $300 \mu \mathrm{m}$ thick), as well as in having larger and narrower ascospores $(3-5(-6) \times 2-2.5(-3) \mu \mathrm{m}$ vs. $3-4.3 \times 1.8-2.5 \mu \mathrm{m})$, while apothecia and asci are almost the same.

Other specimen examined: Republic of Korea. Jeollanam-do, Yeosu-si, Nam-myeon, Geumo-do, Simjang-ri, on rock, growing together with Caloplaca aff. holocarpa and Endocarpon sp. Lat.: $34^{\circ} 30^{\prime} 52.5^{\prime \prime}$ N; Long.: $127^{\circ} 43^{\prime} 36.6^{\prime \prime}$ E; Alt.: ca 71 m a.s.l. Coll.: Kondratyuk, S. Y. (160405), 10.06.2016 (KoLRI 038550 sub Caloplaca aff. holocarpa).

Amandinea trassii S. Y. Kondr., L. Lőkös et J.-S. Hur, spec. nova (Fig. 2)

Mycobank no.: MB 817967

Similar to Buellia griseovirens, but differs in having well-developed thallus, in having larger thalline areolae, in having smaller soredia, in having larger photobiont cells, in having smaller apothecia, in having 1-septate and smaller ascospores, as well as in the lack of $\mathrm{C}+$ and $\mathrm{K}+$ reactions.

Type: Republic of Korea. Gyeongsangbuk-do, Uljin-gun, Jukbyeon-myeon, Jukbyeon-ri, Jukbyeon 10-gil, roadside trees along the street, on bark of Pinus. Lat.: $37^{\circ} 03^{\prime}$ 27.19" N; Long.: $129^{\circ} 25^{\prime}$ 03.82" E; Alt.: $10 \mathrm{~m}$ a.s.l. Coll.: Kondratyuk, S. Y. (SK 102) and Lőkös, L. (151358), 11.07.2015 (holotype: KoLRI 034591).

Thallus to several $\mathrm{cm}$ across in irregular spots, seen as greenish-greyish spots, indistinct, at large magnification ( $\times 100$ and more) cracked, somewhat not continuous, areoles (0.2-)0.4-0.8(-1) mm across with more or less even (not convex) upper surface, pale greyish or whitish-greyish to darker greenish grey, usually abundantly sorediate. Soralia usually very indistinct, from more or less rounded (0.15-)0.2-0.3 mm in diam. at first to fissure-like or confluent later; soredious mass concave at first but later to more or less convex in places, whitish to dark brownish, grey or dark bluish-brownish grey; soredia very small, $c a(12.5-) 17-20(-30) \mu \mathrm{m}$ in diam., mainly regularly rounded, but sometimes somewhat of irregular shape, usually whitish but becoming dark brown- 
ish, grey or dark bluish-brownish grey along the edges of soralia, with hyphal layer to 3-4 $\mu \mathrm{m}$ thick, which becoming brownish in outer portion in places.

Thallus in section to (50-)60-70 $\mu \mathrm{m}$ thick, cortical layer 10-15(-20) $\mu \mathrm{m}$ thick, paraplectenchymatous at least in lower portion while upper portion often with epinecral layer; algal zone to $35-45 \mu \mathrm{m}$ thick, algal cells 11-17(-22) $\mu \mathrm{m}$ diam., medullary layer as separate layer usually not developed.

Apothecia $0.15-0.25 \mathrm{~mm}$ in diam., in section to $0.1 \mathrm{~mm}$ thick, often numerous in places, usually 1 per areole, slightly immersed into the thallus at first, later becoming slightly uplifted, sessile, disk from plane to semiconvex; in section lecideine, true exciple to $15-25 \mu \mathrm{m}$ wide, dark brown to blackish brown in lateral portion; hymenium 35-45 $\mu \mathrm{m}$ high, epihymenium to 5-7 $\mu \mathrm{m}$ thick, somewhat blackish, paraphysis tips distinctly swollen to $3-5 \mu \mathrm{m}$ wide, dark brown or blackish brown; subhymenium 40-50(-70) $\mu \mathrm{m}$ thick, brownish; asci 8-spored, 32-35 × 11-13 $\mu \mathrm{m}$; ascospores 1-septate, ellipsoid to slightly curved, greenish-blackish at first then dark brown, (8-)10-13(-15) $\times 5-6(-7) \mu \mathrm{m}$.

Chemistry: Thallus and soralia $\mathrm{K}-, \mathrm{C}-, \mathrm{Pd}-$.

Ecology: On bark of pine trees (Pinus densiflora and P. thunbergii).

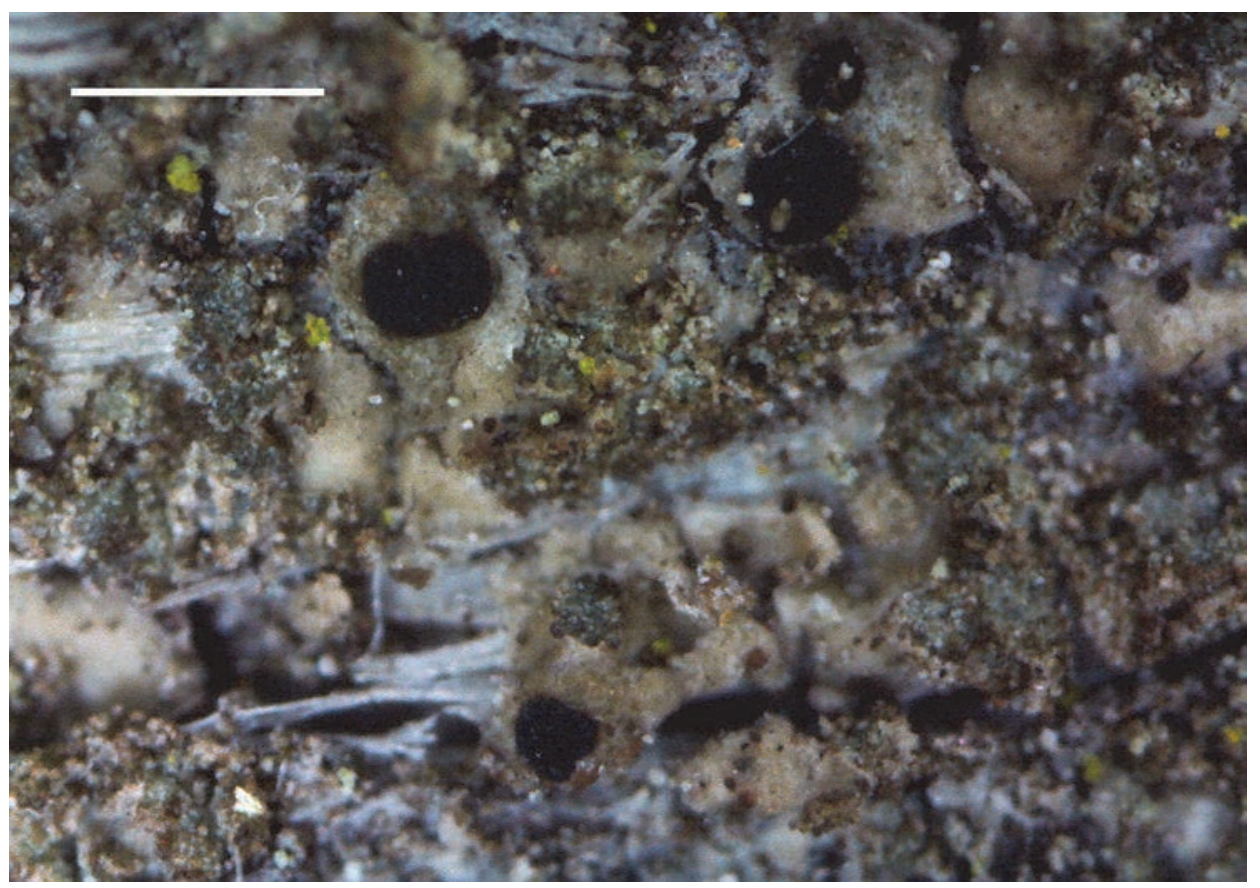

Fig. 2. Amandinea trassii (holotype), general habit. Scale $0.5 \mathrm{~mm}$ (photo: S. Kondratyuk) 
Distribution: It is known so far from scattered localities in South Korea, Eastern Asia.

Etymology: It is named after the well-known Estonian lichenologist Hans Trass (1928-) in recognition of his contribution to recent knowledge on the Physciaceae and Buelliaceae of the Asian continent.

Taxonomic notes: After having greyish white or dark grey with a bluish tinge, mostly circular in outline, rarely fissure-shaped often surrounded laterally by a lacerate cortical sheet, up to $0.3 \mathrm{~mm}$ diam. soralia Amandinea trassii is similar to Buellia griseovirens (Sm.) Almb., but differs in having well-developed thallus (vs. endosubstratal or episubstratal sensu Tønsberg 1992), in having larger thalline areoles $(0.4-0.8(-1) \mathrm{mm}$ vs. to $0.4 \mathrm{~mm}$ in diam.), in having smaller soredia ((12.5-)17-20(-30) $\mu \mathrm{m}$ vs. $20-40 \mu \mathrm{m}$ in diam.), in having larger photobiont cells $(11-17(-22) \mu \mathrm{m}$ vs. $8-12 \mu \mathrm{m}$ in diam.), in having very small apothecia (0.15-0.25 $\mathrm{mm}$ vs. to $2 \mathrm{~mm}$ in diam. after Tønsberg (1992), or 0.4-1 $\mathrm{mm}$ diam. after Orange et al. (1992)), in having 1-septate and smaller ((8-)10$13(-15) \times 5-6(-7) \mu \mathrm{m}$ vs. submuriform, (13-)15-28 × 7-13 $\mu \mathrm{m})$, as well as in the lack of $\mathrm{C}+$ yellowish reaction, $\mathrm{Pd}+$ yellow or yellow-orange, and $\mathrm{K}+$ fuscous brown reactions, and in the lack of atranorin, norstictic and connorstictic acids and 'griseovirens unknown' substance (data on Buellia griseovirens are provided after Tønsberg (1992)). Furthermore after phylogenetical analysis of the members of the family Buelliaceae based on nrITS sequences material of Amandinea trassii is member of the Amandinea branch, while Buellia griseovirens is positioned in the Buellia clade (Kondratyuk et al., in prep.).

Amandinea trassii is similar to Buellia arborea Coppins et Tønsberg usually growing on decorticated trunks of Pinus sylvestris in Atlantic and Central Europe, which is similar to Buellia griseovirens when sterile, but having $\mathrm{C}$ - thallus and $\mathrm{Pd}-$ soralia, but differs in having 1-septate and smaller (vs. 1-3-septate, $(17.5-) 19-25(-28) \times(7.5-) 8.5-10(-12) \mu \mathrm{m})$, as well as in the lack of $\mathrm{K}+$ fuscous brown reactions, and in the lack of norstictic and other substances of the stictic acid complex (data on Buellia arborea are provided after Tønsberg 1992).

Other specimens examined: Republic of Korea. Gangwon-do, Sacheon-myeon, Gadunji-gil, small pine plantation along the seashore road (Haean-ro) at Sacheon Beach, on bark of Pinus densiflora and P. thunbergii. Lat.: $37^{\circ} 49^{\prime} 43.21^{\prime \prime}$ N; Long.: $128^{\circ} 52^{\prime} 41.50^{\prime \prime}$ E; Alt.: $5 \mathrm{~m}$ a.s.l. Coll.: Kondratyuk, S. Y. (150827), 09.07.2015 (KoLRI 034060). - Jeju-do, Jeju-si, Chuja-do, Chuja-myeon, Sinyang-1-ri, seashore of Mojini-mongdol, on bark of Pinus. Lat.: 33 56' 44.9" N; Long.: $126^{\circ} 20^{\prime}$ 03.01" E; Alt.: 57 m a.s.l. Coll.: Kondratyuk, S. Y. (SK-07). (140901-6), 21.06.2014 (KoLRI 023421); the same locality, (140922-4), (KoLRI 023453); the same locality, growing together with Lecanora, (140934-4), (KoLRI 023473). 
Aspicilia geumodoensis S. Y. Kondr., L. Lőkös et J.-S. Hur, spec. nova (Fig. 3)

Mycobank no.: MB 817968

Similar to Aspicilia tofacea, but differs in having larger thalline areoles, in having larger apothecia, in having lower hymenium, and in having larger ascospores, as well as in containing gyrophoric acid and in the lack of $K+$ yellow then reddish reaction of the medulla.

Type: Republic of Korea. Jeollanam-do, Yeosu-si, Nam-myeon, Geumo-do, Simjangri, on rock, growing together with Lepraria and Endocarpon spp. Lat.: $34^{\circ} 31^{\prime} 19.7^{\prime \prime}$ N; Long.: $127^{\circ} 43^{\prime}$ 52.1" E; Alt.: ca 51 m a.s.1. Coll.: Kondratyuk, S. Y. (160406), 10.06.2016 (holotype: KoLRI 038551); the same locality, growing together with Pyxine, Lepraria and Caloplaca sp., (160418), (isotype: KoLRI 038563); the same locality, growing together with Lecania, Lepraria and Endocarpon sp., (160416), (isotype: KoLRI 038561); the same locality, growing together with Caloplaca sp., (160414), (isotype: KoLRI 038559).

Thallus crustose, distinctly areolate, whitish grey; areoles $0.7-1.3(-1.7)$ $\mathrm{mm}$ across, irregular. Thallus to 130-200(-270) $\mu \mathrm{m}$ thick in section, somewhat thicker around apothecium; cortical layer to $20-30 \mu \mathrm{m}$ thick, with somewhat
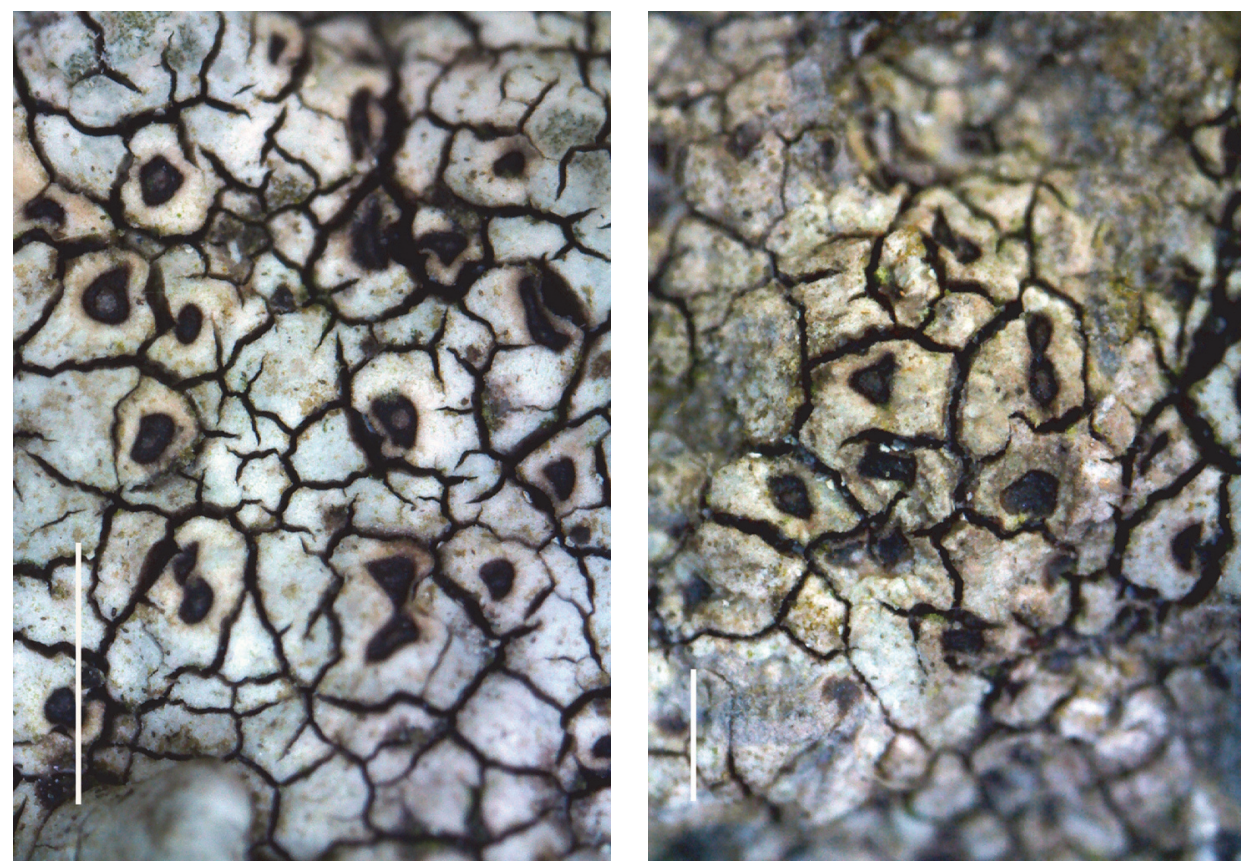

Fig. 3. Aspicilia geumodoensis, general habit (holotype). Scale $1 \mathrm{~mm}$ (left) and $0.5 \mathrm{~mm}$ (right) (photo: S. Kondratyuk) 
brownish upper portion to 10-15 $\mu$ m thick, paraplectenchymatous, cell lumina $5-8 \mu \mathrm{m}$ in diam./across; algal zone to $50 \mu \mathrm{m}$ thick, algal cells to $13-20$ $\mu \mathrm{m}$ in diam.

Apothecia $0.4-0.7(-0.8) \mathrm{mm}$ in diam./across, in section to $0.25-0.4(-0.8)$ $\mathrm{mm}$ in diam., and to $150-180(-300) \mu \mathrm{m}$ thick, (nucleus to $130-170 \mu \mathrm{m}$ in diam. and to $150-170 \mu \mathrm{m}$ thick), immersed into thalline areoles and with slightly distinct, slightly rising above level of apothecium thalline margin, concolorous with thallus, whitish grey; disc blackish, sometimes thalline margin well distinct, to $0.1 \mathrm{~mm}$ thick; true exciple to (10-)15-30 $\mu \mathrm{m}$ thick in lateral portion and to $40 \mu \mathrm{m}$ thick in basal portion, mesodermatous paraplectenchymatous, with distinct matrix and cell lumina 2-5 $\mu \mathrm{m}$ across, hyaline or yellowish to somewhat greyish owing to numerous air inclusions, sometimes in basal or lower lateral portions becoming dark brown to blackish brown in places; hymenium to $110-120(-140) \mu \mathrm{m}$ high, with oil droplets to $5 \mu \mathrm{m}$ in diam., sometimes divided into several portions by vertical brownish portions; epihymenium to (15-)20-30(-35) $\mu \mathrm{m}$ thick, yellowish brown to brown orange or dark brown or greenish brown; paraphyses to $3(-4) \mu \mathrm{m}$ wide, not swollen and not moniliform at the tips (or to 6-8 $\mu \mathrm{m}$ wide and more or less moniliform), in $\mathrm{K}$ becoming brownish; subhymenium to $40 \mu \mathrm{m}$ thick; ascospores simple, hyaline, ellipsoid to widely ellipsoid, (17-)20-25(-30) × (8-)9-13 $\mu \mathrm{m}$, cell wall to $1 \mu \mathrm{m}$ thick.

Chemistry: Thallus K+ yellow, Pd-, C+ red, gyrophoric acid present.

Ecology: On siliceous rocks in coastal zone.

Distribution: So far known only from the type locality in South Korea, Eastern Asia.

Etymology: It is named after Geumo-do Island, where type material of this taxon was collected.

Taxonomic notes: Among Eastern Asian species of Aspicilia described by Hue (1910) in the beginning of the 20th century four species of this genus, i.e. A. tofacea Hue and A. umbrinella Hue, as well as A. asteria Hue and A. nitellina Hue are the most similar to $A$. geumodoensis.

Aspicilia geumodoensis is similar to the Eastern Asian species A. tofacea Hue, but differs in having larger thalline areoles $(0.7-1.3 \mathrm{~mm}$ vs. $0.3-0.6 \mathrm{~mm}$ across), in having larger apothecia $(0.4-0.7 \mathrm{~mm}$ vs. $0.2-0.3 \mathrm{~mm}$ in diam.), in having lower hymenium (110-120 $\mu \mathrm{m}$ vs. 120-130 $\mu \mathrm{m}$ high), and in having larger ascospores $((17-) 20-25(-30) \times(8-) 9-13 \mu \mathrm{m}$ vs. $13-24 \times 10-12 \mu \mathrm{m})$, as well as in containing gyrophoric acid (thallus $\mathrm{C}+\mathrm{red}$ ) and in the lack of $\mathrm{K}+$ yellow then reddish reaction of the medulla.

Aspicilia geumodoensis is similar to another Eastern Asian species A. umbrinella Hue, which is also characterised by whitish in parts or umbrinus, $\mathrm{K}-$ or $\mathrm{K}+$ reddish (?) thallus, but differs in having larger thalline areoles (0.7-1.3 $\mathrm{mm}$ vs. $0.3-0.6(-1) \mathrm{mm}$ across), in having larger apothecia $(0.4-0.7 \mathrm{~mm}$ vs. 
0.2-0.5 $\mathrm{mm}$ in diam.), in having mainly larger ascospores ((17-)20-25(-30) $\times$ (8-)9-13 $\mu \mathrm{m}$ vs. 16-24 × 9-14 $\mu \mathrm{m})$, and in containing gyrophoric acid.

Aspicilia geumodoensis is similar to another Eastern Asian species A. asteria Hue, but differs in having much thinner and white, $\mathrm{K}+$ yellow (to $0.3 \mathrm{~mm}$ thick vs. more than $0.5 \mathrm{~mm}$ thick, grey, $\mathrm{K}-$ ) thallus, in the lack of radially orientated thalline areoles in peripheral zone, in having lower hymenium (110-120 $\mu \mathrm{m}$ vs $130-180 \mu \mathrm{m}$ high), in having mainly larger ascospores ((17-)20-25(-30) $\times$ (8-)9-13 $\mu \mathrm{m}$ vs. 16-20 × 10-14 $\mu \mathrm{m})$, and in containing gyrophoric acid.

Aspicilia geumodoensis is similar to another Eastern Asian species A. nitellina Hue, but differs in having white, $\mathrm{K}+$ yellow (brown, $\mathrm{K}-$ ) thallus, in having larger apothecia (0.4-0.7 $\mathrm{mm}$ vs. $0.2-0.4 \mathrm{~mm}$ in diam.), in having lower hymenium (110-120 $\mu \mathrm{m}$ vs. 140-180 $\mu \mathrm{m}$ high), and in having narrower ascospores $((17-) 20-25(-30) \times(8-) 9-13 \mu \mathrm{m}$ vs. $14-24 \times 10-18 \mu \mathrm{m})$, as well as in containing gyrophoric acid.

Unfortunately diagnoses of the Eastern Asian Hue taxa are missing of some modern characters of and they are in urgent need of revision with the usage modern methods including molecular data set.

Aspicilia geumodoensis is similar to Ionaspis obtecta (Vain.) R. Sant., growing on metal enriched rock, montane, very rare species in Europe, but differs in having plane areoles (vs. areole surface convex), and in having white areoles (vs. deep rust-red), in having immersed apothecia (vs. sessile, constricted at the basis), in the lack of proper margin (vs. proper margin thick, becoming black, often radially striate), in having lower hymenium (110-120 $\mu \mathrm{m}$ vs. to $170 \mu \mathrm{m}$ high, pale yellow, $\mathrm{K}+$ yellow, $\mathrm{N}-$ ), in the lack of brown granules in epihymenium (vs. inspersed with brown granules, not dissolving in $\mathrm{K}$ ), in having larger ascospores $((17-) 20-25(-30) \times(8-) 9-13 \mu \mathrm{m}$ vs. $18-26 \times 10-13$ $\mu \mathrm{m})$, and in having $\mathrm{C}+$ (gyrophoric acid present) thallus.

Other specimens examined: Republic of Korea. Jeollanam-do, Yeosu-si, Nam-myeon, Geumo-do, Simjang-ri, on rock, growing together with Lepraria sp. Lat.: $34^{\circ} 31^{\prime} 19.7^{\prime \prime} \mathrm{N}$; Long.: $127^{\circ} 43^{\prime}$ 52.1" E; Alt: ca 51 m a.s.l. Coll.: Kondratyuk, S. Y. (160417), 10.06.2016 (KoLRI 038562 sub Lepraria); the same locality, growing together with Lepraria sp., (160410), (KoLRI 038555 sub Lepraria).

Biatora ivanpisutii S. Y. Kondr., L. Lőkös et J.-S. Hur, spec. nova (Fig. 4)

Mycobank no.: MB 817969

Similar to Biatora longispora, but differs in much larger and much thicker apothecia, in having well-developed true exciple distinctly underlying all structures of apothecium, in having much darker apothecium disc, and in having 0-1-2-3-septate and much longer ascospores. 
Type: Republic of Korea. Gyeongsangbuk-do, Ulleung-do Island, Ulleung-gun, Ulleung-eup, between Naesujeon and Soekpo waterfall, at a rockwall, on bark, growing together with Biatora ocelliformis, Phaeophyscia rubropulchra and Porina sp. Lat.: 37 31' 19.51" N; Long.: 130 54' 16.03" E; Alt.: 415 m a.s.l. Coll.: Kondratyuk, S. Y. and Lőkös, L. (161743), 09.07.2016 (holotype: KoLRI 039961).

Thallus greyish to greenish grey, somewhat indistinct in places, from very thin to thicker at the apothecia.

Apothecia to $0.8-0.9 \mathrm{~mm}$ in diam. and to $0.3 \mathrm{~mm}$ thick in section, scattered or aggregated in groups, regularly rounded to somewhat irregularly pressed, from slightly semiconvex and marginate at first to more or less convex and almost emarginated, own margin from hyaline or whitish to dirty greyish, disc dark brown to blackish brown; in section true exciple well developed, to 30-40(-80) $\mu \mathrm{m}$ thick in uppermost lateral, to 60-80(-90) $\mu \mathrm{m}$ thick in lower lateral and basal portion, distinctly palisade with well-developed matrix and hyphae lumina of 2-3 $\mu \mathrm{m}$ in diam., mainly hyaline in inner layer, but with dull brownish inclusions in places, usually well underlying all structures of apothecium; hymenium to (50-)60-80 $\mu \mathrm{m}$ high, becoming brownish in places; epihymenium to 10-20 $\mu \mathrm{m}$ thick, bluish or dark/blackish bluish or dark
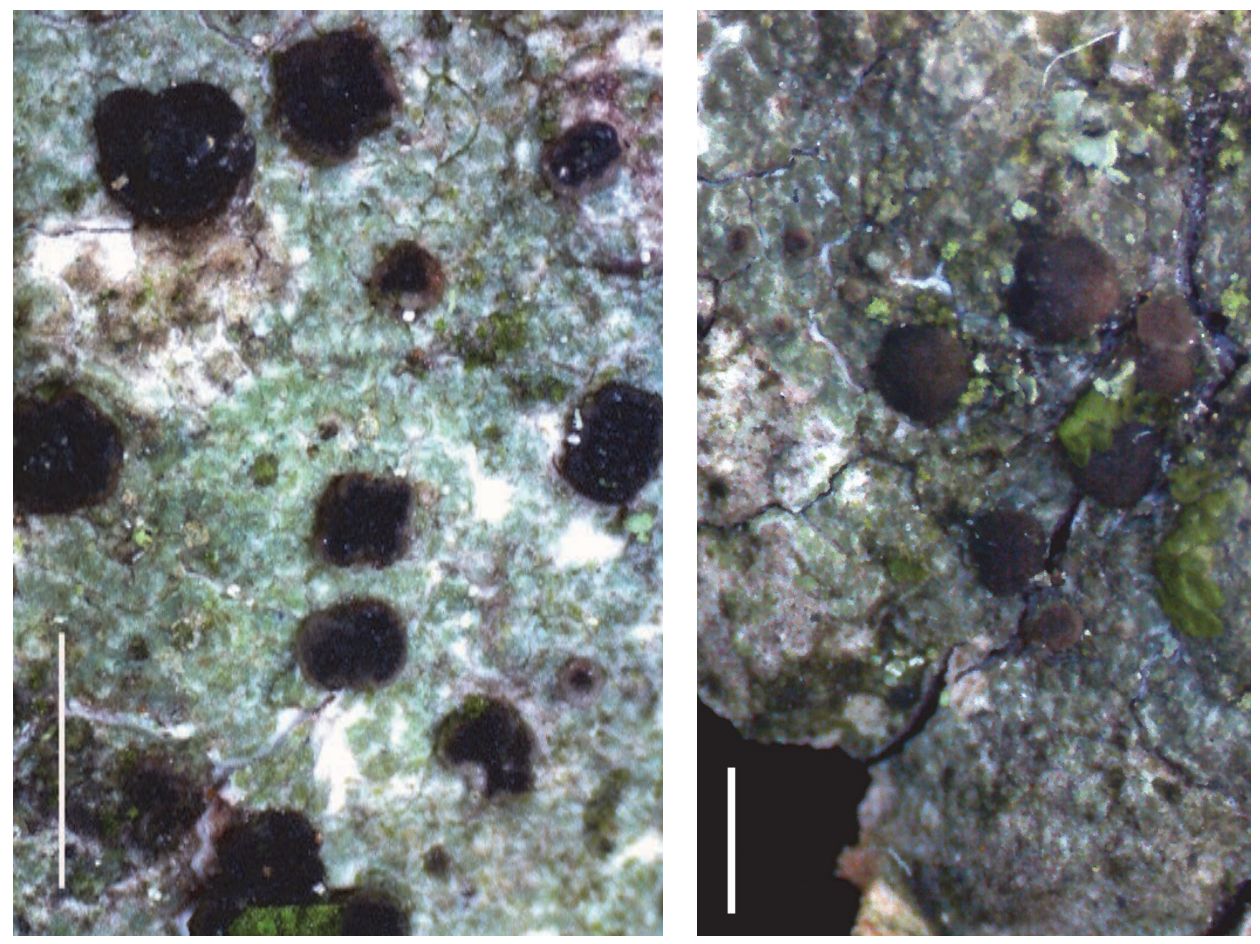

Fig. 4. Biatora ivanpisutii, general habit (holotype). Scale $1 \mathrm{~mm}$ (photo: S. Kondratyuk) 
brown in places, $\mathrm{N}+$ violet-red, $\mathrm{K}$ - or slightly lighter; paraphyses more or less widened gradually to the tips, to 3-4 $\mu \mathrm{m}$ wide, often becoming dull brownish to dark brownish or dirty blackish-bluish towards the tips; subhymenium to $50 \mu \mathrm{m}$ thick, more or less light brownish in lower portion and yellowish or straw to greyish in the upper portion, or dark brown throughout, N- or more yellowish brown, K-; ascospores 0-1-2(-3)-septate, hyaline, fusiform or somewhat cylindrical or slightly widened at one end, sometimes slightly curved, usually one end thinner of the second, (17-)19-25(-29) $\times 2.5-4(-4.5)$ $\mu \mathrm{m}$ in water (and slightly narrower, (18-)20-29 × (2.8-)3-3.5(-4.5) $\mu \mathrm{m}$ in K).

Chemistry. Thallus and apothecia $\mathrm{K}-, \mathrm{N}-, \mathrm{Pd}-$.

Ecology: On bark of tree.

Distribution: So far known only from the type locality in South Korea, Eastern Asia.

Etymology: It is named after the well-known Slovak lichenologist and our friend Ivan Pišút (1935-) (Bratislava, Slovak Republic) in recognition of his contribution to lichenology and especially to our knowledge on diversity of lichen-forming fungi in mountain systems of Eurasia, as well as after external similarity of this taxon to the Eastern Asian taxon Ivanpisutia oxneri.

Taxonomic notes: Biatora ivanpisutii is similar to B. longispora (Degel.) Lendemer et Printzen, but differs in much larger and much thicker apothecia, in having well-developed true exciple distinctly underlying all structures of apothecium, in having much darker apothecium disc, and in having 0-1-2-3-septate and much longer ascospores (see also Kondratyuk et al. 2013a).

A number of specimens were selected with preliminary name as Biatora ivanpisutii from recent collections in the KoLRI. However, most of these specimens are in somewhat intermediate position between Biatora longispora and type collection of B. ivanpisutii. A further, detailed study of this species group including molecular data is planned.

Caloplaca patwolseleyae S. Y. Kondr., U. Jayalal et J.-S. Hur, spec. nova (Fig. 5)

Mycobank no.: MB 817970

Similar to Caloplaca filsonii, but differs in having wider ascospores, and in having much wider ascospore septum, and in different chemistry and distribution.

Type: Republic of Korea. Jeollanam-do, Yeosu-si, Nam-myeon, Geumo-do, Uhak-ri port, on bark. Lat.: $34^{\circ} 30^{\prime} 30.07^{\prime \prime} \mathrm{N}$; Long.: $127^{\circ} 46^{\prime} 13.00^{\prime \prime}$ E; Alt.: $14 \mathrm{~m}$ a.s.l. Coll.: Jayalal, U., Park, J. S., Ryu, J. A. (120610), 27.04.2012 (holotype: KoLRI 015603).

Thallus to 3-4 cm across, crustose, whitish grey to pale grey, with uneven, slightly warted upper surface. In section thallus to $200(-225) \mu \mathrm{m}$ thick (in 

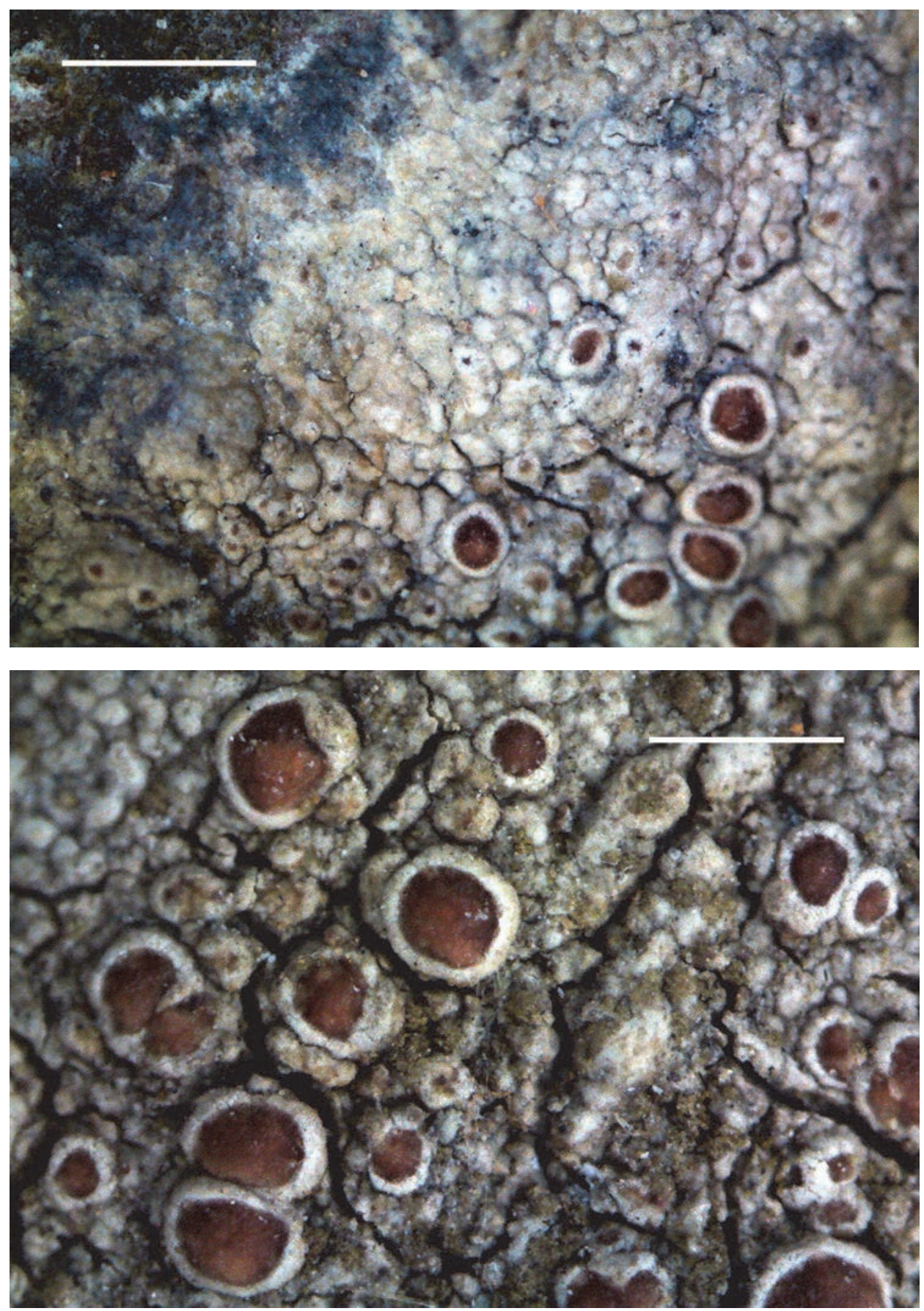

Fig. 5. Caloplaca patwolseleyae (holotype), general habit (scale $1 \mathrm{~mm}$ ) (photo: S. Kondratyuk) 
the centre near apothecium), cortical layer to $20 \mu \mathrm{m}$ thick with very thick cell walls. Algal zone to $80 \mu \mathrm{m}$ thick, algal cells to $10-13 \mu \mathrm{m}$ in diam. Hypothallus black to bluish black, seen in peripheral zone as black line to $0.2-0.5 \mathrm{~mm}$ wide sometimes with whitish to $0.1 \mathrm{~mm}$ wide edge.

Apothecia $0.3-1 \mathrm{~mm}$ in diam., and to $0.5 \mathrm{~mm}$ thick in section, lecanorine, at first scattered, distant and regularly rounded, later sometimes more or less aggregated, pressed and irregular, and semiconvex to convex with uplifted central portion; thalline margin whitish or white greyish, to $0.08-0.1(-0.12)$ $\mathrm{mm}$ wide; disc dull brown to dark brown, at first plane but soon becoming semiconvex with distinctly uplifted central portion.

In section thalline margin to $150 \mu \mathrm{m}$ thick, with very thin cortical layer to 15-20 $\mu \mathrm{m}$ thick; algal zone to 75-120(-130) $\mu \mathrm{m}$ thick in the basis of apothecium; true exciple weakly developed, to $10-15 \mu \mathrm{m}$ thick in lateral and basal portion, paraplectenchymatous; hymenium to $70-80(-100) \mu \mathrm{m}$ high, with slightly yellowish to dull straw yellow epihymenium; paraphysis tips very slightly swollen, to 2-3 $\mu \mathrm{m}$ wide, distinctly becoming yellowish and brownish; subhymenium to 200-250 $\mu$ m thick, hyaline, with coarse small oil droplets to 1 $\mu \mathrm{m}$ in diam.; asci 8-spored; ascospores very narrow, bifusiform, slightly widened at the septum, (12-)13-15(-16) × 4-6 $\mu \mathrm{m}$, septum to $(3.5-) 4-6 \mu \mathrm{m}$ wide. Conidia short bacilliform, 2-2.5 $\times 1 \mu \mathrm{m}$.

Chemistry: Thallus $\mathrm{K}+$ more or less yellowish or brownish yellow.

Ecology: On bark of tree.

Distribution: It is known only from the type locality in South Korea, Eastern Asia.

Etymology: It is named after the well-known British lichenologist Patricia (Pat) A. Wolseley (1939-) (London (BM), UK) for recognition of her contribution in study of lichens of tropical and South Hemisphere regions and her kind support of young lichenologists especially from tropical regions of the Asian continent.

Taxonomic notes: Caloplaca patwolseleyae is characterised by pale grey thallus with lecanorine apothecia with brownish disc (Lecanora subfusca aggr. type apothecia), as well as in having narrow bipolar ascospores with rather wide ascospore septum.

Caloplaca patwolseleyae is similar to C. filsonii Hafellner, S. Y. Kondr. et Kärnefelt, known from bark of Avicennia marina from several localities in Queensland, Australia, but differs in having continuous grey (vs. verrucose whitish grey) thallus, in having only lecanorine (vs. lecanorine then zeorine) apothecia, in having slightly wider ascospores $((12-) 13-15(-16) \times 4-6 \mu \mathrm{m}$ vs. $(11-) 12-15(-16) \times 3-5.5 \mu \mathrm{m})$, and in having much wider ascospore septum ((3.5-)4-6 $\mu \mathrm{m}$ thick vs. 1-2(-5) $\mu \mathrm{m}$ wide), and in different chemistry (vs. thallus $\mathrm{K}+$ red, caloploicin (major), vicanicin (minor), atranorin (minor) and sev- 
eral unknown antraquinones), and distribution (Eastern Asia vs. Australia) (Kondratyuk et al. 2007).

As other Caloplaca species without antraquinones, like Caloplaca patwolseleyae as well as other similar taxa, i.e.: C. brebissonii (Fée) R. Sant. ex Hafellner et Poelt, C. homologa (Nyl.) Hellb., C. ochrolechioides S. Y. Kondr. et Kärnefelt, C. tomnashii S. Y. Kondr., Elix et Kärnefelt, C. subdecadens (Nyl.) Hafellner et Poelt, C. jatolensis Y. Joshi et Upreti, and C. chujaensis S. Y. Kondr., L. Lőkös et J.-S. Hur (see also Fauriea paper in this issue (Kondratyuk et al. 2016b), and which resemble Lecanora species are commonly (and understandably) mistaken for a species of Lecanora, until the ascospores are checked (see Galloway 2007, Joshi et al. 2008, Kondratyuk et al. 2007, 2011, 2015a, 2016a).

It should be mentioned that these species mentioned above (i.e.: C. brebissonii, C. chujaensis, C. homologa, C. filsonii, C. jatolensis, C. patwolseleyae, and C. subdecadens) should be added to the key of Caloplaca species with brown discs and with a lecanorine margin so that resemble species of the Lecanora subfusca aggr. recently proposed by Aptroot and Cáceres (2016). Unfortunately all taxa published much earlier were not included in the key of Aptroot and Cáceres.

\section{Catillaria ulleungdoensis S. Y. Kondr., L. Lőkös et J.-S. Hur, spec. nova} (Figs 6-7)

Mycobank no.: MB 817971

Similar to Catillaria chalybeia, but differs in having less developed and not areolate thallus, in having usually smaller apothecia, in having $\mathrm{N}$-hymenium and exciple, in having narrower hymenium, as well as in having shorter ascospores.

Type: Republic of Korea. Gyeongsangbuk-do, Ulleung-do Island, Ulleung-gun, Bukmyeon, Na-ri, along the coast road (Ulleungsunhwan-ro, Nr. 926), close to Cheonbu Harbour, on siliceous rocks. Lat.: 37 32' 09.12" N; Long.: 130 51' 45.28" E; Alt.: 15 m a.s.1. Coll.: Kondratyuk, S. Y. and Lőkös, L. (161830), 10.07.2016 (holotype: KoLRI 040055), the same locality, (161828), (isotype: KoLRI 040053).

Thallus to $2 \mathrm{~cm}$ across or more, weakly developed or indistinct, mainly from very thin in peripheral zone and to somewhat thicker and cracked (but not areolate), with small irregular portions to $0.1-0.3 \mathrm{~mm}$ across (seen only at the highest magnification, above $\times 100$ ); dark greyish or dull brownish grey. Hypothallus indistinct or with somewhat shiny line to $0.5 \mathrm{~mm}$ wide in peripheral zone.

Apothecia to $0.15-0.3(-0.55) \mathrm{mm}$ in diam., and to $0.12-0.13(-0.18) \mathrm{mm}$ thick in section, lecideine, mostly flat; in section true exciple to (15-)50-70 $(-150) \mu \mathrm{m}$ thick in the uppermost lateral portion, to $20-30 \mu \mathrm{m}$ thick in low- 
er lateral portion, and to $40-80 \mu \mathrm{m}$ thick in basal portion (better seen in $\mathrm{K}$ ), black or black-brown throughout; hymenium to 35-40 $\mu \mathrm{m}$ high; epihymenium dark brownish or blackish, in $\mathrm{K}$ - or $\mathrm{K}+$ intensifying black brownish; paraphysis tips with distinct black cups, very variable in shape, 3-6(-7) $\mu \mathrm{m}$ wide or sometimes to 7-10 $\mu \mathrm{m}$ wide if paraphysis tips curved; subhymenium (30-)40-70 $\mu \mathrm{m}$ thick, more or less dark greyish or blackish or dark brown to blackish brown (better seen in $\mathrm{K}$, in K distinctly brown); asci of Catillaria-type; ascospores hyaline, 1-septate, narrowly ellipsoid, in $\mathrm{K}$ better seen constriction at the septum, $(6-) 7-9(-10) \times(2-) 2.2-2.5(-3.8) \mu \mathrm{m}$. Pycnidia not seen.

Chemistry: Epihymenium and outermost layer of true exciple $\mathrm{N}-$, green $\mathrm{N}+$ pigment absent, epihymenium and exciple $\mathrm{K}-$ or + intensifying blackbrown. Chemistry not examined.

Ecology: On siliceous rocks.

Distribution: Probably rather common species in coastal zone of Eastern Asia, while so far known only from scattered localities in South Korea, Eastern Asia.

It should be emphasised that previous records of both Catillaria atomarioides and $C$. chalybeia should be revised and compared with the new taxon described here.

Etymology: It is named after the type locality, i.e. Ulleung-do Island in South Korea, Eastern Asia.

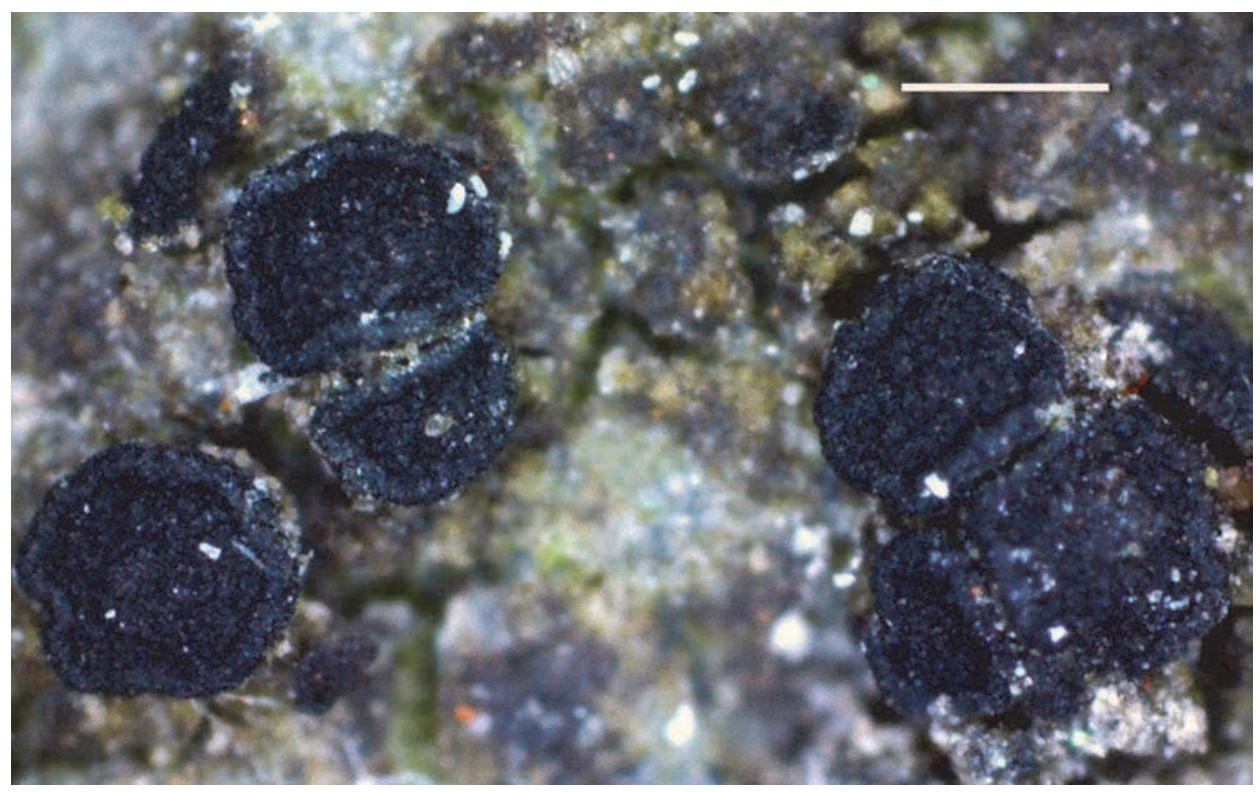

Fig. 6. Catillaria ulleungdoensis, general habit (holotype). Scale $0.5 \mathrm{~mm}$ (photo: S. Kondratyuk) 
Taxonomic notes: After having more or less large apothecia (from 0.2 to $0.5 \mathrm{~mm}$ in diam./across), after having dark brown true exciple throughout, and after having dark brown hypothecium Catillaria ulleungdoensis is similar to $C$. chalybeia (Borrer) A. Massal., growing on a wide range of slightly base-rich or nutrient-enriched siliceous rocks (incl. sea-shore), rare on highly calcareous substrata, occasionally on dust-impregnated timberwork and tree trunk, throughout in Europe, Macaronesia, North and South America, Asia, Africa and Australia, but differs in having less developed and not areolate thallus (vs. distinctly areolate to verruculose-areolate, areoles $0.1-0.4 \mathrm{~mm}$ in diam.), in having usually smaller apothecia $(0.15-0.3(-55) \mathrm{mm}$ vs. $0.2-0.5(-1) \mathrm{mm}$ in diam.), in having $\mathrm{N}-$ (vs. $\mathrm{N}+$ purple red) hymenium and exciple, in having narrower hymenium (to 35-40 $\mu \mathrm{m}$ vs. $40-60 \mu \mathrm{m}$ high), as well as in the lack of green pigment in epihymenium, hymenium and own margin $\mathrm{N}+$ purple-red, as well as in having shorter ascospores $((6-) 7-9(-10) \times(2-) 2.2-2.5(-3.8) \mu \mathrm{m}$ vs. $(7.5-) 9-12(-15) \times 2.5-4 \mu \mathrm{m})$.

Catillaria ulleungdoensis is similar to C. atomarioides (Müll. Arg.) H. Kilias, growing on hard siliceous rocks in Europe, Macaronesia, South Africa, but differs from the latter species in having larger apothecia $(0.15-0.3(-0.55) \mathrm{mm}$ vs. $0.1-0.2 \mathrm{~mm}$ in diam.), in having brown-black (vs. green-black) exciple, in having dark brown hypothallus (vs. colourless), while ascospores are almost the same $((6-) 7-9(-10) \times(2-) 2.2-2.5(-3.8) \mu \mathrm{m}$ vs. $7-10 \times 2.3-3.5 \mu \mathrm{m})$. It should be emphasised that all previous records of Catillaria atomarioides from South Korea (Aptroot and Moon 2014, Kondratyuk et al. 2015a, 2016a) may belong to this taxon.

Catillaria ulleungdoensis is similar to C. subviridis (Nyl.) Zahlbr., growing on nutrient-enriched (e.g. by birds) rocks, in submesic supralitoral zone with Verrucaria maura in Europe and North America, but differs in having black
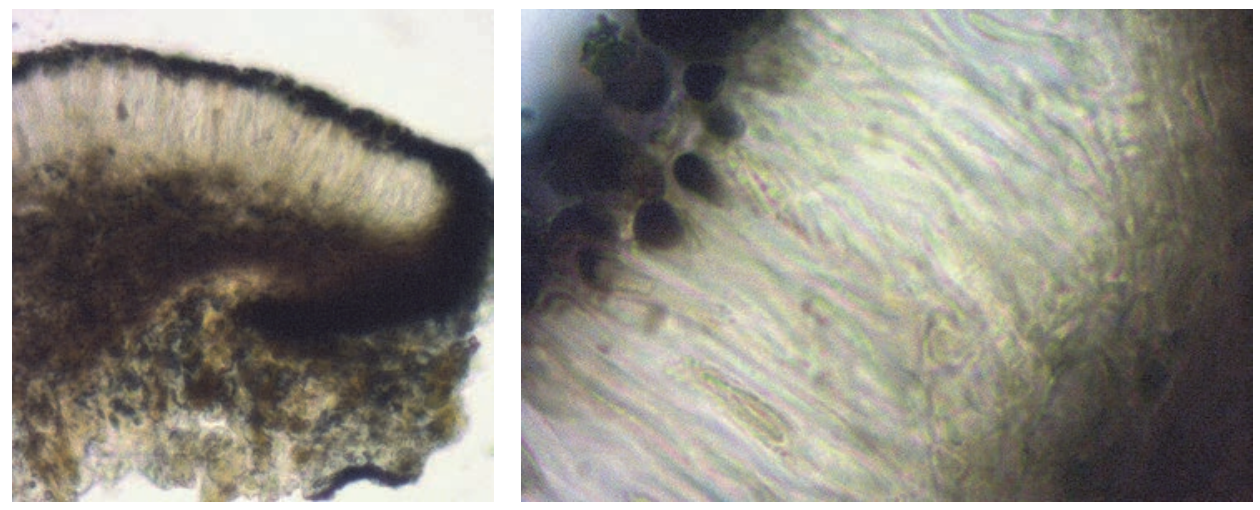

Fig. 7. Catillaria ulleungdoensis (holotype), section of apothecia (left) and paraphyse tips (right) (photo: S. Kondratyuk) 
true exciple throughout (vs. true exciple dark brown only at outer edge and more or less colourless in inner portion), and in having smaller and especially narrower ascospores ((6-)7-9(-10) × (2-)2.2-2.5(-3.8) $\mu \mathrm{m}$ vs. 10-16 × 4.5-6 $\mu \mathrm{m})$.

Other specimens examined: Republic of Korea. Gyeongsangbuk-do, Ulleung-gun, Ulleung-eup, Dodong-ri, Dodong Port, on rock, growing together with Caloplaca sp. 7. Lat.: $37^{\circ} 28^{\prime} 59.9^{\prime \prime}$ N; Long.: $130^{\circ} 54^{\prime} 40.7^{\prime \prime}$ E; Alt. 20 m a.s.l. Coll.: Kondratyuk, S. Y. and Lőkös, L. (162014), 11.07.2016 (KoLRI 040252 sub Catillaria). - Jeollabuk-do, Gunsan-si, Okdo-myeon, Sinsi-do. Lat.: $35^{\circ} 49^{\prime}$ 08.8” N; Long.: 126 27' 55.8” E; Alt.: $19 \mathrm{~m}$ a.s.l. Coll.: [unmentioned] (110820), 22.08.2011 (KoLRI 013829 sub Pertusaria subobductans). - Jeju-do, Jeju-si, Chujado, Chuja-myeon, Yecho-ri, Road of Mt Sindea observatory, on rock, growing together with Caloplaca cf. flavorubescens, and Fuscidea coreana. Lat.: 33 57' 09.9' N; Long.: $126^{\circ} 20^{\prime}$ 13.08" E; Alt.: 56 m a.s.l. Coll.: Joshi, Y., So, J. [site 9] (141038), 21.06.2014 (KoLRI 023592 sub Caloplaca cf. flavorubescens). - Jeju-do, Seogwipo-si, Seongsan-eup, Goseong-ri, Seopjicoji, on rock, growing together with various species of Rinodina and Psorotichia. Lat.: $33^{\circ} 19^{\prime}$ 21.0" N; Long.: 126 50’ 49.03" E. Alt.: 69 m alt. Coll.: Halda, J. P. [site 2] (140432), 19.06.2014 (KoLRI 022829 sub Rinodina).

Coenogonium agonimioides J. P. Halda, S.-O. Oh et J.-S. Hur, spec. nova (Fig. 8)

Mycobank no.: MB 817972

Coenogonium agonimioides differs in having greenish grey coralloid thallus and simple fusiform ascospores $(12 \times 2 \mu \mathrm{m})$. The closest relative Coenogonium isidiatum differs with cylindrical to coralloid isidia formed by thallus outgrowths and also with wider ascospores.

Type: Republic of Korea. Jeju-do province, Seogwipo-si, shaded basaltic rock on the bank of the river. Lat.: $33^{\circ} 18^{\prime}$ 01.36" N; Long.: 126 34' 37" E; Alt.: $303 \mathrm{~m}$ a.s.l. Coll.: Halda, J. P., Oh, S.-O., Liu, D. and Park, C.-H. (152600) 18 August 2015 (holotype: KoLRI 036822); the same locality, (152619) (isotype: KoLRI 036841).

Thallus saxicolous, pale grey green, fragile, composed from minutely coralloid to deeply dissected, branched squamules, resembling richly branched, coralloid isidia, easily detached from stone surface, 30-50 $\mu \mathrm{m}$ in diam. and to $350 \mu \mathrm{m}$ tall, corticate, with a shiny surface when dry; and with white hyphal hairs of $30-50 \times 4-6 \mu \mathrm{m}$ on the lower side of squamules. Photobiont Trentepohlia, cells 5-12 $\mathrm{\mu m}$ in diam.

Apothecia sessile with strongly constricted base, biatorine, rounded, rarely slightly irregular in outline, loosely attached to the thallus, $0.3-1.2 \mathrm{~mm}$ in diam., 180-250 $\mu \mathrm{m}$ high, abundant, at first barrel-shaped, but soon becoming flat, with waxy-orange disc and whitish margin. Exciple well developed, 75-125 $\mu \mathrm{m}$, paraplectenchymatous with radiating cell rows of cellular lumina 4-7(-9) $\mu \mathrm{m}$ wide and to $12 \mu \mathrm{m}$ long. Hymenium 25-40 $\mu \mathrm{m}$ high, colourless. 

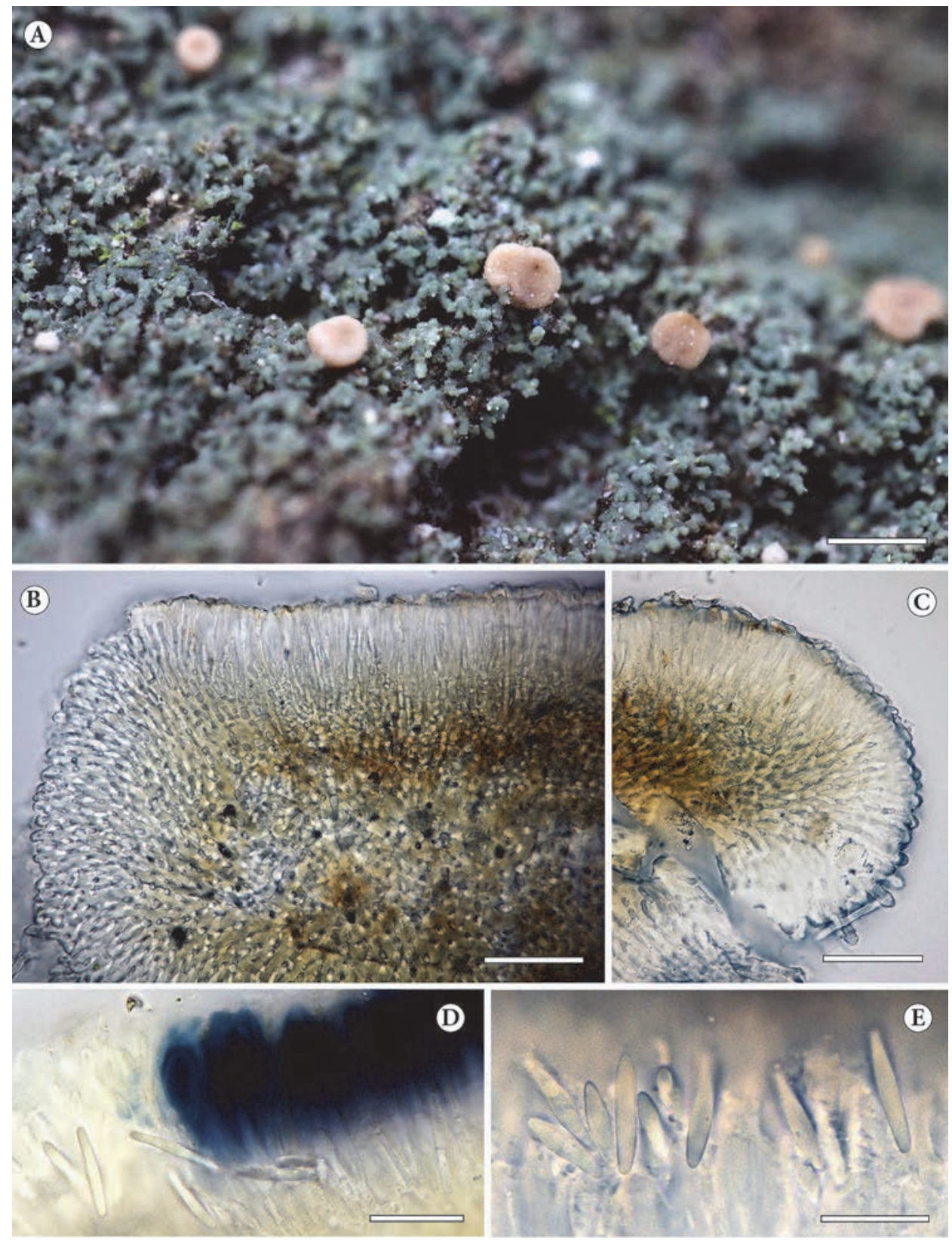

Fig. 8. Coenogonium agonimioides (KoLRI 036822, holotype), A. thallus with ascomata; B, cross-section of apothecium; C, details of exciplulum; D. mature ascospores with asci (mounted in Lugol); E. details of ascospores (mounted in water); Scales: A - $1 \mathrm{~mm}, \mathrm{~B}, \mathrm{C}-$ $50 \mu \mathrm{m}$, D, E. $-10 \mu \mathrm{m}$ (photo: J. P. Halda) 
Epithecium colourless, $\mathrm{K}-$. Hypothecium colourless to pale brown in the centre; paraphyses $1.5 \mu \mathrm{m}$ wide, septate, unbranched to rarely branched, sometimes swollen on apices, apices $2-3 \mu \mathrm{m}$ wide. Asci 8-spored, Catillaria-type, 20-25 × 6-8 $\mu \mathrm{m}$. Ascospores (9-)11-14(-15) × (1.5-) $2(-2.5) \mu \mathrm{m}(\times=12.2 \times 1.7$ $\mu \mathrm{m} ; \mathrm{SD} 1.3 ; 0.3 \mu \mathrm{m} ; \mathrm{n}=50 ; 1 / \mathrm{w}$ ratio $=7.2)$, simple, acicular to fusiform. Pycnidia not observed.

Chemistry: Thallus and ascomata $\mathrm{K}_{-}, \mathrm{C}_{-}, \mathrm{KC}-, \mathrm{P}-, \mathrm{UV}-$. TLC: no substances detected.

Ecology: The species was found growing on acidic rocks (basalt) in shaded habitat along stream protected by forest together with Agonimia pacifica, Coenogonium lueckingii, Flakea papillata, Porina curnowii, P. eminentior, P. leptalea, P. mastoidea, Strigula nipponica, Verrucaria aethiobola and Willeya iwatsukii.

Distribution: So far known from the type locality in Seogwipo, Jeju Island, South Korea.

Etymology: Species epithet "agonimioides" refers to the coralloid arrangement of the thallus branches like in Agonimia species.

Taxonomic notes: Coenogonium agonimioides, a new saxicolous species characterised by a greenish grey, coralloid thallus and simple, fusiform ascospores, was found during a field trip in Jeju Island (South Korea) in August 2015.

The lichen genus Coenogonium is represented by more than 80 species worldwide (Rivas Plata et al. 2006, Ferraro and Michlig 2013). Coenogonium, which is the only genus in the family Coenogoniaceae (Stizenberger 1862), is characterised by a crustose or filamentous thallus with a trentepohlioid photobiont, biatorine (rarely zeorine), yellow to orange or brown apothecia with paraplectenchymatous excipulum, sometimes with pilose margins, partially amyloid hymenium, thin-walled, unitunicate asci, and generally small, simple to 1-septate ascospores (Rivas-Plata et al. 2006, Lücking 2008).

The delicate, richly branched, coralloid "isidia" like thallus and habitat ecology distinguish Coenogonium agonimioides from other relatives. When sterile, C. agonimioides most easily confused with sterile, isidiose morphs of $A$. cavernicola (Kondratyuk et al. 2015a) or A. koreana (Kashiwadani et al. 2002). Corticolous C. isidiatum (Thor and Vězda 1984, Rivas Plata et al. 2006) differs with cylindrical to coralloid isidia formed by thallus outgrowths and also with ascospores (1-septate, 9-14×3-4 $\mu \mathrm{m}$ ). C. isidiigerum (Lücking 1999, Rivas Plata et al. 2006) forms thin, epiphyllous thallus often dissolved in discoid isidia on whitish stalk. Epiphytic C. isidiosum (Breuss 2002, Rivas Plata et al. 2006) is easily distinguish by small apothecia ( $0.5 \mathrm{~mm}$ in diam.), taller hymenium (50-60 $\mu \mathrm{m}$ vs. $25-40 \mu \mathrm{m}$ in C. agonimioides) and isidia with swollen apices. Saxicolous C. lueckingii described from Jeju Island (Joshi et al. 2015) lacks isidia and forms continuous crustose thallus with white prothallus. Corticolous C. kawa- 
nae (Harada and Vězda 1997, Rivas Plata et al. 2006) from Japan forms thin to filmy thallus without isidia, smaller gyalectoid apothecia $(0.25-0.5 \mathrm{~mm})$ and 1-septate ascospores (10-14 × 4-5 $\mu \mathrm{m})$. C. luteum also known from Korea differs with thin, evanescent thallus without isidia, but with whitish conidia.

\section{Gyalidea austrocoreana S. Y. Kondr., L. Lőkös et J.-S. Hur, spec. nova} (Fig. 9)

Mycobank no.: MB 817973

Similar to Gyalidea testacea, but differs in having dark apothecia with black true exciple, in having dark blue hymenium and dark brown subhymenium, in having much thicker and more uplifted above substrate level apothecia, in having (1-2)-septate and longer ascospores.

Type: Republic of Korea. Jeollanam-do Prov., Goheung-gun Co., Bongnae-myeon, Queinaro-do (Wenaro) Island, Mt Bongra, on siliceous rocks, growing together with Porpidia albocaerulescens, Melanophloea coreana, Scoliciosporum jasonhurii, Stereocaulon, Acarospora, and Ionaspis. Lat.: $34^{\circ} 27^{\prime} 2.76^{\prime \prime} \mathrm{N}$; Long.: $127^{\circ} 30^{\prime} 08.16^{\prime \prime} \mathrm{E}$; Alt.: $231 \mathrm{~m}$ a.s.l. Coll.: Wang, X. Y. and Ryu, J. A. (110960), 24.10.2011 (holotype: KoLRI 013936 sub Porpidia albocoerulescens).

Thallus crustose, well developed from very thin in peripheral zone to rather thick in the centre, distinctly verruculose, areolated to continuous with wrinkled or verruculose surface; areoles $0.2-0.3 \mathrm{~mm}$ in diam., early becoming semiconvex to very convex, somewhat distant at initial stages, but soon becoming densely aggregated and forming thick almost continuous thallus, whitish or whitish greyish, with bluish-whitish or greenish-whitish or greenish greyish spots. Hypothallus bluish or bluish black, often as line to $0.25-0.5$ $\mathrm{mm}$ wide around thallus usually well distinctly observed.

Apothecia $0.5-0.85(-1) \mathrm{mm}$ in diam., and to $0.3 \mathrm{~mm}$ thick in section, distant and solitary or often aggregated in small clusters or groups; lecideine, black with bluish tinge or bluish black with somewhat whitish underside; in section true exciple to $30 \mu \mathrm{m}$ thick in the uppermost lateral portion and to $50-70 \mu \mathrm{m}$ thick in lower lateral portion, and to $80-120$ (-200 or more if stipe present) $\mu \mathrm{m}$ in the basal portion, black throughout with somewhat yellowish outermost layer to $10 \mu \mathrm{m}$ thick (in basal portion to $30 \mu \mathrm{m}$ thick); hymenium to 60-70 $\mu \mathrm{m}$ thick, dark bluish, epihymenium not differentiated; subhymenium to $20 \mu \mathrm{m}$ thick, dark bluish or bluish black; asci of Gyalidea-type, 8-spored, often with 1-septate and 3-septate in the same ascus; ascospores (1-2-)3-septate, with distinct halo, 15-20 × (3.5-)3.8-4.5(-5) $\mu \mathrm{m}$.

Ecology: On siliceous rocks. 
Distribution: So far known only from the type locality in South Korea, Eastern Asia.

Etymology: It is named after country, South Korea, where type material was collected.

Taxonomic notes: From all species of the genus Gyalidea it differs in having dark bluish hymenium layer and narrow ascospores with halo.

Gyalidea austrocoreana is similar to G. testacea Vězda et Poelt known from Nepal, after having ascomata $0.6-0.8 \mathrm{~mm}$ in diam., and 1-3-septate, halonate ascospores, but differs in having dark apothecia (vs. light brown), in having apothecia with black (vs. colourless) true exciple, in having dark blue (vs. colourless) hymenium, in having dark brown subhymenium (vs. colourless), in having much thicker and more uplifted (above substrate level) apothecia, in having (1-2)-septate (vs. 1- or 3-septate) and longer ascospores (15-20 × (3.5-)3.8-4.5(-5) $\mu \mathrm{m}$ vs. 12-16 × 4-5 $\mu \mathrm{m})$.
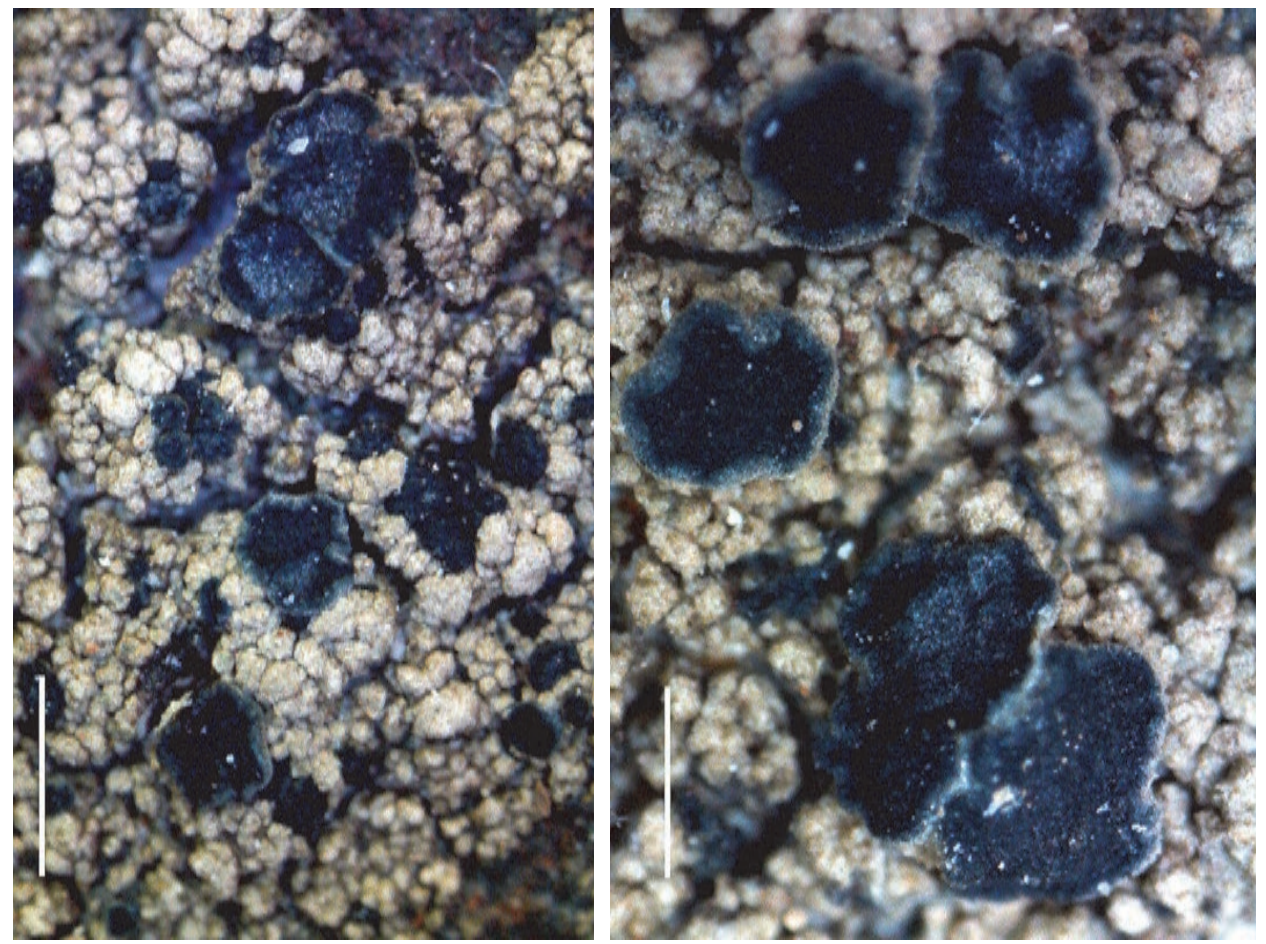

Fig. 9. Gyalidea austrocoreana, general habit (holotype). Scale $1 \mathrm{~mm}$ (left, $0.5 \mathrm{~mm}$ (right) (photo: S. Kondratyuk) 
Gyalidea ropalosporoides S. Y. Kondr., L. Lőkös et J.-S. Hur, spec. nova (Fig. 10)

Mycobank no.: MB 817974

Similar to Gyalidea hyalinescens, but differs in having much thicker and often becoming convex apothecia, in having dark or blackish own margin, in having blackish brown or dark brown disc, in having lower hymenium, in having dark, black or black-bluish exciple with thin hyaline/colourless outer layer, in having narrower and longer ascospores usually with one end distinctly attenuated.

Type: Republic of Korea. Gyeongsangbuk-do, Ulleung-do Island, Ulleung-gun, Ulleung-eup, Jeodong-ri, on rock wall along path to Bongrae waterfall. Lat.: $37^{\circ} 29^{\prime} 52.10^{\prime \prime} \mathrm{N}$; Long.: 130 53' 19.72" E; Alt.: 285 m a.s.l. Coll.: Kondratyuk, S. Y. and Lőkös, L. (161546), 09.07.2016 (holotype: KoLRI 039764).

Thallus crustose, very thin, often cracked together with substrate surface (Fig. 10), to badly developed or indistinct.

Apothecia rather large, $0.9-1.2 \mathrm{~mm}$ in diam., and very thick, to $0.2-0.45$ $(-0.5) \mathrm{mm}$ thick in section, when convex at overmature; at first with welldeveloped and well distinct uplifting level of disc own margin, dark brownish black to black, concolorous with disc; in section exciple to (30-)50-75 $\mu \mathrm{m}$ thick in the uppermost lateral portion, to $70-100 \mu \mathrm{m}$ thick in the lower lateral portion and to $75-150 \mu \mathrm{m}$ thick in basal portion, bluish black or black in inner portions while outer layer to (10-)15-20 $\mu \mathrm{m}$ thick (especially in lateral portion) hyaline or transparent to lightly brownish or violetish black, palisade with well-developed matrix and separate hyphae to 5-6 $\mu \mathrm{m}$ wide, and hyphae lumina of 2(-3) $\mu \mathrm{m}$ seen; epinecral layer to 3-7 $\mu \mathrm{m}$ thick in lateral portion and on underside sometimes observed, hyaline hyphae to $15-25 \mu \mathrm{m}$ long and 2-2.5 $\mu \mathrm{m}$ wide sometimes at outer layer of true exciple observed; sometimes stipe or basis of apothecium to 100(-150) $\mu \mathrm{m}$ thick, blackish, concolorous with true exciple often observed; hymenium to (50-)60-70(-80) $\mu \mathrm{m}$ high, hyaline but sometimes with bluish portions vertically orientated; epihymenium indistinct, the same hyaline or bluish as hymenium; paraphyses slightly swollen towards the tips to 3-4(-5) $\mu \mathrm{m}$ wide; asci 75-85 × 10-12 $\mu \mathrm{m}$, 8-spored; subhymenium 20-25(-40) $\mu$ m thick, somewhat brownish to reddish or violetish brown; ascospores (0-)1-3(-4)-septate, hyaline, elongated ellipsoid to fusiform, slightly widened in the middle with more or less attenuated but rounded ends, sometimes one of the middle cell is the widest and one end thinner (tail-like), slightly constricted at septum, (16-)22-29(-30) × 4-5.5(-6.5) $\mu \mathrm{m}$. Pycnidia not seen.

Chemistry: Chemistry not examined.

Ecology: On shaded, siliceous rocks. 
Distribution: So far known only from scattered localities in South Korea, Eastern Asia.

Etymology: It is named after similarity with Ropalospora chirisanensis S. Y. Kondr., L. Lőkös et J.-S. Hur recently described from South Korea, Eastern Asia.

Taxonomic notes: Gyalidea ropalosporoides is similar to G. hyalinescens (Nyl.) Vězda in having well-developed own margin at first and concave or flat disc, as well as in having large apothecia, but differs in having much thicker and often becoming convex apothecia $(0.2-0.45(-0.5) \mathrm{mm}$ vs. $0.2-0.3$ mm thick, only concave later flat), in having dark or blackish own margin (vs. waxy yellowish to yellow-brown), in having blackish brown or dark brown disc (vs. light yellow-brown to light brown), in having lower hymenium (vs. 90-120 $\mu \mathrm{m}$ high), in having somewhat thinner true exciple in the uppermost lateral portion (50-75 $\mu \mathrm{m}$ in the uppermost and to $100 \mu \mathrm{m}$ thick in lower lateral portion vs. 60-120 $\mu \mathrm{m}$ thick in lateral portion); in having dark, black or black-bluish exciple with thin hyaline (transparent) outer layer (vs. colourless or slightly yellowish, where outermost layer yellow to olive yellow), in having wider range of ascospore sizes seem to be narrower and longer and usually with one end distinctly attenuated (22-29 × 4-5.5 $\mu \mathrm{m}$ vs. $16-24 \times 5-6 \mu \mathrm{m})$, as well as in the lack of pruina in young apothecia.

Gyalidea ropalosporoides is similar to Ropalospora chirisanensis S. Y. Kondr., L. Lőkös et J.-S. Hur recently described from South Korea, Eastern Asia (Kond-

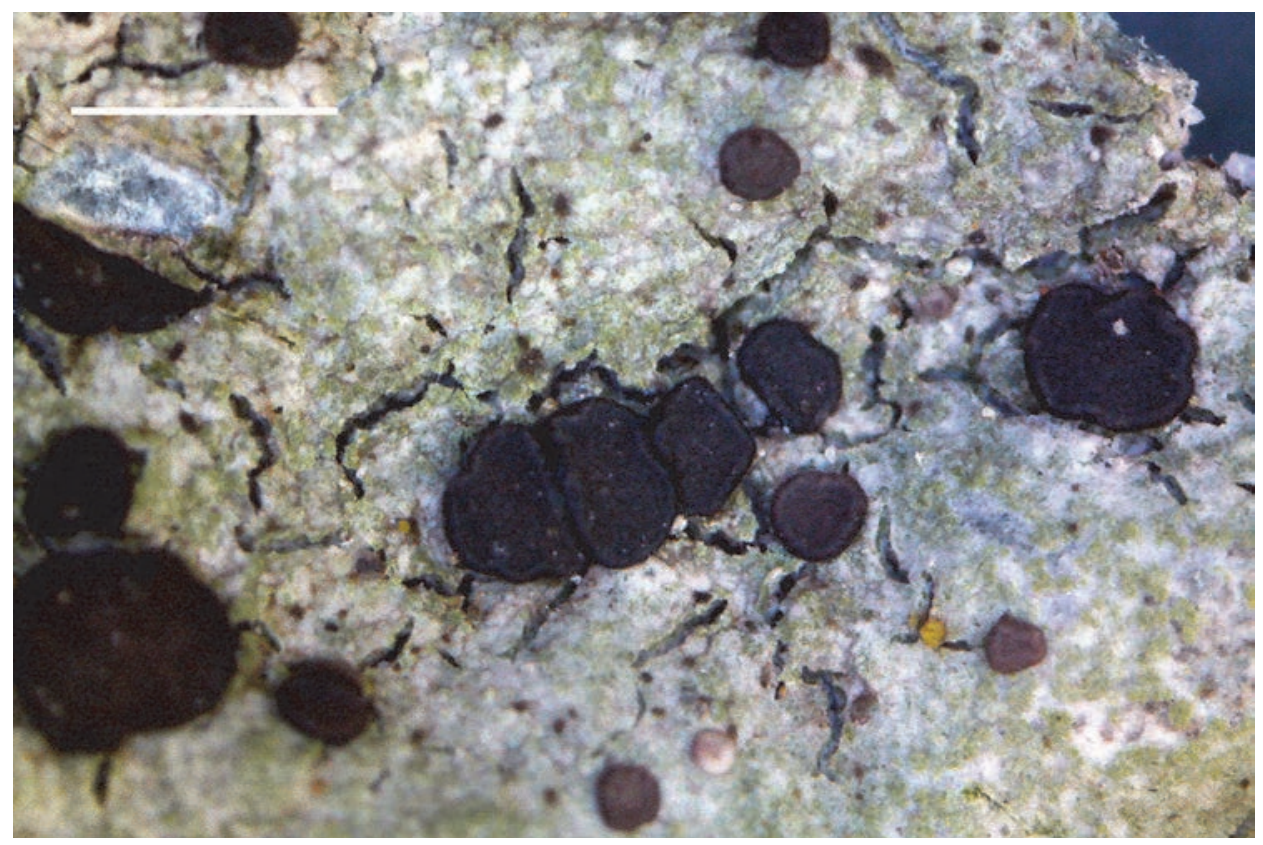

Fig. 10. Gyalidea ropalosporoides, general habit (holotype). Scale $1 \mathrm{~mm}$ (photo: S. Kondratyuk) 
ratyuk et al. 2016a) after having black, lecideine apothecia from plane with very thick own margin to convex and emarginated, after having black, brownish or bluish black true exciple in inner portions and hyaline or colourless in outermost layer, and after having hyaline hymenium and not differentiated (the same hyaline) epihymenium, but differs in having apothecia closely attached to the substrate (vs. uplifted above the thallus surface), in having darker blackish apothecia (vs. dull greyish brown or brown to dull dark brown), in having distinctly plane or concave apothecium disc at young stages, in having hyaline hyphae projected at outer layer of true exciple, in having palisade true exciple with hyphae lumina of $2(-3) \mu \mathrm{m}$ (vs. scleroplectenchymatous true exciple, hyphae lumina of 1-1.5 $\mu \mathrm{m}$ ), in having darker subhymenium (vs. hyaline), in having Gyalidea-type of asci, in having narrowly ellipsoid to fusiform ascospores (vs. widened at the equatorial portion with distinctly attenuated ends to somewhat rhomboid) and in having somewhat longer ascospores (22$29 \times 4-5.5 \mu \mathrm{m}$ vs. $18-25 \times 4-6 \mu \mathrm{m})$.

Other specimen examined: Republic of Korea. Gyeongsangbuk-do, Ulleung-do Island, Ulleung-gun, Ulleung-eup, between Naesujeon and Soekpo waterfall, near shelter house, on siliceous rocks, growing together with Dimerella aff. lutea and other crustose lichens. Lat.: 37 31'09.53" N; Long.: 130 54' 13.17" E; Alt.: 280 m a.s.1. Coll.: Kondratyuk, S. Y. and Lőkös, L. (161718), 09.07.2016 (KoLRI 039936 sub Dimerella).

\section{Opegrapha briancoppinsii S. Y. Kondr., L. Lőkös et J.-S. Hur, spec. nova} (Fig. 11)

Mycobank no.: MB 817975

Similar to Phaeographa glaucomaria, but differs in having smaller apothecia, in having somewhat rounded aggregations of ascomata, in having narrower ascospores, as well as in having different host.

Type: Republic of Korea. Jeju-do Prov., Cheju-do Island, Jeju-si, Mt Halla, Gwanumsa trail, on rocks. Lat.: $33^{\circ} 25^{\prime} 18.04^{\prime \prime}$ N; Long.: $126^{\circ} 32^{\prime}$ 58.09" E; Alt.: 577 m a.s.l. Coll.: Oh, S.-O., Jayalal, U., Park, A.-S. and Hur, J.-S. (120935), 01.06.2012 (holotype: KoLRI 015965 sub Porpidia albocaerulescens).

Ascomata lichenicolous, black, epruinose, when young, roundish, subspherical, totally immersed in the host thallus and breaking through the host cortex; upper sterile stromatic layer soon breaking along irregular slits giving the ascoma a verruculose appearance, with remnants often remaining on margin and/or upper surface of the ascoma; mature ascomata regularly appearing aggregated in groups reaching to $0.4-0.8(-1) \mathrm{mm}$ diam./across and being immersed into the host thallus, often causing bleaching spots of host thallus to 

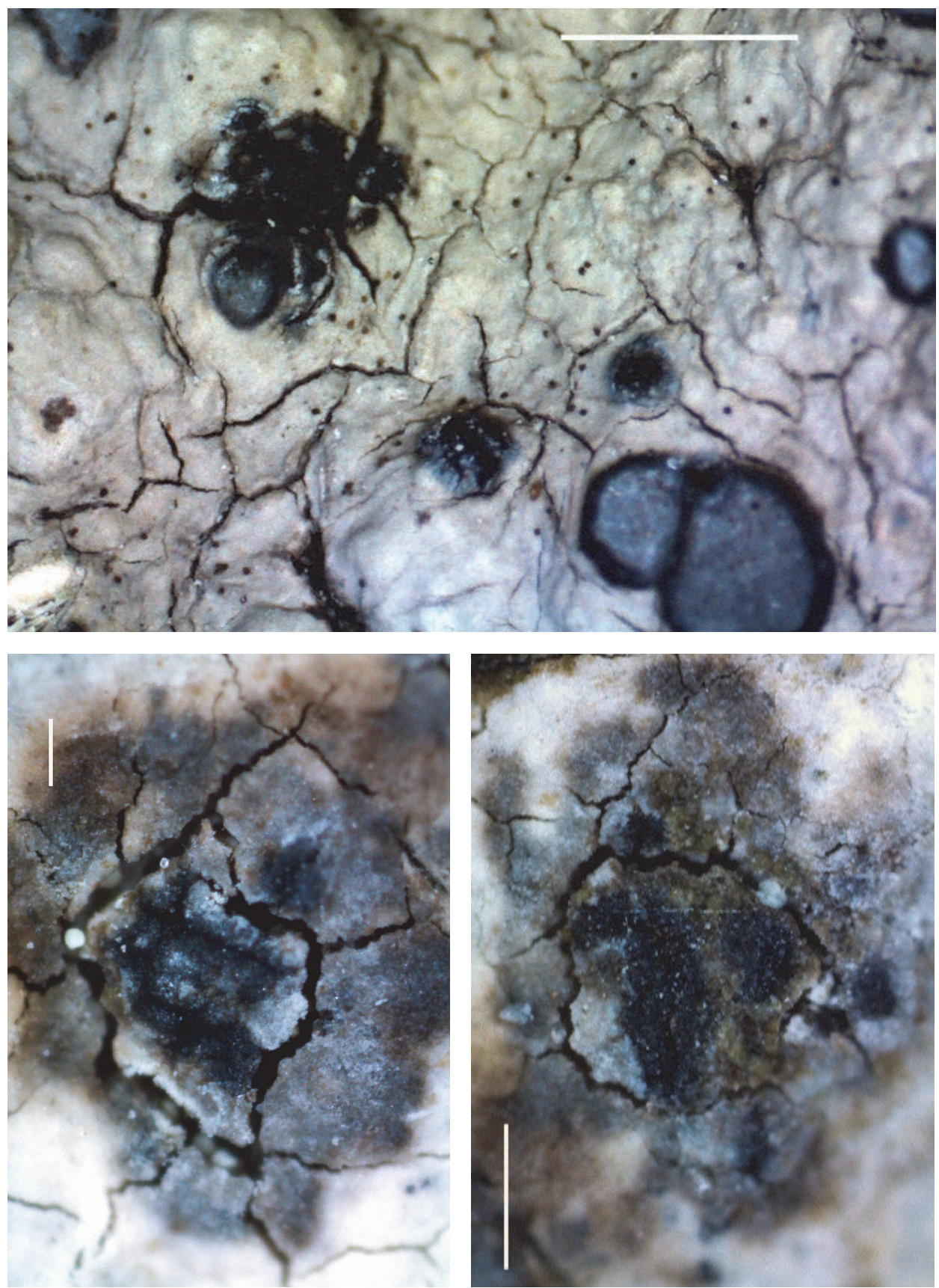

Fig. 11. Opegrapha briancoppinsii (holotype), general habit (KOLRI 004777) (top), enlarged ascomata (bottom). Scale $2 \mathrm{~mm}$ (top), 0.5 (bottom) (photo: S. Kondratyuk) 
$1-1.5 \mathrm{~mm}$ total size, but usually as somewhat greyish zone around ascomata; apothecia mainly slit (not open), exciple laterally and basally very variable in thickness, dark brown, K-; hymenium hyaline, 90-100 $\mu \mathrm{m}$ high; subhymenium hyaline, paraphyses branched and anastomosed, $2-2.5 \mu \mathrm{m}$ wide, apically indistinctly swollen; asci subclavate, $c a 70 \times 18 \mu \mathrm{m}, 8$-spored, often with 1-septate and 3-septate ascospores in the same ascus; ascospores elongate ellipsoid or with one end slightly narrower, (1-2-)3-septate, slightly constricted at the medium septum, hyaline, becoming brown (to blackish-greenish or intensifying greenish in $\mathrm{K}$ ) and distinctly verrucose at maturity, with distinct verrucae to 2-3 $\mu \mathrm{m}$ across (better seen in K), (19-)21-29 × (4-)4.5-6(-7.5) $\mu \mathrm{m}$; brown pigment located on the ascospore wall; ascospores often remain agglutinated together after releasing from asci. Conidiomata and conidia unknown.

Host: Porpidia albocaerulescens (thallus).

Distribution: So far known from scattered localities in South Korea, Eastern Asia.

Etymology: It is named after the well-known British lichenologist Brian J. Coppins (1949-) (Edinburgh (E), UK) for recognition of his contribution to recent knowledge on microlichens especially and who has much contributed to study of the genus Opegrapha s. lat., too.

Taxonomic notes: Opegrapha briancoppinsii is similar to Phaeographa glaucomaria (Nyl.) Hafellner (= Opegrapha glaucomaria (Nyl.) Hafellner), but differs in having smaller apothecia $(0.4-0.8(-1) \mathrm{mm}$ vs. up to $1 \mathrm{~mm}$ in diam.), in having somewhat rounded aggregations of ascomata (vs. sometimes arranged in arcs on the host thallus), in having narrower ascospores ((19-)21-29 $\times(4-) 4.5-$ $6(-7.5) \mu \mathrm{m}$ vs. $21-29 \times 7-9 \mu \mathrm{m}$ ), as well as in having different host (vs. Lecanora rupicola, rarely known from Protoparmelia badia).

Leciographa stigma (Arnold) Rehm known from Porpidia macrocarpa from Bavarian Alps has very small ascomata (to $0.1-0.3 \mathrm{~mm}$ in diam.), very small asci $(30-36 \times 10-12 \mu \mathrm{m})$, and very small 1-3-septate ascospores $(6-10 \times 3-4 \mu \mathrm{m}$ vs. (19-)21-29 × (4-)4.5-6(-7.5) $\mu \mathrm{m}$ in Opegrapha briancoppinsii).

Opegrapha briancoppinsii is similar to O. physciaria (Nyl.) D. Hawksw. et Coppins, but differs in having smaller apothecia to $0.4-0.8(-1) \mathrm{mm}$ in diam./ across (vs. dense clusters to $0.5-4 \mathrm{~mm}$ in diam.) and being immersed into the thallus (vs. uplifted above level of host thallus), and in causing bleaching spots to $1-1.5 \mathrm{~mm}$ total size, but usually as somewhat greyish zone around ascomata observed, in having $\mathrm{K}$ - exciple (vs. K+ brown-red exciple), in having mainly slit (not open) disc, as well as in having higher hymenium (vs. to 45 $\mu \mathrm{m}$ high), and in having much longer ascospores ((19-)21-29 $\times(4-) 4.5-6(-7.5)$ $\mu \mathrm{m}$ vs. (12-)14-17 × (4-)5-6.5 $\mu \mathrm{m})$.

Opegrapha rinodinae Vězda growing on Phaeorrhiza nimbosa and known from Europe (Slovakia and Norway) has almost the same ascospores ((19-) 
21-29 × (4-)4.5-6(-7.5) $\mu \mathrm{m}$ vs. 22-26 × 4-6 $\mu \mathrm{m})$, but differs in having 3-5-septate ascospores and $4-8$-spored asci.

Opegrapha parasitica (A. Massal.) H. Olivier, which has immersed ascomata in Aspicilia calcarea thallus, known from Europe and Australia, differs also in having much shorter 3-septate ascospores $(16-22 \times 6-8 \mu \mathrm{m})$ hyaline at first, becoming brown with age.

After 3-septate ascospores and 8-spored asci material of Opegrapha briancoppinsii may be keyed to Leciographa parvula (Arnold) Sacc., growing on Pertusarias and known from Newfoundland (Canada), to Leciographa furfuracea (Anzi) Rehm known from various not calcium containing saxicolous rocks of Lombardy Alps (Italy, Europe), and to Opegrapha pulvinata Rehm in Lojka, growing on Dermatocarpon miniatum of Europe, North and Central America. However, in contrast to Opegrapha briancoppinsii, Leciographa parvula has $\mathrm{K}+$ reddish brown epihymenium and smaller ascospores (15-18 $\times 4 \mu \mathrm{m}$ vs. (19-) 21-29 × (4-)4.5-6(-7.5) $\mu \mathrm{m})$. Furthermore Leciographa furfuracea differs from Opegrapha briancoppinsii in having very small and much wider ascospores (11$13 \times 6-7 \mu \mathrm{m}$ vs. (19-)21-29 × (4-)4.5-6(-7.5) $\mu \mathrm{m})$, and Opegrapha pulvinata has shorter and wider ascospores (18-25 × 6-9 $\mu \mathrm{m}$ vs. $(19-) 21-29 \times(4-) 4.5-6(-7.5)$ $\mu \mathrm{m})$.

Among lichenicolous fungi having pruinose apothecium disc, but being similar to Opegrapha briancoppinsii, Leciographa weissii Koerb. and L. associata (Norm.) Rehm (= Geltingia associata (Th. Fr.) Alstrup et D. Hawksw.) should be mentioned, too.

Other specimens examined: Republic of Korea. Gangwon-do, Pyeongchang-gun, Daegwalnyeong-myeon, Byeongnae-ri, Odae-san Mts, on rocks. Lat.: $37^{\circ} 45^{\prime} 53.5^{\prime \prime}$ N; Long.: $128^{\circ} 36^{\prime}$ 34.7" E; Alt.: 1,088 m a.s.l. Coll.: Hur, J.-S. (080498), 15.07.2008 (KoLRI 008733 sub Porpidia albocaerulescens). - Jeju-do, Seogwipo-si, Donneako Valley, Wonang Waterfall, on rocks. Lat.: $33^{\circ} 18^{\prime}$ 04.3” N; Long.: 126 34' 53.7" E; Alt.: $330 \mathrm{~m}$ a.s.l. Coll.: Joshi, Y. (140533), 19.06.2014 (KoLRI 022928 sub Porpidia albocaerulescens). - Jeollanam-do, Gwangyang-si, Baegun-san Mts. Lat.: 35 06' 55.3” N; Long.: $127^{\circ}$ 36' 37.0”' E; Alt.: 1,000 m a.s.l. Coll.: [s.n.] (060406), 27.06.2006 (KoLRI 004777 sub Porpidia albocaerulescens).

\section{Opegrapha ulleungdoensis S. Y. Kondr., L. Lőkös et J.-S. Hur, spec. nova} (Fig. 12)

Mycobank no.: MB 817976

Similar to Opegrapha calcarea, but differs in having mainly greyish-brownish thallus, in having mainly seem to be widely gaped disc, in having lower hymenium, in having longer ascospores, and in the lack of lipid-rich cells.

Type: Republic of Korea. Gyeongsangbuk-do, Ulleung-do Island, Ulleung-gun, Bukmyeon, Cheonbu-ri, steep rocky roadside along Buk-myeon coast road (Ulleungsunhwan- 
ro, Nr. 926), on siliceous rocks. Lat.: $37^{\circ} 32^{\prime} 29.14^{\prime \prime}$ N; Long.: $130^{\circ} 54^{\prime} 46.98^{\prime \prime}$ E; Alt.: $10 \mathrm{~m}$ a.s.l. Coll.: Kondratyuk, S. Y. and Lőkös, L. (161299), 07.07.2016 (holotype: KoLRI 039505); the same locality, (161302), (isotype: KoLRI 039508); the same locality growing together with Lepraria, (161284), (isotype: KoLRI 039490 sub Opegrapha); the same locality growing together with Lecanora, (161287), (isotype: KoLRI 039493 sub Opegrapha); the same locality growing together with Lecanora and Agonimia, (161288), (isotype: KoLRI 039494 sub Opegrapha); the same locality growing together with Agonimia, (161293), (isotype: KoLRI 039499 sub Opegrapha); the same locality growing together with Lecanora, (161298), (isotype: KoLRI 039504 sub Opegrapha); the same locality growing together with Lecanora, (161300), (isotype: KoLRI 039506 sub Opegrapha).

Thallus greenish grey or greyish-brownish, continuous, sometimes somewhat indistinct.

Apothecia rather small, $0.5-0.8 \times 0.15-0.25(-0.3) \mathrm{mm}$ wide and to 0.12 $\mathrm{mm}$ thick in section; exciple entire, to $10-12 \mu \mathrm{m}$ wide in the uppermost lateral portion, and to 20-25 $\mu \mathrm{m}$ thick in lower lateral portion, 25-30 $\mu \mathrm{m}$ thick in basal portion, black to black-olivaceous, in K becoming blackish olive; hymenium to $70-80 \mu \mathrm{m}$ high; epihymenium to $15-20 \mu \mathrm{m}$ thick, brownish; subhymenium to 20-30 $\mu \mathrm{m}$ thick, brownish-greenish, sometimes with oil droplets to $4 \mu \mathrm{m}$ in diam.; asci 8-spored, (40-)45-60 $\times 12-18 \mu \mathrm{m}$, with rather thick walls to $3 \mu \mathrm{m}$ thick; ascospores 3 -septate, hyaline while at overmature with blackish grains in episporium, one cell in the middle slightly wider, without constriction at the septum, (16-)19-23 × (3-)4.5-5.5 $\mu \mathrm{m}$. Conidiomata and conidia not observed.

Ecology: On siliceous rocks in supralitoral zone of coastal areas.

Distribution: Known so far from several localities of Ulleung-do Island (South Korea, Eastern Asia), where sometimes rather abundant.

Etymology: It is named after Ulleung-do Island where type material was collected.

Taxonomic notes: Opegrapha ulleungdoensis is similar to O. calcarea Sm., growing on damp, shaded limestone, mortar, bone or base-enriched rock, known from Europe, Macaronesia, N America, Asia and Africa, in having somewhat greenish exciple, epihymenium and subhymenium in K, but differs in having mainly greenish or greyish-brownish thallus (vs. white, grey, pale green-pink or rusty ochraceous), in having mainly seem to be widely gaped disc (owing to rather small length, vs. disc a slit, sometimes partially exposed with age), in having shorter apothecia $(0.5-0.8 \times 0.15-0.25(-0.3) \mathrm{mm}$ vs. $0.6-1.2(-2) \times(0.1-) 0.15-0.3 \mathrm{~mm})$, in having lower hymenium $(70-80 \mu \mathrm{m}$ vs. $80-100 \mu \mathrm{m}$ high), in having longer ascospores ((19-)20-23 × (4-)4.5-5.5 $\mu \mathrm{m}$ vs. $16-20(-24) \times 4-5(-6.5) \mu \mathrm{m}$ ), in lack of lipid-rich cells (vs. often with abundant lipid-rich cells which stain in Sudan Black, 5-10 $\mu \mathrm{m}$ wide).

Opegrapha ulleungdoensis is similar to O. dolomitica (Arnold) Clauzade et $\mathrm{Cl}$. Roux, growing on moist limestone or calcareous schists (especially under 

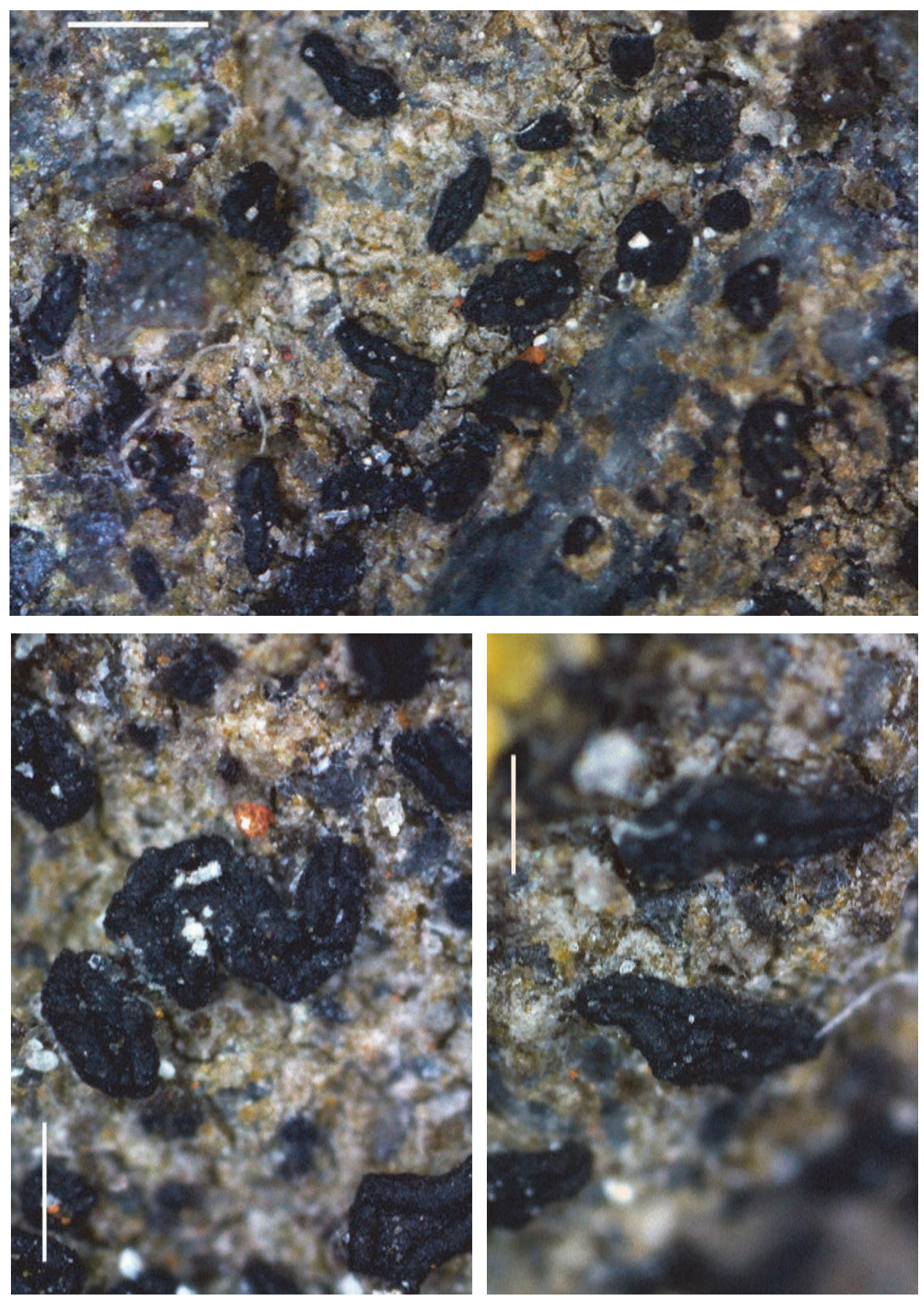

Fig. 12. Opegrapha ulleungdoensis (holotype). Scale $0.5 \mathrm{~mm}$ (photo: S. Kondratyuk) 
overhangs), sides of clints in limestone pavement, mortar or associated baseenriched siliceous rock in Europe, but differs in having grey-brown thallus (vs. creamy white, grey, greenish to brown-red), in having shorter apothecia $(0.5-0.8 \times 0.15-0.25(-0.3) \mathrm{mm}$ vs. $0.5-1.8(-3) \times 0.16-0.25(-0.35) \mathrm{mm})$, in having blackish olive (vs. brown) pigmentation of the apothecial tissues, in having greenish exciple, epihymenium and subhymenium in $\mathrm{K}$, in having lower hymenium $(70-80 \mu \mathrm{m}$ vs. 90-120 $\mu \mathrm{m})$, in having somewhat shorter and narrower ascospores ((19-)20-23 × (4-)4.5-5.5 $\mu \mathrm{m}$ vs. $(20-) 22-26(-31) \times 5-8 \mu \mathrm{m})$, and in the lack of a thin perispore.

The 'KoLRI 034547' specimen (coll. num. 151314) differs in having much narrower ascospores ((15)-19-22 × (2.5-)3-4 $\mu \mathrm{m})$ and may represent a separate taxon. It is included here with some hesitation.

Other specimens examined: Republic of Korea. Gangwon-do, Samcheok-si, Geundeok-myeon, Gongchonhaebyeon-gil, seashore siliceous rocks, growing together with $\mathrm{Ca}$ loplaca sp. Lat.: $37^{\circ} 19^{\prime} 43.68^{\prime \prime}$ N; Long.: 129 $16^{\prime} 12.36^{\prime \prime}$ E; Alt.: 5 m a.s.l. Coll.: Kondratyuk, S. Y. and Lőkös, L. (151314), 11.07.2015 (KoLRI 034547 sub Opegrapha). - Gyeongsangbukdo, Ulleung-do Island, Ulleung-gun, Buk-myeon, Cheonbu-ri, steep rocky roadside along Buk-myeon coast road (Ulleungsunhwan-ro, Nr. 926), on siliceous rocks, growing together with Lecanora. Lat.: $37^{\circ} 32^{\prime}$ 29.14" N; Long.: $130^{\circ} 54^{\prime} 46.98^{\prime \prime}$ E; Alt.: $10 \mathrm{~m}$ a.s.l. Coll.: Kondratyuk, S. Y. and Lőkös, L. (161285), 07.07.2016 (KoLRI 039491 sub Lecanora). - Jeollanam-do, Yeosu-si, Nam-myeon, Geumo-do, Uhak-ri port, on rock. Lat.: $34^{\circ} 30^{\prime} 30.07^{\prime \prime} \mathrm{N}$; Long.: $127^{\circ} 46^{\prime} 13.00^{\prime \prime}$ E; Alt.: $14 \mathrm{~m}$ a.s.l. Coll.: Jayalal, U., Park, J. S. and Ryu, J. A. (120587), 27.04.2012 (KoLRI 015579 sub Opegrapha).

\section{Phyllopsora loekoesii S. Y. Kondr., E. Farkas, S.-O. Oh et J.-S. Hur, spec. nova}

(Fig. 13)

Mycobank no.: MB 817977

Similar to Phyllopsora corallina, but differs in having longer ascospores; in having $P d$-thallus, in having long and abundantly branched isidia, in having narrower cortex, and it the lack of crystals in cortex, in having dull brown apothecia, in the lack of pale to red prothallus, in the lack of atranorin, argopsin, norargopsin, vicanicin, norvicanicin, phyllopsorin, chlorophyllopsorin, parvifoliin, zeorin, in the lack of red pigmented apothecium margin, as well as hypothecium and hymenium.

Type: Republic of Korea. Gyeongsangbuk-do, Ulleung-do Island, Ulleung-gun, Ulleung-eup, between Naesujeon and Soekpo waterfall, at a rock wall, on siliceous rocks. Lat.: $37^{\circ} 31^{\prime} 19.51^{\prime \prime}$ N; Long.: $130^{\circ} 54^{\prime} 16.03^{\prime \prime}$ E; Alt.: 415 m a.s.l. Coll.: Kondratyuk, S. Y. and Lőkös, L. (161759), 09.07.2016 (holotype: KoLRI 039977); the same locality, growing together with Lepraria sp., (161765), (isotype: KoLRI 039983); the same locality, growing together with sterile cyanolichen, (161769), (isotype: KoLRI 039989). 
Thallus crustose, squamulose and crustose at first, but soon becoming bulky and multi-stored of numerous isidious formations, green to dark green with scattered brownish apothecia. Thalline squamules $0.3-0.5 \mathrm{~mm}$ in diam./ across, at first rather distinct, slightly convex, with numerous isidia, but soon completely covered by isidia and indistinct. Isidia more or less cylindrical or with undulating surface, to $0.1-0.15(-0.23) \mathrm{mm}$ wide and to $0.5-0.8(1) \mathrm{mm}$ long, richly ramified, secondary lobules of the same (to $0.1 \mathrm{~mm}$ wide) thickness, total width of the whole isidia with secondary lobules to $0.6-0.8 \mathrm{~mm}$ wide; in section radially built with very narrow cortical layer to $5-7 \mu \mathrm{m}$ thick. Upper surface green to dark green or whitish to slightly brownish-whitish in damaged portions; at large magnification with pimples and separate vertically orientated hyphae to $2.5-5(-7.5) \mu \mathrm{m}$ long. Total width of one single squamule with isidia very indistinct as far they form continuous mass/bulky thallus.

Apothecia $0.4-1 \mathrm{~mm}$ in diam., and to $0.3 \mathrm{~mm}$ thick in section; very variegated in shape and colour, from light to dark brown within the same apothecium, biatorine, from convex at first stage to somewhat plane and with undulating surface; with indistinct somewhat greyish edge/own margin, sometimes whitish to $0.1 \mathrm{~mm}$ wide, distinct at $\times 100$ magnification; and more or less convex light brown to dark brown disc; in section true exciple to 100 $\mu \mathrm{m}$ thick in lateral and basal portions, outer layer hyaline, while inner layers bright yellowish or bright yellow-brownish, with well-developed matrix but separate hyphae to 7-8 $\mu \mathrm{m}$ wide seen with hyphae lumina of $2-3 \mu \mathrm{m}$; hymenium to $50 \mu \mathrm{m}$ thick, yellowish or somewhat hyaline-yellow in comparison with other tissue; subhymenium to $80 \mu \mathrm{m}$ thick, somewhat indistinct in lower portion, in lower portion dull orange or dull orange-brownish (the darkest portion of apothecium section); ascospores narrowly ellipsoid to cylindrical or fusiform, where only slightly widened in the middle portion, simple, hyaline, $(11-) 13-16 \times 2-2.8(-3.5) \mu \mathrm{m}$.

Chemistry: Apothecium and thallus $\mathrm{K}-, \mathrm{Pd}-$. No chemical substances detected by TLC.

Ecology: On siliceous rocks in mountainous area.

Distribution: So far known only from the type locality in South Korea, Eastern Asia.

Etymology: It is named after the well-known Hungarian lichenologist and our friend László Lőkös (1959-) in recognition of his contributions to recent knowledge on Korean lichen flora and who participated in collecting the type material of this taxon.

Taxonomic notes: Phyllopsora loekoesii is similar to three isidiate species of this genus, i.e.: P. corallina (Eschw.) Müll. Arg., P. intermediella (Nyl.) Zahlbr., and $P$. furfuracea (Pers.) Zahlbr., but differs from all of them in having longer ascospores $((11-) 13-16 \times 2-2.8(-3.5) \mu \mathrm{m}$ vs. $6.5-13.0 \times 2.0-3.5 \mu \mathrm{m}$ in P. corallina, $7-9 \times 2.5-3.5 \mu \mathrm{m}$ in P. intermediella, and 6-9-12 × 2-2.3-2.5 $\mu \mathrm{m}$ in P. furfuracea) 

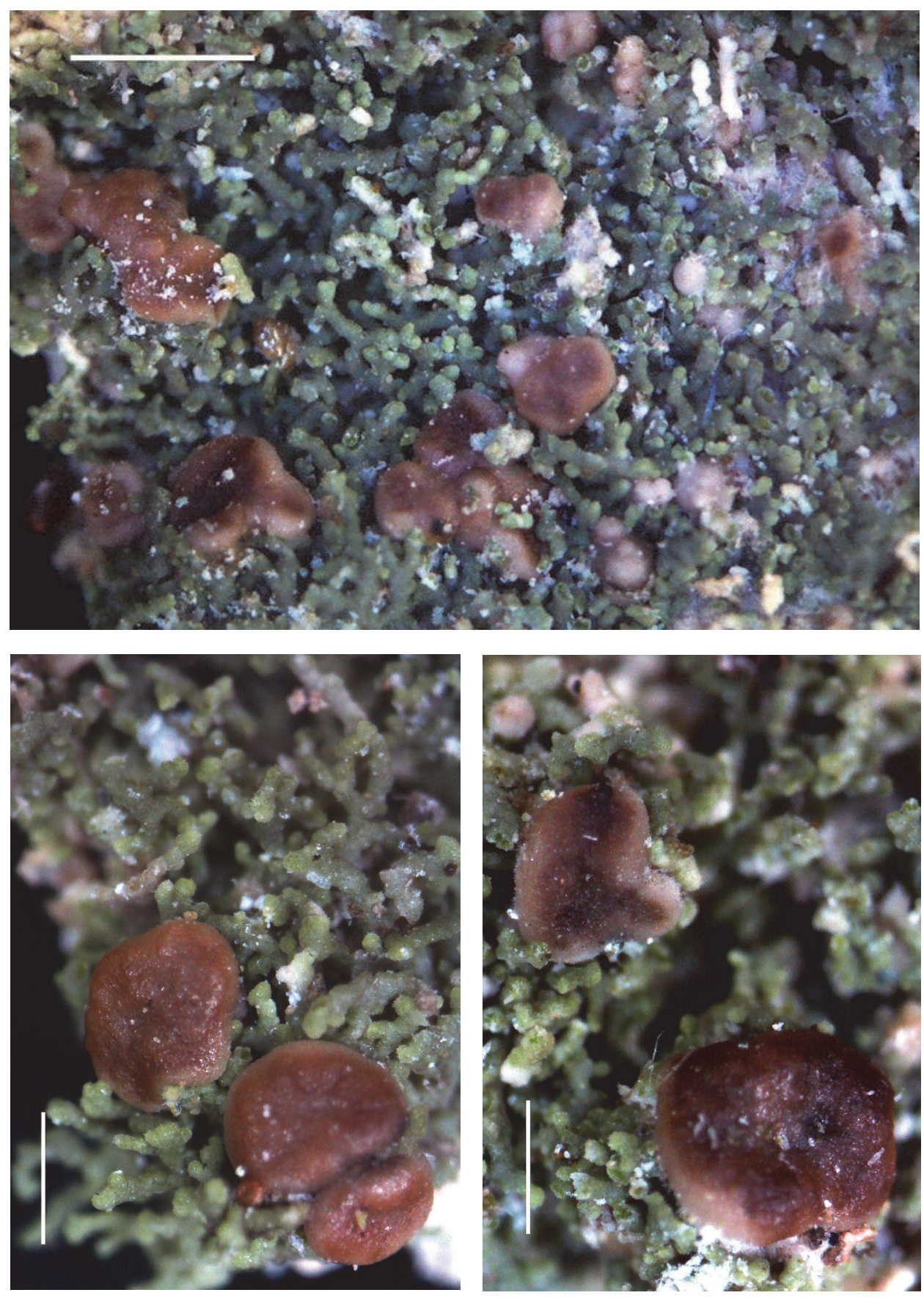

Fig. 13. Phyllopsora loekoesii, enlarged apothecia (holotype). Scale $1 \mathrm{~mm}$ (top), 0.5 (bottom) (photo: S. Kondratyuk) 
(Brako 1991). Furthermore, $P$. loekoesii differs from P. corallina in having longer ascospores; in having $\mathrm{Pd}-$ thallus (vs. $\mathrm{Pd}-$ or $\mathrm{Pd}+$ orange), in having long and abundantly branched isidia (vs. globose to cylindrical isidia), in having narrower cortex (to $10 \mu \mathrm{m}$ vs. 25-45 $\mu \mathrm{m}$ thick), and in the lack of crystals in cortex, in having dull brown apothecia (vs. orange-brown or reddish), in the lack of pale to red prothallus, in the lack of atranorin, argopsin, norargopsin, vicanicin, norvicanicin, phyllopsorin, chlorophyllopsorin, parvifoliin, zeorin, in the lack of red pigmented (K- or $\mathrm{K}+$ purplish brown pigment) apothecium margin, as well as hypothecium and hymenium. Phyllopsora loekoesii differs from $P$. intermediella also in having regularly cylindrical almost the same thickness of isidia throughout, mainly horizontally orientated and forming multi-stored type of thallus (vs. isidia variable, irregular, globose, cylindrical with a bulbous base or slightly flattened, to $1 \mathrm{~mm}$ long, erect), in having thinner cortical layer (to $10 \mu \mathrm{m}$ vs. to $20 \mu \mathrm{m}$ thick), in the lack of reddish prothallus, in the lack of red fibrils in apothecium margin, in having dull yellow brownish exciple (vs. reddish brown, $\mathrm{K}$ - exciple), in having only dull yellow brownish hypothecium (vs. yellow brown to partly red pigmented, $\mathrm{K}-$ ), in having lower hymenium (vs. to $50 \mu \mathrm{m}$ high). From Phyllopsora furfuracea P. loekoesii differs in also in having larger and flat thalline squamules (vs. rounded to irregular $c a 0.1 \mathrm{~mm}$ in diam., mostly slightly convex, closely adjoined and sometimes appearing as continuous crust), in having longer and abundantly branched isidia, in the lack of reddish prothallus, in having dull brown (vs. red-brown) apothecia, in the lack of abundant pale fibrils on apothecium margin, in having brown (not black) apothecia, in having yellow-brown exciple and hypothecium (vs. to partly red pigmented, containing an orange crystalline material dissolving and diffusing pale yellow to red or purplish in $\mathrm{K}$ ), in having lower hymenium ( $c a$ to $60 \mu \mathrm{m}$ ).

After having long ascospores Phyllopsora loekoesii is similar to P. longiuscula (Nyl.) Zahlbr., known from central and South America (Cuba, Puerto Rico, Venezuela), and P. kiiensis (Vainio) Gotth. Schneider, known from Japan (Asia), Kenya and Tanzania (Africa) (Upreti et al. 2003). However Phyllopsora loekoesii differs from $P$. longiuscula in having much narrower and longer, usually richly branched isidia (vs. isidia much wider, flattened, incised, and shorter, and not branched), in having thinner cortical layer (to $10 \mu \mathrm{m}$ vs. to $20 \mu \mathrm{m}$ thick), in the lack of reddish prothallus, in the lack of abundant red fibrils on apothecium margin, and in having narrower ascospores ((11-)13-16 $\times 2-2.8(-3.5) \mu \mathrm{m}$ vs. 12.5-19 × 3-4 $\mu \mathrm{m})$ (Brako 1991). Furthermore Phyllopsora loekoesii differs from $P$. kiiensis in having smaller and indistinct thalline squamules/areoles (0.2-0.4 mm vs. $0.5-1 \mathrm{~mm}$ in diam.), in having green or whitish green upper surface of thallus (vs. yellowish brown, reddish towards margins), in having another type of cortical layer (vs. cortex type 2 in P. kiiensis), 
in the lack of red or reddish brown prothallus, in having smaller apothecia (0.4-1 $\mathrm{mm}$ vs. $0.5-1.5 \mathrm{~mm}$ in diam.), in having yellow or dull yellow-orange exciple and hypothecium (vs. excipulum red tinged, and hypothecium colourless, as diagnostical characters), in having narrower ascospores ((11-)13$16 \times 2-2.8(-3.5) \mu \mathrm{m}$ vs. $10-17(-20) \times 2.5-4 \mu \mathrm{m})$ and in the lack of furfuracein.

\section{Polycoccum clauderouxii S. Y. Kondr., L. Lőkös et J.-S. Hur, spec. nova} (Fig. 14)

Mycobank no.: MB 817978

Similar to Polycoccum clauzadei, but differs in having larger galls on host thalli, in having 8-spored asci, and in having longer and narrower ascospores, as well as in having different host.

Type: China. Qinghai Province, between Jingtai and Zhongwei (close to Yellow River), along 201 Provincial Road, on soil. Lat.: $37.42216^{\circ}$ N; Long.: $104.58057^{\circ}$ E; Alt.: 1,686 m a.s.l. Coll.: Park, C. H. and Hur, J.-S. (CH-160017), 06.2016 (holotype: KoLRI sub Zeroviella laxa); the same locality, (CH-160003), (isotype: KoLRI sub Zeroviella laxa).

Lichenicolous fungus forming convex, basally distinctly constricted galls to $0.5-1.5 \mathrm{~mm}$ diam. in thalline lobes of Zeroviella laxa.

Ascomata perithecioid, totally immersed in the galls of the host lichen, more or less globose to pyriform, ostiolate, 120-180(-190) × 170-190(-210) $\mu \mathrm{m}$, black, sometimes epinecral layer (the same with epinecral layer of host cortical layer of thalline galls) observed above perithecia to 5-7 $\mu \mathrm{m}$ thick; excipulum wall brown to dark brown, $c a 15-20 \mu \mathrm{m}$ thick at the basis and to 30-40 $\mu \mathrm{m}$ wide at ostiole. Paraphyses present, richly branched and anastomosed, septate, to 2 $\mu \mathrm{m}$ thick; asci 8-spored, elongate, clavate, $65-70 \times 12-13 \mu \mathrm{m}$; ascospores from greenish brown to dark brown or blackish brown at overmature, with granules to $0.5 \mu \mathrm{m}$ across; (16-)18-20(-21) × 6-7 $\mu \mathrm{m}$. Pycnidia not seen.

Host: Zeroviella laxa growing on soil in mountain deserts.

Distribution: So far known only from the type locality in Ginghai Province of China, Eastern Asia.

Etymology: It is named after the well-known French lichenologist and specialist on lichenicolous fungi Claude Roux (1945-), who has described also Polycoccum clauzadei to which new taxon shows the highest similarity.

Taxonomic notes: Polycoccum clauderouxii is positioned in somewhat intermediate position between P. clauzadei Nav.-Ros. et C. Roux and P. pulvinatum (Eitner) R. Sant. (= P. galligenum Vězda). However, after ascospores and in having different hosts $P$. clauderouxii is quite different from the both taxa mentioned. 
Polycoccum clauderouxii is similar to P. clauzadei, but differs in having larger galls on host thalli (0.5-1.5 mm vs. (0.2-) 0.4-0.8 mm diam./across), in having 8-spored (vs. 4-6-spored) asci, and in having longer and narrower ascospores ((16-)18-20(-21) × 6-7 $\mu \mathrm{m}$ vs. 15-18.5(-19.5) × (6.5-)7-9(-9.5) $\mu \mathrm{m})$, as well as in having different host (Zeroviella laxa vs. Rusavskia elegans).

Furthermore Polycoccum clauderouxii differs from P. pulvinatum, in having different hosts (Zeroviella laxa vs. Physcia spp.), in having smaller galls on host thallus (0.5-1.5 mm vs. (0.5-)1-3 mm diam./across), in having smaller ascomata (120-180 $\mu \mathrm{m}$ vs. 150-300 $\mu \mathrm{m}$ diam./across), in having 8-spored (vs. (4-)8-spored) asci, and in having narrower ascospores $((16-) 18-20(-21) \times 6-7$ $\mu \mathrm{m}$ vs. 14-21 × 6-9 $\mu \mathrm{m})$ (Navarro-Rosinés and Roux 1998).

It is interesting that Rusavskia elegans, the host of a gall-forming lichenicolous fungus Polycoccum clauzadei, and Zeroviella laxa, the host of a similar (to latter) gall-forming lichenicolous fungus Polycoccum clauderouxii are members of the same Rusavskia clade of the subfamily Xanthorioideae of the Teloschistaceae. The genus Zeroviella was recently segregated from the genus Rusavskia on the basis of three gene phylogeny (Kondratyuk et al. 2015c). Finding of different lichenicolous fungi on member of these two genera, i.e. Rusavskia and Zeroviella, is additional confirmation that these lichen groups are quite different. Furthermore, Zeroviella laxa was recently erected to the species level also (Kondratyuk et al. 2015c).

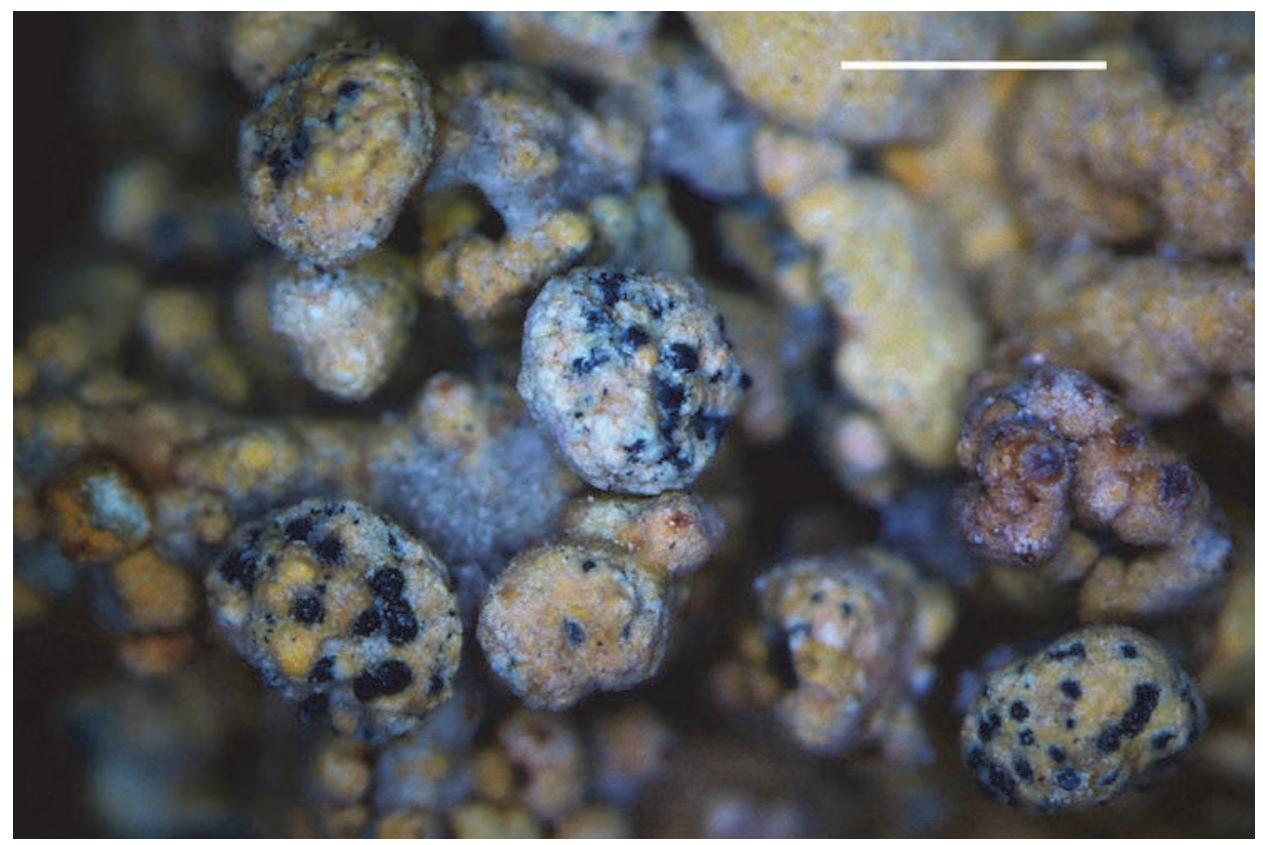

Fig. 14. Polycoccum clauderouxii (holotype), general habit. Scale $1 \mathrm{~mm}$ (photo: S. Kondratyuk) 
Psoroglaena coreana S. Y. Kondr., L. Lőkös et J.-S. Hur, spec. nova (Fig. 15)

Mycobank no.: MB 817979

Similar to Psoroglaena japonica, but differs in having more or less continuous thallus, in having hyaline and smaller perithecia, in having larger algal cells, in having hyaline and thinner exciple, in having wider periphyses, in having lower hymenium, in having 1-3-septate, and longer and wider ascospores.

Type: Republic of Korea, Gyeongsangbuk-do, Ulleung-do Island, Ulleung-gun, Seomyeon, Taeha-ri, valley of Tae-hacheon, Seodal-gil, near Bogho waterfall, on beton kerb, growing together with Bacidina egenula, and Verrucaria sp. Lat.: 37 $30^{\prime} 14.09^{\prime \prime} \mathrm{N}$; Long.: $130^{\circ}$ 50’ 07.83" E; Alt.: 370 m a.s.l. Coll.: Kondratyuk, S. Y. and Lőkös, L. (161845), 10.07.2016 (holotype: KoLRI 040045 sub Bacidina egenula).

Thallus crustose, continuous, green or greenish grey, perithecia as whitish or yellow-whitish tips, to $0.1-(0.2) \mathrm{mm}$ in diam. seen. Thallus in section to $50 \mu \mathrm{m}$ thick, continuous crust, no goniocysts observed. Algae 7-14 $\mu \mathrm{m}$ in diam.

Perithecia to (110-)120-180(-220) $\mu \mathrm{m}$ in diam. and to 150-190 $\mu \mathrm{m}$ high in section, immersed in substratal rocks only at base, subglobose to globose, ellipsoidal or pyriform, algal layer at the lower half of exciple to 25-35 $\mu \mathrm{m}$ thick, continuous (not goniocystal type). Exciple to (12-)17-25(-35) $\mu \mathrm{m}$ thick in lower portion, while to $25-50(-60) \mu \mathrm{m}$ thick at the ostiole, pseudoparenchymatous, cell lumina of $5 \mu \mathrm{m}$; hyaline throughout or at the ostiole somewhat pinkish or yellowish; periphyses (8-)15-25(-40) $\mu \mathrm{m}$ long and (1.5-)2-3 $\mu \mathrm{m}$ wide; hymenium to 70-80 $\mu \mathrm{m}$ high; asci 8-spored, (50-)60-75 $\times 11-13 \mu \mathrm{m}$; ascospores 1-3-septate, central septum is somewhat curved (not straight or even) often with oil droplets, slightly wider when bent, (16-)18-22 × (5-)5.56.5(-7.5) $\mu \mathrm{m}$. Conidiomata and conidia unknown.

Ecology: On siliceous and calcium containing rocks.

Distribution: So far known from scattered localities in South Korea, Eastern Asia.

Etymology: It is named after the country, i.e. South Korea, where type collection was made.

Taxonomic notes: Psoroglaena coreana is characterised by continuous green thallus, whitish perithecia to $0.2 \mathrm{~mm}$ diam., 1-3-septate, rather long and narrow ascospores and the saxicolous habitat.

Psoroglaena coreana is similar to $P$. japonica $\mathrm{H}$. Harada, growing on friable rocks in shade in damp, semi-aquatic habitats and around lucidophyllous forests dominated by evergreen Quercus in hilly area in the temperate zone on the Pacific side of Honshu, Central Japan, but differs in having more or less continuous thallus (not farinose thallus consisting almost exclusively of goni- 
ocysts), in having hyaline (vs. pale orange brown or medium to dark brown) perithecia, in having thalline clusters to $25-50 \mu \mathrm{m}$ (vs. goniocysts to 10-20 $\mu \mathrm{m}$ diam./across), in having larger algal cells (7-14 $\mu \mathrm{m}$ vs. 3-10 $\mu \mathrm{m}$ diam.),
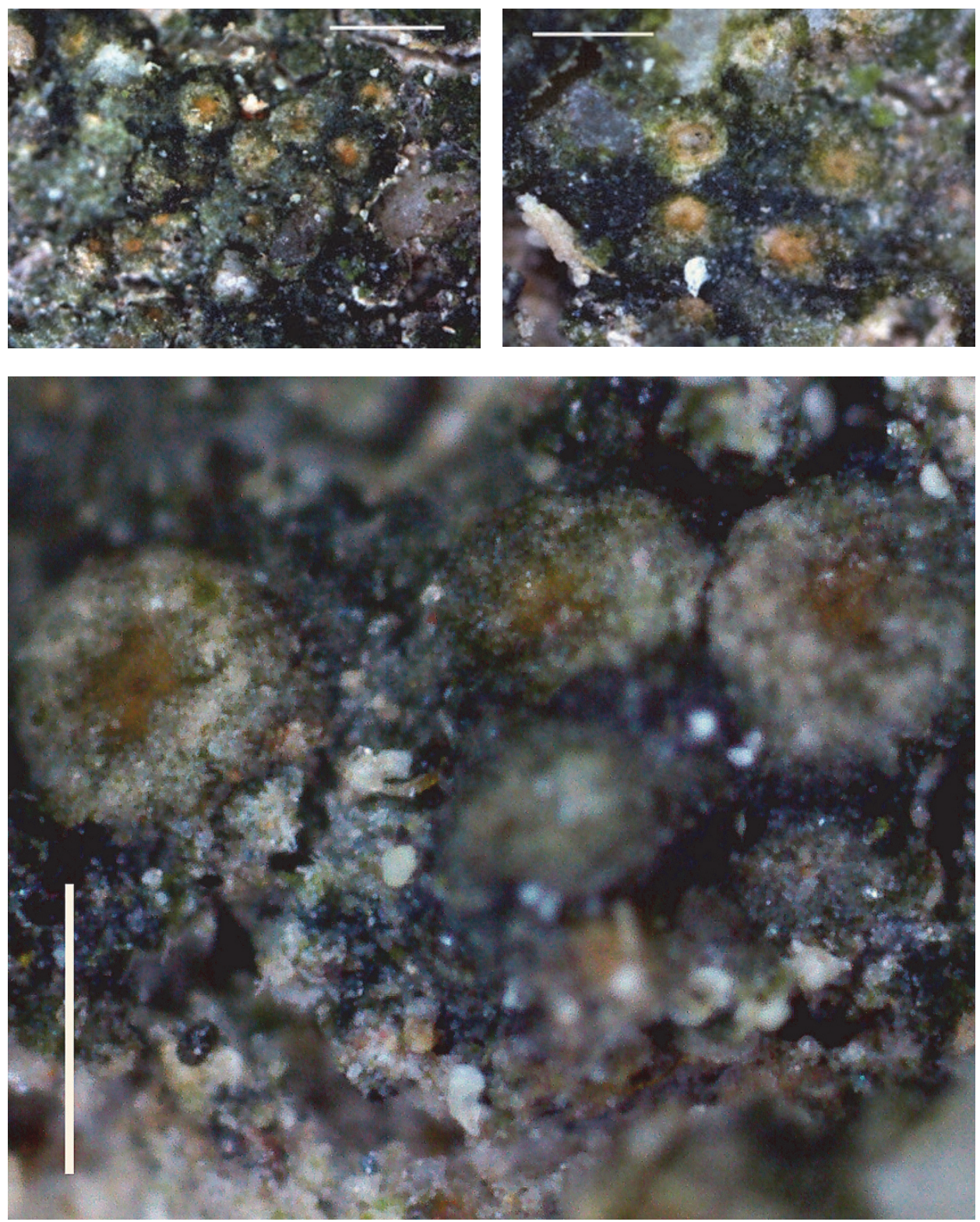

Fig. 15. Psoroglaena coreana (holotype), general habit (top), enlarged ascomata (bottom). Scales $0.5 \mathrm{~mm}$ (photo: S. Kondratyuk) 
in having smaller perithecia in section (to $120-180(-220) \mu \mathrm{m}$ vs. $250-350 \mu \mathrm{m}$ diam. and 150-190 $\mu \mathrm{m}$ vs. 260-330 $\mu \mathrm{m}$ high), in having hyaline (vs. orange brownish or brown in the outer layer) and in having thinner exciple (to $25 \mu \mathrm{m}$ vs. 35-65 $\mu \mathrm{m}$ thick at the sides, and $25-50 \mu \mathrm{m}$ vs. 50-90 $\mu \mathrm{m}$ thick in the upper part), in having wider periphyses $(2-3 \mu \mathrm{m}$ vs. $1-1.5 \mu \mathrm{m})$ in having lower hymenium (70-80 $\mu \mathrm{m}$ vs. 140-280 $\mu \mathrm{m}$ high), in having 1-3-septate (vs. 3-septate), and longer and wider ascospores ((16-)18-22 × (5-)5.5-6.5(-7.5) $\mu \mathrm{m}$ vs. 13-17 × 5-6 $\mu \mathrm{m})$ (Harada 2003).

Psoroglaena coreana is similar to P. stigonemoides (A. Orange) Henssen, but differs in having 1-3-septate (vs. 3-5-septate) ascospores, in the lack of granulose thallus (i.e. thallus "often disintegrating into soredia-like granules" (Orange 1991), and in having mainly hyaline (vs. pale orange-brown) perithecia and in different substrate (vs. grows on the bark of trees) (Orange 1989).

Psoroglaena abscondita (Coppins et Vězda) Hafellner et Türk, $P$. hepaticola (Döbbeler et Vězda) H. Harada and P. perminuta (Vězda) H. Harada also have 3-septate ascospores, but they have smaller perithecia (up to $0.2 \mathrm{~mm}$ in diam.) and are either foliicolous (the latter two species (Döbbeler and Vězda 1982, Vězda 1973)) or corticolous (P. abscondita, Orange 1991).

Thallus of $P$. coreana usually to $50 \mu \mathrm{m}$ thick continuous crust, which only in very wet conditions (sometimes in place of contact with bryophytes) may form thalline portions to $0.1-0.15 \mathrm{~mm}$ across, which seem to be dissolved into smaller granules to $20-50 \mu \mathrm{m}$ diam./across. However, these thalline granules are very irregular and they do not have special "cortical layer", so they cannot be considered as "goniocysts" sensu Vězda.

Other specimens examined: Republic of Korea. Gyeongsangbuk-do, Ulleung-do Island, Ulleung-gun, Ulleung-eup, Jeodong-ri, on rock wall along path to Bongrae waterfall. Lat.: $37^{\circ} 29^{\prime} 52.10^{\prime \prime} \mathrm{N}$; Long.: $130^{\circ} 53^{\prime} 19.72^{\prime \prime}$ E; Alt.: $285 \mathrm{~m}$ a.s.l. Coll.: Kondratyuk, S. Y. and Lőkös, L. (161538), 09.07.2016 (KoLRI 039756); the same locality, (161517), (KoLRI 039735); the same locality, (161631), (KoLRI 039849); the same locality, (161638), (KoLRI 039856). - Gyeongsangbuk-do, Ulleung-do Island, Ulleung-gun, Ulleung-eup, between Naesujeon and Soekpo waterfall, on siliceous rocks, growing together with Lecania rinodinoides, and Rinodina damaged by Arthonia rinodinicola. Lat.: $37^{\circ} 30^{\prime} 59.62^{\prime \prime}$ N; Long.: $130^{\circ} 54^{\prime} 17.54^{\prime \prime}$ E; Alt.: 285 m a.s.l. Coll.: Kondratyuk, S. Y. and Lőkös, L. (161646), 09.07.2016 (KoLRI 039864).

Psorotichia gyelnikii S. Y. Kondr., L. Lőkös et J.-S. Hur, spec. nova (Fig. 16)

Mycobank no.: MB 817980

Similar to Psorotichia murorum, but differs in having only areolate thallus, in having thinner thalline areolae, in having dark brown upper surface, in having cryptolecanorine apothecia, as well as in having shorter ascospores. 
Type: Republic of Korea. Jeju-do, Seogwipo-si, Seongsan-eup, Goseong-ri, Seopjicoji, on rocks, growing together with Caloplaca pelodella, Buellia sp., Caloplaca cf. subsoluta and

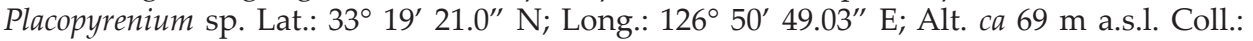
Lőkös, L. (140390-1), 19.06.2014 (holotype: KoLRI 022768 sub Psorotichia); the same locality, Coll.: Halda, J. (140444), 19.06.2014 (isotype: KoLRI 022841 sub Psorotichia).

Thallus to several $\mathrm{cm}$ across, crustose, forming almost continuous crust, which areolate in fact (seen at the highest magnification, at $\times 100$ and more), very thin and closely attached to the substrate, dark brown or pure brown when dry. Thalline areoles $0.2-0.4(-0.6) \mathrm{mm}$ diam./across, and to (60)100$150(-250) \mu \mathrm{m}$ thick in section, irregular or more or less rounded, more or less distant, rarely somewhat aggregated especially if areoles fertile; thalline areole surface not granular, more or less smooth, or rarely with more or less irregular granules to 20-30 $\mu \mathrm{m}$ across. Hypothallus not observed.

Apothecia to 130-190 $\mu \mathrm{m}$ wide in section; immersed or sunken into thalline areoles, seen as concave or urn-like cavity/disc to $0.05-0.1(-0.15) \mathrm{mm}$ in diam., concolorous with thallus, dark brown or blackish brown; often aggregated to 1-3(-5) apothecia per thalline areole; algal packets in thalline margin brownish-reddish; exciple to $5(-10) \mu \mathrm{m}$ thick, consisting of very small, $2-3 \mu \mathrm{m}$ diam./across, and rounded cells, or indistinct or not seen in places; hymenium to (50-)80-130(-180) $\mu \mathrm{m}$ high, IKI+ blue; epihymenium dull brownish or brownish green or greyish; paraphyses $2-3 \mu \mathrm{m}$ wide, branched; asci 8-spored, $45-55(-60) \times 15-16 \mu \mathrm{m}$, often with various size of ascospores in the same ascus; ascospores widely ellipsoid or more or less spherical, (9-)10-13(-15) $\times$ $(6-) 7-8(-9) \mu \mathrm{m}$, or 7-9 $\mu \mathrm{m}$ in diam., if spherical. Conidiomata very inconspicuous, immersed into thalline areoles, often in the same areole with apothecia; in wet condition conidiomata somewhat better distinct than apothecia, because becoming convex in contrast to apothecia, which becoming completely indistinct (the same thickness as thalline areoles in wet conditions); conidia bacilliform or elongated ellipsoid, 2.5-4 ×0.9-1.1 $\mu \mathrm{m}$.

Ecology: On siliceous rocks in coastal zone.

Distribution: So far known only from several localities of coastal zone of South Korea, Eastern Asia.

Etymology: It is named after the well-known Hungarian botanist, mycologist, lichenologist Vilmos Kőfaragó-Gyelnik (1906-1945) for his contribution to lichenology in general and to recent knowledge on cyanolichens especially.

Taxonomic notes: Psorotichia gyelnikii is similar to P. murorum A. Massal. in having large thalline areoles, in having many small apothecia per areole, in having I+ blue hymenium, and in having very thin true exciple, but differs in having only areolate (not granulose) thallus, in having thinner thalline areoles (to $0.1(-0.25) \mathrm{mm}$ vs. $0.3-0.5 \mathrm{~mm}$ thick), in having dark brown (not black) upper surface, in having cryptolecanorine apothecia (margin not 

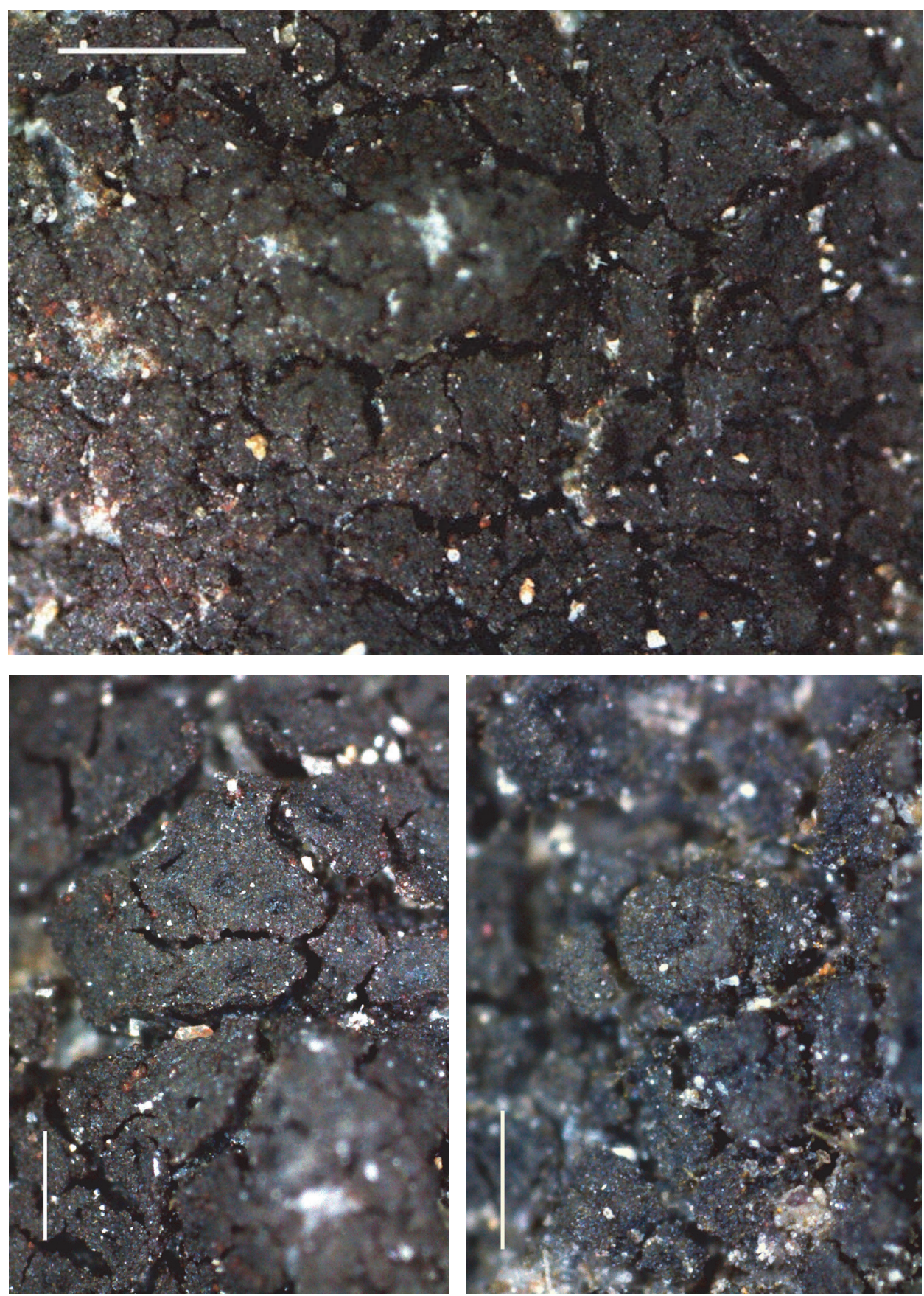

Fig. 16. Psorotichia gyelnikii (holotype), general habit (top), enlarged apothecia (bottom). Scale $1 \mathrm{~mm}$ (top), $0.5 \mathrm{~mm}$ (bottom) (photo: S. Kondratyuk) 
prominent, vs. with persisting, smooth thalline margin), as well as in having shorter ascospores $((9-) 10-13(-15) \times(6-) 7-8(-9) \mu \mathrm{m}$ vs. $(10-) 12.5-17.5(-20) \times$ 7.5-10 $\mu \mathrm{m})$.

Unfortunately conidia of Psorotichia murorum are hitherto not observed. In P. gyelnikii conidia bacilliform or elongated ellipsoid, 2.5-4 ×0.9-1.1 $\mu \mathrm{m}$.

In having I+ blue hymenium Psorotichia gyelnikii is similar to $P$. numidella (Nyl.) Forssell, described originally from North Africa (Sakhara) and known from SW Europe and North America (Sonoran) at the moment, but differs in having smaller thalline areoles $(0.2-0.4 \mathrm{~mm}$ vs. $0.3-0.8(-1) \mathrm{mm}$ across), in having areolate (not being granulose) thallus, in having dark brown (not blackish) upper surface of thallus, in having smaller apothecia (to $0.1-0.15 \mathrm{~mm}$ vs. $0.15-0.3 \mathrm{~mm}$ diam.), in the lack of rizohyphae and in the lack of bluish green epihymenium, as well as apothecia not becoming black and not contrasting with thallus when wet (vs. especially P. numidella var. flageyana J. Steiner).

The 'KoLRI 022731' specimen (coll. num. 140365) having widely ellipsoid to widely bacilliform conidia, (1.5-)2-3.2 × (0.8-)1.2-1.5(-1.7) $\mu \mathrm{m}$, probably belongs to another taxon. It is included here with some hesitation.

Other specimens examined: Republic of Korea. Jeju-do, Jeju-si, Hangyeong-myeon, Sinchang-ri, seashore road. Lat.: $33^{\circ} 20^{\prime} 31.6^{\prime \prime} \mathrm{N}$; Long.: $126^{\circ} 10^{\prime} 12.08^{\prime \prime}$ E; Alt.: $82 \mathrm{~m}$ a.s.l. Coll.: Halda, J. P. (140128), 18.06.2014 (KoLRI 022494); the same locality, Joshi, Y. and So, J. (140183), (KoLRI 022554 sub Psorotichia). - Jeju-do, Seogwipo-si, Seongsan-eup, Goseong-

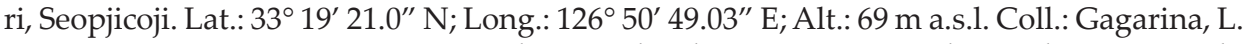
(140365), 19.06.2014 (KoLRI 022731); the same locality, growing together with Protoparmeliopsis chejuensis, (140350), (KoLRI 022718 sub Protopermeliopsis chejuensis); the same locality, growing together with Rusavskia mandshurica, Coll.: Lőkös, L. (140387_1), 19.06.2014 (KoLRI 022759 sub Rusavskia mandshurica); the same locality, Halda, J. P. (140430), 19.06.2014 (KoLRI 022827); the same locality, growing together with Catillaria and Rinodina, (140432), (KoLRI 022829 sub Rinodina); the same locality, (140436), (KoLRI 022833); the same locality, (140441), (KoLRI 022838); the same locality, growing together with Caloplaca diffluens and Orientophila fauriei, (140442), (KoLRI 022839 sub Orientophila fauriei); the same locality, Coll.: Joshi, Y. and So, J. (140489), 19.06.2014 (KoLRI 022891).

Rinodina oxneriana S. Y. Kondr., L. Lőkös et J.-S. Hur, spec. nova (Fig. 17)

Mycobank no.: MB 817981

Similar to Rinodina roboris var. roboris, but differs in having mainly squamulose to phyllidiate thallus (not granular!) and with whitish or whitish-greyish (not pinkish) at margins, in having usually narrower and whitish thalline margin, in having higher hymenium, in having larger (longer) ascospores, as well as in the lack of $K+$ yellow reactions of thallus (in the lack of atranorin). 
Type: Republic of Korea. Gyeongsangnam-do, Sancheong-gun, Sicheon-myeon, Naedae-ri, Jirisan National Park, Georim Trail, on Quercus bark, growing together with Rinodina xanthophaea. Lat.: 35 $17^{\prime}$ 23.93" N; Long.: $127^{\circ} 42^{\prime}$ 09.85" E; Alt.: 885 m a.s.l. Coll.: Kondratyuk, S. Y., Lee, B. G. and Lőkös, L. (161106), 30.06 .2016 (holotype: KoLRI 039301); the same locality, growing together with Caloplaca oxneri, (161087), (isotype: KoLRI 039282); the same locality, growing together with Pertusaria sp., (161091), (isotype: KoLRI 039286); the same locality, (161097), (isotype: KoLRI 039292); the same locality, (161098), (isotype: KoLRI 039293); the same locality, growing together with Rinodina xanthophaea, Phaeophyscia sp., (161100), (isotype: KoLRI 039295); the same locality, (161104), (isotype: KoLRI 039299); the same locality, growing together with Phaeophyscia sp., and Bacidia sp., (161113), (isotype: KoLRI 039308).

Thallus to $5-10 \mathrm{~cm}$ across, crustose, distinctly squamulose or phyllidiate, where separate squamules/phyllidia plane and distinctly dorsiventral, very often ascending, attached to the substrate by one end and seem to be isidiate, from horizontally orientated, scattered and distant in peripheral portion of thallus (and especially in case of overgrowing thalli of bryophytes) to densely aggregated of ascending squamules and forming indistinct squamulose/ phyllidiose portions, whitish grey or light grey to greyish green; squamule $0.2-0.4(-0.5) \mathrm{mm}$ diam./across, somewhat rounded or irregular, sometimes forming phyllidia ca $0.1-0.15 \mathrm{~mm}$ wide and to $0.1-0.2(-0.3) \mathrm{mm}$ long along the squamule edge. Hypothallus whitish, rarely observed.

Apothecia $0.4-1 \mathrm{~mm}$ in diam., mainly distinctly zeorine, rarely lecanorine; thalline margin usually with numerous squamules/phyllidia, true exciple well distinct, to $60-80 \mu \mathrm{m}$ thick, whitish or light brownish/greyish or transparent hyaline, well contrasting dark brown or black brown disc; disc plane, rarely convex; in section zeorine, where thalline exciple to $70 \mu \mathrm{m}$ wide, algal cells $5-12 \mu \mathrm{m}$ in diam, often aggregated in clusters to $15-25 \mu \mathrm{m}$ diam./across; and true exciple to (70-)80-120(-130) $\mu \mathrm{m}$ wide in the uppermost lateral portion with outermost layer to $20(-30) \mu \mathrm{m}$ thick brownish portion and inner hyaline, and to (30-)50-70 $\mu \mathrm{m}$ thick in lower lateral portion, scleroplectenchymatous with well developed matrix and hyphae lumina to 2-2.5 $\mu \mathrm{m}$ diam. seen, hyaline, and mainly absent or not developed in the basal portion; hymenium 120-130 $\mu \mathrm{m}$ high, epihymenium to 20-25 $\mu \mathrm{m}$ thick, paraphyses more or less adglutinated, paraphyses to $4 \mu \mathrm{m}$ wide towards the tips; subhymenium to $40-50 \mu \mathrm{m}$ thick, more yellowish or lightly yellow-brownish; asci 8-spored, $110 \times 30 \mu \mathrm{m}$; ascospores with somewhat attenuated ends, especially at one end, $(20-) 23-30(-32) \times(10-) 11-16 \mu \mathrm{m}$.

Chemistry: not studied.

Ecology: On bark of Quercus trees where often associated with Rinodina xanthophaea, Caloplaca oxneri and various species of the genera Phaeophyscia, Bacidia, Biatora, etc. 

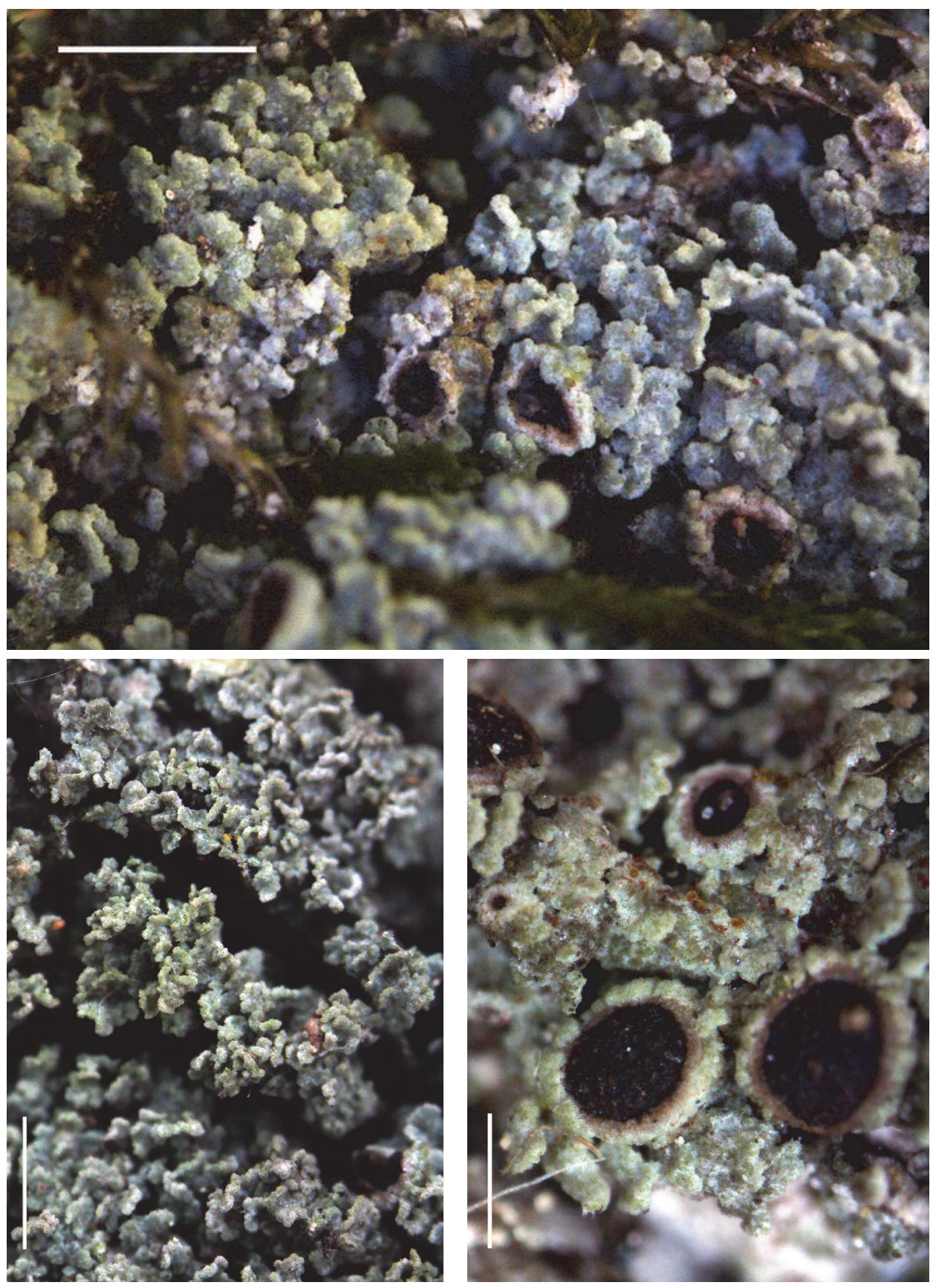

Fig. 17. Rinodina oxneriana (holotype), general habit (top, bottom left), enlarged apothecia (bottom right). Scale $1 \mathrm{~mm}$ (top, bottom left), $0.5 \mathrm{~mm}$ (bottom right) (photo: S. Kondratyuk) 
Distribution: So far known from scattered localities in South Korea, Eastern Asia, where sometimes rather abundant.

Etymology: It is named after the well-known Ukrainian lichenologist Alfred Oxner (Kiev, Ukraine) (1898-1973) in recognition of his contribution to study of Eastern Asian lichens, as well as after similarity with Caloplaca oxneri having the same type of squamulose/phyllidiate type of thallus, which can be accepted as isidiate thallus, too.

Taxonomic notes: Among all species of the genus Rinodina with Pachysporaria-type of ascospores Rinodina oxneriana is characterised by squamulose or phyllidiate thallus, distinctly zeorine apothecia with whitish or light greyish/ brownish/transparent true exciple and very large ascospores.

Rinodina oxneriana is similar to Rinodina roboris (Nyl.) Arnold var. roboris, growing on well-lit bark, especially rough barked trees, such as Quercus and Fraxinus, but also on Fagus, locally common in W Europe, Macaronesia, N America and Asia, and characterised by the usually pale grey ( $\mathrm{K}+$ yellow) thallus, the large flat apothecia with relatively thick, more or less crenulate thalline exciple and by Pachysporaria-type of ascospores, in having continuous or often irregularly cracked, flat, and often slightly squamulose and differently coloured margins and in having Pachysporaria-type of ascospores, but differs in having mainly squamulose to phyllidiate thallus (not granular!) and with whitish or whitish-greyish (not pinkish) at margins, in having usually narrower and whitish thalline margin (vs. thalline exciple $0.1-0.5 \mathrm{~mm}$ wide, concolorous with thallus), in having higher hymenium (120-130 $\mu \mathrm{m}$ vs. 95-115 $\mu \mathrm{m}$ tall), in having larger (longer) ascospores $((20-) 23-30(-32) \times$ $(10-) 11-16 \mu \mathrm{m}$ vs. $14-22 \times 8-12 \mu \mathrm{m})$, as well as in the lack of $\mathrm{K}+$ yellow reactions of thallus (in the lack of atranorin) (Giavarini et al. 2009).

Rinodina oxneriana is similar to $R$. poeltiana Giralt et Obermayer, growing on horizontal branches of Quercus agrifolia in moist habitats in Europe and North America, in having Pachysporaria-type of ascospores and in having vegetative propagules, but differs in having quickly becoming lobulated or phyllidiate thallus (vs. thin, continuous, quickly becoming rimose-areolate), in having larger thalline areoles/squamules (vs. areoles up to $0.5 \mathrm{~mm}$ wide, plane), in having phyllidia (not blastidia), and finally forming entirely phyllidiate thallus and in the lack of blastidia (vs. blastidia arising from areole margins and, then areole surface, finally forming entirely blastidiate thallus, darker than thallus, spherical, $40-70 \mu \mathrm{m}$ in diam., or elongate to $80-90(-120) \times$ 90-120(-230) $\mu \mathrm{m})$; in having larger apothecia (0.4-1 mm vs. 0.4-0.5 mm diam.), in having higher hymenium $(120-130 \mu \mathrm{m}$ vs. $70-100 \mu \mathrm{m}$ tall), and in having larger ascospores $((20-) 23-30(-32) \times(10-) 11-16 \mu \mathrm{m}$ vs. $(13-) 15.5-17.5(-20) \times$ (7-)9-10.5(-13)) $\mu \mathrm{m}$ (Sheard 2004). 
Rinodina oxneriana is similar to another blastidiate species with Pachysporaria-type of ascospores $R$. perreagens Sheard, North American endemic species growing on bark or wood of Quercus and Platanus spp. at elevations of 1,280-1,950 $\mathrm{m}$ and characterised by the presence of pannarin in the thallus (and sometimes the epihymenium) and is distinguished from the southern and western European Rinodina dalmatica Zahlbr., by its lighter coloured thallus sometimes larger blastidia, apothecia with more persistent thalline margins, and its larger ascospores. But Rinodina oxneriana differs from $R$. perreagens in having phyllidiate thallus (vs. discontinuous at first, becoming rimose and sometimes areolate, areoles up to $c a 0.6 \mathrm{~mm}$ wide); in the lack of soredia (vs. soredia 15-45 $\mu \mathrm{m}$ in diam., often covering large areas of thallus, sometimes with blastidia up to $0.1 \mathrm{~mm}$ long; in having plane apothecia (vs. becoming convex), in having whitish and wider (?) thalline margin (vs. 0.05-0.1 mm wide, sometimes incomplete), in the lack of zeorine type of apothecia (excipular ring usually prominent and raised), in having higher hymenium (120-130 $\mu \mathrm{m}$ vs. 80-120 $\mu \mathrm{m}$ high), in the lack of reddish brown epihymenium with superficial pannarin crystals (Pd+ forming red crystals), in having 8-spored asci (vs. sometimes only 6 fully developed ascospores), in having wider range of ascospore variation $((20-) 23-30(-32) \times(10-) 11-16 \mu \mathrm{m}$ vs. $(21.5-) 26-27.5(-32)$ $\times(10.5-) 13-14(-16.5) \mu \mathrm{m})$, and in the lack of $\mathrm{K}+$ faint yellow and $\mathrm{Pd}+$ immediately orange-red reaction and in the lack of pannarin, zeorin and other substances (Sheard 2004).

Rinorina oxneriana is similar to $R$. isidioides (Borrer) H. Olivier, rare species of oceanic Europe, N America and E Africa, growing on bark or more rarely amongst mosses overgrowing bark of mature Quercus, in ancient woodlands, but differs in having distinctly squamulose/phyllidiate (not isidiate) thallus, where separate lobules/phyllidia plane and distinctly dorsiventral, very often ascending, attached to the substrate by one end and seem to be isidiate (vs. isidia more or less cylindrical, minute, coralloid, branched and thin, only sometimes appressed or like folded squamules), in having whitish thalline margin, which contrasting both dark brown or black apothecium disc and grey or whitish grey to greenish grey thallus (vs. thalline exciple 0.1-0.15 mm thick, concolorous with thallus), in having brownish epithecium (not red-brown); in having somewhat narrower ascospores ((20-)23-30(-32) $\times(10-) 11-16 \mu \mathrm{m}$ vs. $21-31.5 \times 11.5-17 \mu \mathrm{m})$, and in the lack of $\mathrm{K}+$ yellow reaction of thallus and in the lack of atranorin, as well as in different ecology (i.e. very often growing amongst mosses overgrowing bark of deciduous trees) (Giavarini et al. 2009).

After having squamulose/phyllidiate thallus Rinodina oxneriana is somewhat similar with Caloplaca oxneri with which it sometimes growing side by side. However, C. oxneri has usually distinctly yellowish or yellowish-greyish 
thallus (only in shaded conditions it can be greyish green), as well as Teloschistes-type of ascus and bipolar ascospores. However, identification of steril thalli from shaded conditions can be connected with some problems. However, thalline squamules of Rinodina oxneriana are much aggregated and usually ascending in the centre of thallus, while thalline squamules/areoles of Caloplaca oxneri are usually more scattered and distant and horizontally orientated (in case if apothecia absent).

Other specimens examined: Republic of Korea. Gyeongsangnam-do, Sancheonggun, Sicheon-myeon, Naedae-ri, Jirisan National Park, Georim Trail, on Quercus bark. Lat.: 35 17' 23.93" N; Long.: 127 42' 09.85" E; Alt.: 885 m a.s.l. Coll.: Kondratyuk, S. Y., Lee, B. G. and Lőkös, L. (161115, 161116, 161120, 161129, 161131, 161135), 30.06.2016 (KoLRI 039310, KoLRI 039311, KoLRI 039315, KoLRI 039324 (dupl. BP), KoLRI 039326, KoLRI 039330). Gyeongsangnam-do, Sancheong-gun, Sicheon-myeon, Naedae-ri, Jirisan National Park, Georim Trail, on Quercus bark, growing together with Rinodina xanthophaea and Lecanora sp. Lat.: $35^{\circ} 17^{\prime} 38.70^{\prime \prime}$ N; Long.: $127^{\circ} 41^{\prime} 55.55^{\prime \prime}$ E; Alt.: 990 m a.s.l. Coll.: Kondratyuk, S. Y., Lee, B. G. and Lőkös, L. (161189), 30.06.2016 (KoLRI 039384); the same locality, growing together with Rinodina xanthophaea, Bacidia, Biatora and Lecanora spp. (161190), (KoLRI 039385).

Scoliciosporum jasonhurii S. Y. Kondr., S.-O. Oh et L. Lőkös, spec. nova (Fig. 18)

Mycobank no.: MB 817982

Similar to Scoliciosporum umbrinum in having very thin needle-shaped, spirally twisted ascospores, but differs in having light greenish or greenish-greyish thallus, in having smaller and light brown to dark brown, in having 1-septate and shorter ascospores.

Type: Republic of Korea. Jeollanam-do Prov., Goheung-gun Co., Bongnae-myeon, Queinaro-do (Wenaro) Island, Mt Bongra, on siliceous rocks, growing together with Melanophloea coreana, Gyalidea austrocoreana, Stereocaulon, Acarospora, and Ionaspis, as well as Porpidia albocaerulescens. Lat.: 34 27' 2.76" N; Long.: $127^{\circ} 30^{\prime}$ 08.16" E; Alt.: $231 \mathrm{~m}$ a.s.1. Coll.: Wang, X. Y. and Ryu, J. A. (110960), 24.10.2011 (holotype: KoLRI 013936 sub Porpidia albocaerulescens).

Thallus to 1-3 mm across rarely larger, crustose, light greenish, pale or greenish grey, very thin and often indistinct as very small portions between other crustose lichen thalli, or sometimes on thalli of Porpidia albocaerulescens in parts. Hypothallus not seen.

Apothecia very small (0.1-)0.2-0.3(-0.4) $\mathrm{mm}$ in diam.; scattered and distant or sometimes aggregated in groups (up to 3-5 apothecia) to $0.5 \mathrm{~mm}$ across, semiconvex to convex and emarginated, dull brown to dark brown. 

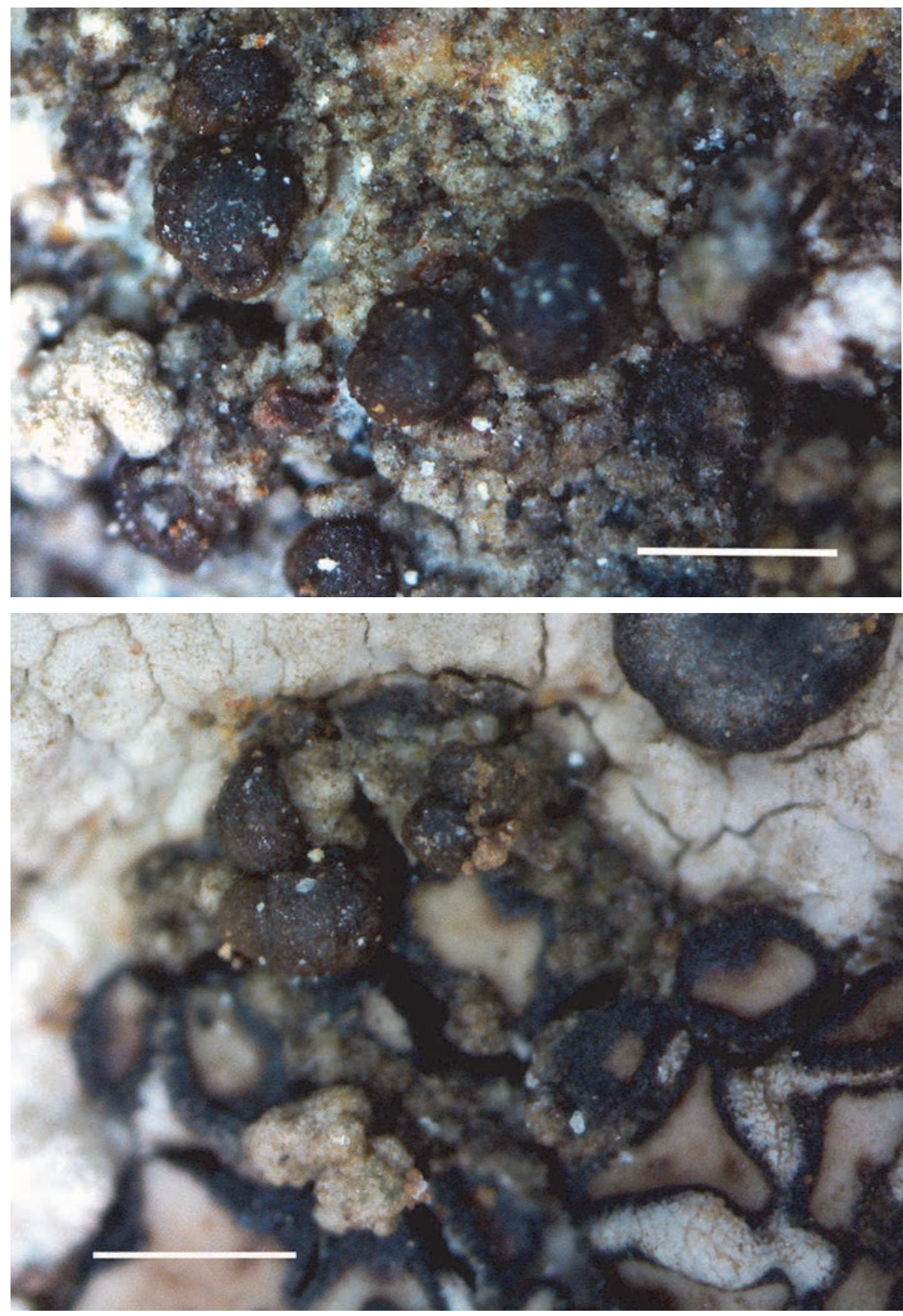

Fig. 18. Scoliciosporum jasonhurii (holotype), general habit (top), enlarged apothecia (bottom). Scale $0.5 \mathrm{~mm}$ (photo: S. Kondratyuk) 
In section to $0.45 \mathrm{~mm}$ wide and $0.3 \mathrm{~mm}$ thick, convex, biatorine, true exciple well developed while bent downwards, to 30-40(-120) $\mu \mathrm{m}$ wide in the uppermost lateral portion, to $40-50(-80) \mu \mathrm{m}$ thick in lower lateral portion, slightly brownish in section in outer layer and hyaline in inner portion, and to 40$50(-80) \mu \mathrm{m}$ thick in basal portion (in its lateral portion) and to $30 \mu \mathrm{m}$ thick in the centre of basal portion, scleroplectenchymatous, with distinct matrix and hyphae lumina 1-1.5 $\mu \mathrm{m}$ diam.; hymenium to $40-50 \mu \mathrm{m}$ high; epihymenium darkish dull olive or bluish dark brown, paraphysis tips to $5 \mu \mathrm{m}$ wide in water, and to $2 \mu \mathrm{m}$ wide in $\mathrm{K}$, and with gelatine sheath to $5 \mu \mathrm{m}$ thick (seen in $\mathrm{K}$ ); subhymenium to 60-70 $\mu \mathrm{m}$ thick, asci of Bacidia or Catillaria-type, 8-spored; ascospores needle-shaped, often spirally twisted in ascus, $12-15 \times 2 \mu \mathrm{m}$.

Chemistry: Apothecium and thallus $\mathrm{K}-, \mathrm{Pd}-$.

Ecology: On siliceous rocks often as small islands among other crustose lichens, sometimes it is problematic to make conclusion if it is not lichenicolous fungus.

Distribution: So far known only from the type locality in South Korea, Eastern Asia.

Etymology: It is named after the well-known Korean lichenologist, and our friend Dr Jae-Seoun Hur (KoLRI, Sunchon, Republic of Korea) for recognition of his contribution to recent knowledge on Korean lichen flora.

Taxonomic notes: From all known species of the genus Scoliciosporum differs in having very narrow ascospores. Scoliciosporum jasonhurii is similar to S. umbrinum in having very thin (to $2 \mu \mathrm{m}$ vs. $2-3 \mu \mathrm{m}$ wide) needle-shaped, spirally twisted ascospores, but differs in having light greenish or greenishgreyish thallus (vs. dark green-brown, occasionally rusty), in having smaller (0.2-0.3 $\mathrm{mm}$ vs. $0.3-0.8 \mathrm{~mm}$ in diam.) and light brown to dark brown (not redbrown to dark brown-black), in having 1-septate (vs. from 3- to 7-septate) and shorter (12-15 $\mu \mathrm{m}$ vs. (15-)20-30(-40) $\mu \mathrm{m}$ long) ascospores.

Staurothele oxneri S. Y. Kondr., L. Lőkös et J.-S. Hur, spec. nova (Fig. 19)

Mycobank no.: MB 817983

Similar to Staurothele levinae, but differs in having larger thallus, in having much thinner and usually closely aggregated, and not attenuated towards the tips areoles, in having grey thallus, and in having much smaller hymenial algae.

Type: Republic of Korea. Jeollanam-do, Yeosu-si, Nam-myeon, Simjang-ri, Geumodo, roadside from Yeoan Elementary school, on rocks, in coastal zone. Lat.: $34^{\circ} 28^{\prime} 58.9^{\prime \prime}$ N; Long.: $127^{\circ} 48^{\prime} 15.4^{\prime \prime}$ E; Alt.: ca 18 m a.s.l. Coll.: Kondratyuk, S. Y. (160351), 10.06.2016 (holotype: KoLRI 038496); the same locality, (160340), (isotype: KoLRI 038485). 
Thallus areolate, forming large spots to $15 \mathrm{~cm}$ across or more, with very distinct flattened marginal areoles, light grey or whitish grey especially in the peripheral portions and dark grey or somewhat brownish grey in the centre; areoles in peripheral zone to $1-2(-2.5) \mathrm{mm}$ long and to $0.2-0.4(-0.5) \mathrm{mm}$ wide in narrowest portions, becoming distinctly widened towards the tips, to (0.3-)0.7-0.8 $\mathrm{mm}$ wide, and to (0.2-)0.3-0.5 $\mathrm{mm}$ wide in the centre.

Thallus in section to $130-170(-220) \mu \mathrm{m}$ thick, leptodermatous paraplectenchymatous throughout, cells arranged more or less in vertical rows. Upper cortex up to 25-30(-35) $\mu \mathrm{m}$ thick, weakly differentiated from medulla, leptodermatous paraplectenchymatous, mainly hyaline only sometimes slightly brownish in the uppermost portion in places, cell lumina of 5-7(-10) $\mu \mathrm{m}$; usually without epinecral layer, seen only a few times to 5-10 $\mu \mathrm{m}$ thick. Medulla to $90-100 \mu \mathrm{m}$ thick, algal cells more or less evenly distributed in medulla (to $60 \mu \mathrm{m}$ thick), more or less in vertical rows. The basal layer largely variable in thickness, (25-)40-100 $\mu \mathrm{m}$ thick, the same leptodermatous paraplectenchymatous, dark brown or almost black, sometimes upper portion to 20-25 $\mu \mathrm{m}$ thick black or blackish grey while lower portion to $50-70 \mu \mathrm{m}$ thick much lighter, i.e. greyish or light brownish; tightly attached to the substrate, cell lumina of (3-)5-6(-9) $\mu \mathrm{m}$.

Perithecia pyriform to almost spherical, to $0.2-0.35(-0.4) \mathrm{mm}$ in diam., (and 250-350 $\mu \mathrm{m}$ high in section), 1/3 or 1/2 immersed into thalline areoles, only upper portion with ostiole as black uplifted portion to $0.2 \mathrm{~mm}$ diam. above level of thallus well distinct; with thalline layer almost till ostiole, involucrellum mainly merging with the basal layer of thallus; exciple dark brown to black brown in outer layer and hyaline in inner portions, to $30-40 \mu \mathrm{m}$ thick in lower lateral and basal portions, and thicker at the uppermost portion (to 90-100 $\mu \mathrm{m}$ thick, where dark portion to 30-70 $\mu \mathrm{m}$ thick and hyaline to $40(-50) \mu \mathrm{m}$ thick, cell lumina of 4-9 $\mu \mathrm{m}$ ); periphyses at ostiole to 30-40(-50) $\mu \mathrm{m}$ long and to 2-3 $\mu \mathrm{m}$ wide; hymenial algae spherical, (2-)2.5-4(-5) $\mu \mathrm{m}$ in diam., or elongated ellipsoid, oblong to bacilliform, (3-)3.5-7(-9) $\times(2-) 3-5 \mu \mathrm{m}$, sometimes pairs, tetrads and packets with 8 and 16 algal cells observed. Asci (1-?)2-spored, clavate. Ascospores hyaline at first, then becoming yellowish to yellow-orange, widely ellipsoid, with rounded ends, often with slight constriction at the equatorial portion and seem to be divided into two equal portions, (35-)40-67(-85) $\times(13-) 15-24(-27) \mu \mathrm{m}$, sometimes with thick wall of $3 \mu \mathrm{m}$. Conidiomata to 60 $\mu \mathrm{m}$ diam. and to $80 \mu \mathrm{m}$ high in section, immersed into thallus, hyaline, closely situated to perithecia; and conidia narrowly bacilliform, 4.5-5 × $1 \mu \mathrm{m}$.

Ecology: On rocks in place with periodically running water.

Distribution: So far it is known from the type locality, South Korea, Eastern Asia.

Etymology: It is named after the well-known Ukrainian lichenologist Alfred Oxner (1898-1973) (Kiev, Ukraine), in recognition of his contribution to 
knowledge on Asian lichens and especially for his contribution to the study of the genus Staurothele in Eurasia.

Taxonomic notes: Species is characterised in having thallus with radiate flattened areolae at margins, in having 2-spored asci and rather large ascospores.

After having radiate areolae at margin it can be compared with Staurothele levinae Oxner, Asian taxon known from Central and Middle Asia regions from siliceous rocks, and S. effigurata J. W. Thomson (1990), known from acidic rocks from desert to lower montane regions of North American continent, as well as with one more American taxon S. drummondii (Tuck.) Tuck.

However, Staurothele oxneri differs from S. levinae in having larger thallus, in having much thinner and usually closely aggregated (not being distant each other), and not attenuated towards the tips areoles, in having grey (not dark brown or black-brown) thallus, and in having much smaller hymenial algae (vs. 2.7-5.2 $\mu \mathrm{m}$ diam./across), while ascospores of these two species are considerably overlapping ( $40-67 \times 15-24 \mu \mathrm{m}$ vs. $28-52 \times 15.6-26 \mu \mathrm{m})$.
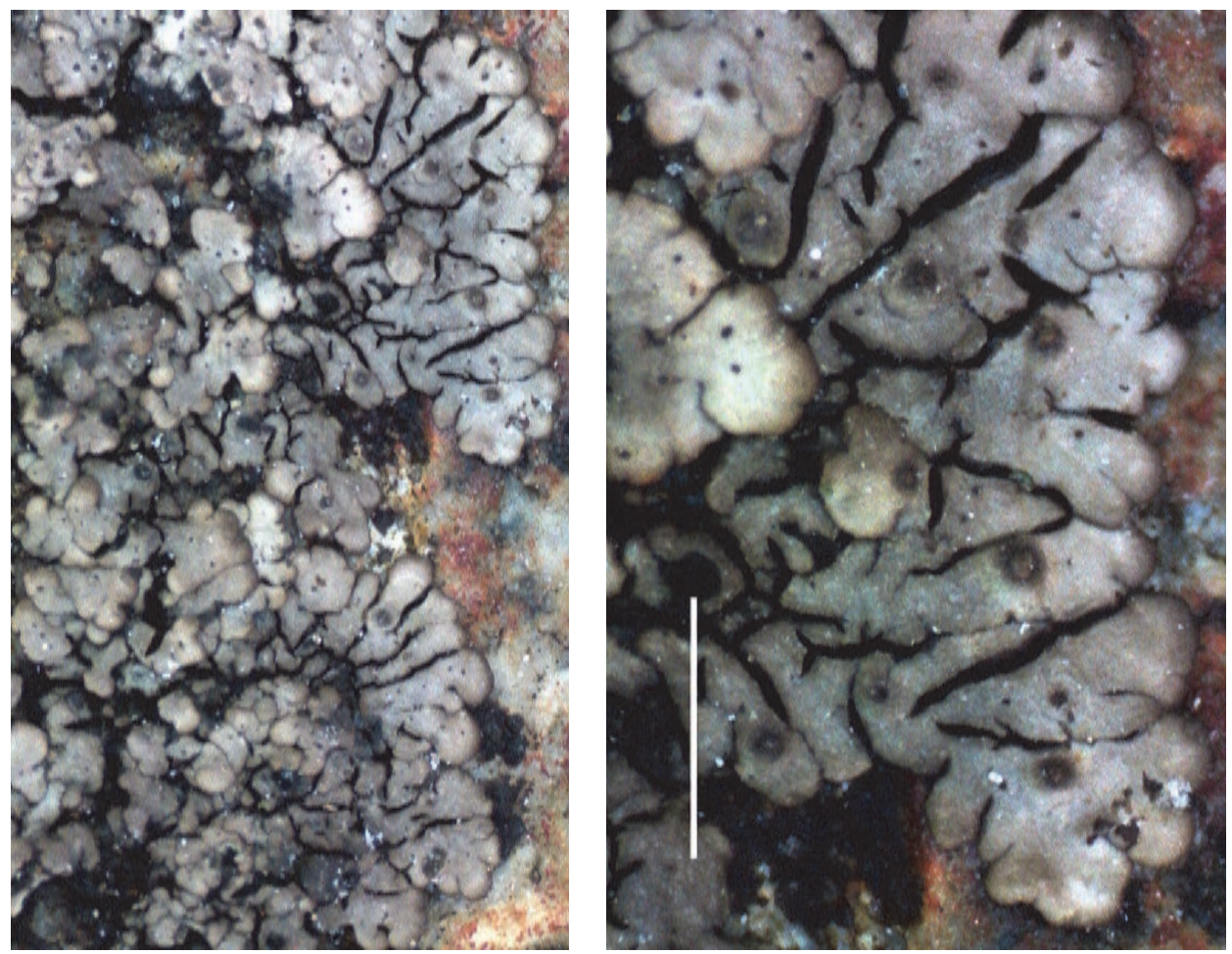

Fig. 19. Staurothele oxneri (holotype), general habit (left), enlarged radiate areoles (right). Scale $2 \mathrm{~mm}$ (left), $1 \mathrm{~mm}$ (right) (photo: S. Kondratyuk) 
Staurothele oxneri differs from S. effigurata in having narrower thalline areoles (vs. $0.3-1 \mathrm{~mm}$ broad), in having smaller radiating flattened marginal areoles (vs. to $2 \mathrm{~mm}$ long and $1 \mathrm{~mm}$ broad), in having larger perithecia (vs. up to $0.3 \mathrm{~mm}$ in diam.), in having well-visible perithecia arising thalline level (vs. perithecia within the central areoles, only the mouth visible as an inconspicuous small projections of the areole), in having larger hymenial algae (vs. predominantly 3-4 $\mu \mathrm{m}$ in diam.), in having mainly eumuriform ascospores (vs. mainly submuriform with to 7-septate transversely and 3-septate longitudinally), and

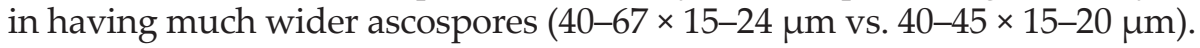

Additionally Staurothele drummondii differs from $S$. oxneri in having narrow, highly convex marginal areoles, as well as in having shining or dull brown to blackish brown upper surface, in having blackish cobwebby prothallus, in having larger perithecia (0.4-0.6 $\mathrm{mm}$ in diam.), and in having somewhat submuriform ascospores with up to 9-septate transversely and 3-septate longitudinally, and in having smaller and somewhat narrower ascospores

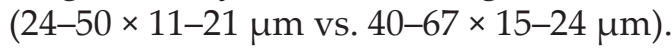

Staurothele oxneri is similar to S. elenkinii Oxner and S. lazarenkoi Oxner in having 2-spored asci and in general habitat (i.e. growing on siliceous rocks). However, Staurothele oxneri differs from S. elenkinii, known from Europe, Caucasus and North America, in having much thicker thallus, in having much better distinct perithecia and in having much larger ascospores (40-67 × 15-24 $\mu \mathrm{m}$ vs. 24-44 × 11-16.1 $\mu \mathrm{m})$. Furthermore, Staurothele oxneri differs from $S$. lazarenkoi, known hitherto from Middle Asia (Kyrgyzstan), in having much thicker and well-developed areolate, grey or light greyish brown thallus (vs. very thin and slightly areolate, brownish or olive-brown thallus), in having much larger thalline areoles (vs. $0.2-0.5 \mathrm{~mm}$ across), in having larger perithecia (vs. 0.2-0.3 mm in diam.), in having blackish brown exciple (vs. brown), as well as in having hyaline and much wider ascospores (40-67 × 15-24 $\mu \mathrm{m}$ vs. 38-46 × 11.4-19 $\mu \mathrm{m}$, and becoming dark brownish at overmature).

Three more species known hitherto for South Korea, i.e.: Willeya japonica (B. de Lesd.) Gueidan, W. iwatsukii (H. Harada) Gueidan, and Staurothele rugulosa (A. Massal.) Arnold, belong to species group, which have 8-spored asci and mainly much smaller, especially narrower, ascospores, as well as in having continuous, distinctly crustose (film-like) thallus in peripheral portions and only in the centre cracked or areolate.

Staurothele oxneri is similar to S. fissa (Taylor) Zwackh after having the perithecia covered at least partly by layer of thallus, and they form distinct mounds above the level of the rest of the thallus, but differs in having grey thallus (vs. pale brown to brown), in the lack of whitish prothallus, in having larger hymenial algae not being only in pairs and tetrads but also in larger packets (= aggregations), in having larger and especially wider ascospores $(40-67 \times 15-24 \mu \mathrm{m}$ vs. $(31-) 37-48(-55) \times(15-) 16-20(-25.5) \mu \mathrm{m})$. 
Stigmidium coarctatae S. Y. Kondr., L. Lőkös et J.-S. Hur, spec. nova (Fig. 20)

Mycobank no.: MB 817984

Similar to Stigmidium tabacinae, but differs in having much better developed, well distinct dark vegetative hyphae as well as very characteristic setae-like formations, in having superficial ascomata, in having thinner ascomata wall; in having wider and longer periphyses, in having wider ascospores.

Type: Republic of Korea. Gyeongsangbuk-do, Ulleung-do Island, Ulleung-gun, Seomyeon, Taeha-ri, valley of Tae-hacheon, Seodal-gil. Lat.: $37^{\circ} 30^{\prime} 12.77^{\prime \prime} \mathrm{N}$; Long.: $130^{\circ} 49^{\prime}$ 49.03" E; Alt.: $265 \mathrm{~m}$ a.s.l. on siliceous rocks, on thalli of Trapelia coarctata, growing together with Trapelia placodioides. Coll.: Kondratyuk, S. Y. and Lőkös, L. (161847_4), 10.07.2016 (holotype: KoLRI 040077); the same locality, on thalli of Trapelia coarctata, growing together with Trapelia placodioides, and Thelocarpon ulleungdoense, (161849), (isotype: KoLRI 040081); the same locality, on thalli of Trapelia coarctata, growing together with Trapelia placodioides, (161847_2, 161862), (isotypes: KoLRI 040075, KoLRI 040099); the same locality, on thalli of Trapelia coarctata, growing together with Trapelia placodioides, (161868), (isotype: KoLRI 040105).

Vegetative hyphae rather common and well distinct, usually of two different types: simple vegetative hyphae, dark grey to dark brown or greyish brown, to $1.5-2 \mu \mathrm{m}$ diam. and usually very long 20-50 $\mu \mathrm{m}$ long, scarsely septate, without constrictions at the septa, sometimes bulbous at the basis to 3 $\mu \mathrm{m}$ diam.; and setae-like branched formations, much darker and thicker in comparison with simple hyphae, to (5-)12-25(-30) $\mu \mathrm{m}$ long and (3-)3.5-6 $\mu \mathrm{m}$ diam. and dark brown at the bases, gradually becoming lighter and thinner towards the tips, with 2-3 or more characteristic divaricate branching.

Ascomata perithecioid, dark brownish black, spherical, (35-)50-80(-90) $\mu \mathrm{m}$ in diam. and to $60-70 \mu \mathrm{m}$ high in section, black, usually abundant and aggregated in semiconvex aggregations above host thalline areoles, with distinct superficial vegetative hyphae and setae-like formations; ascomatal wall dark brown or blackish brown, to 7-8(-12) $\mu \mathrm{m}$ thick, pseudoparenchymatous, consisting of 2(-3) layers of black cells, cells to $5-7 \times 3 \mu \mathrm{m}$, innermost one being subhyaline; periphyses well developed, $1.5-2(-2.2) \mu \mathrm{m}$ wide and to $15(-25) \mu \mathrm{m}$ long. Short pseudoparaphyses resemble those of type 'a' sensu Roux and Triebel (1994). Asci subcylindrical, narrowly elliptical, (4-)8-spored, (35-)40-45 $\times 11-12 \mu \mathrm{m}$. Ascospores hyaline, narrowly ellipsoid almost bacilliform and with equal cells, with rather acute upper and rounded lower one, not constricted at septum, usually each cells with 2 oil droplets (pseudotetrablastic), non-halonate, smooth-walled, irregularly 2-seriate in a ascus, 11-14(-17) $\times$ (3.2-)4-5(-5.5) $\mu \mathrm{m}$. 
Host: Thalline areoles of Trapelia coarctata, which sometimes completely covered by lichenicolous fungus in type locality, while thalline areoles of growing here T. placodioides side by side with $T$. coarctata were untouched by this lichenicolous fungus.

Distribution: So far known only from the type locality in South Korea, Eastern Asia.

Etymology: It is named after lichen host Trapelia coarctata.
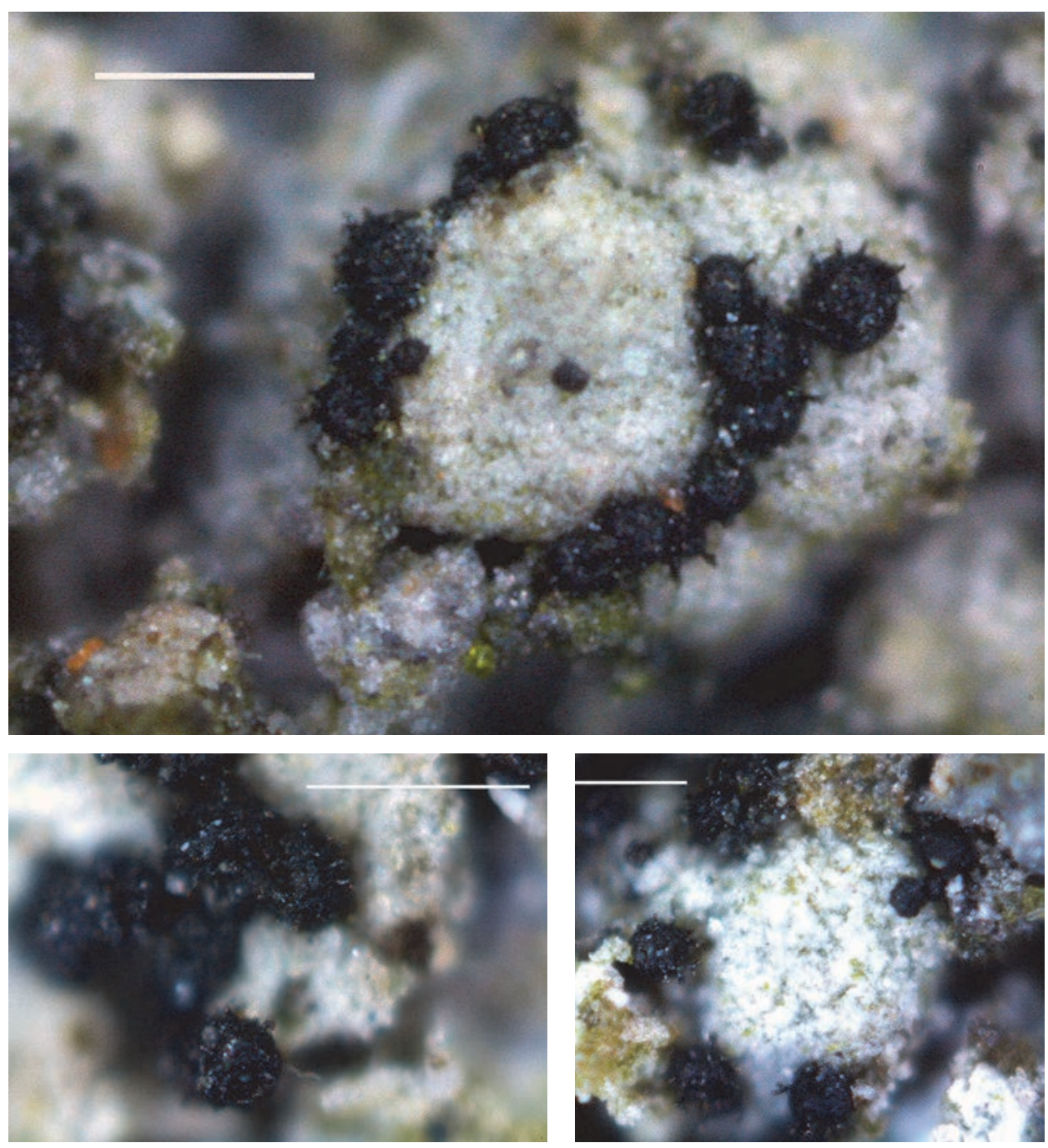

Fig. 20. Stigmidium coarctatae (holotype), enlarged ascomata with setae-like vegetative hyphae. Scale $0.5 \mathrm{~mm}$ (top), $200 \mu \mathrm{m}$ (bottom) (photo: S. Kondratyuk) 
Taxonomic notes: Stigmidium coarctatae is similar to S. tabacinae (Arnold) Triebel, known from Europe and North America, growing on thallus of Toninia physaroides and T. tristis, but differs in having much better developed, well distinct dark (vs. colourless, some pale brown) vegetative hyphae, as well as very characteristic setae-like formations, in having superficial (vs. semi-immersed to immersed) ascomata, in having thinner ascomata wall (7-8 $\mu \mathrm{m}$ vs. mostly 10-12 $\mu \mathrm{m}$ thick); in having wider and longer periphyses (to $2(-2.2) \mu \mathrm{m}$ wide and 15(-25) $\mu \mathrm{m}$ long vs. $1.5 \mu \mathrm{m}$ in diam. and ca $6 \mu \mathrm{m}$ long), in having wider ascospores $(11-14(-17) \times(3.2-) 4-5(-5.5) \mu \mathrm{m}$ vs. $10-14 \times 3-4 \mu \mathrm{m})$.

Stigmidium coarctatae closely resembles some other host thallus-inhabiting species of the genus, viz. S. fuscatae (Arnold) R. Sant., S. psorae (Anzi) Hafellner, S. epixanthum Hafellner, S. gyrophorarum (Arnold) D. Hawksw. etc. (Roux and Triebel 1994, Roux et al. 1995, Triebel and Cáceres 2004). However, all these species grow on different host taxa (most Stigmidium Trevis. species are supposed to be confined to a particular host genus) and have significantly larger ascomata, shorter asci and ascospores (mainly longer of $15 \mu \mathrm{m}$, maximum up to $23.5 \mu \mathrm{m}$ long). Furthermore, Stigmidium fuscatae, growing on Acarospora sect. Phaeothallina, differs in having smaller ascospores. Stigmidium psorae is characterized by 1-3-septate and much longer ascospores. Stigmidium epixanthum growing on Acarospora sect. Acarospora has much wider ascospores, and S. gyrophorarum differs in having much longer and wider ascospores, too.

Additional specimen examined: Republic of Korea. Gyeongsangbuk-do, Ulleung-do Island, Ulleung-gun, Seomyeon, Taeha-ri, valley of Tae-hacheon, Seodal-gil, on siliceous rocks, on thalli of Trapelia coarctata growing together with Thelocarpon ulleungdoense. Lat.: 37 30' 12.77" N; Long.: $130^{\circ} 49^{\prime}$ 49.03" E; Alt.: 265 m a.s.l. Coll.: Kondratyuk, S. Y. and Lőkös, L., 10.07.2016 (161847_1), (KoLRI 040074 sub Trapelia coarctata).

\section{Thelocarpon ulleungdoense S. Y. Kondr., L. Lőkös, J.-J. Woo et J.-S. Hur, spec. nova}

(Fig. 21)

Mycobank no.: MB 817985

Similar to Thelocarpon albidum, but differs in having single, scattered ascomata, in having much thinner true exciple, in having much higher number of ascospores in ascus, and in having much smaller ascospores and in its distribution.

Type: Republic of Korea. Gyeongsangbuk-do, Ulleung-do Island, Ulleung-gun, Seomyeon, Taeha-ri, valley of Tae-hacheon, Seodal-gil, on siliceous rocks, growing together with Trapelia coarctata damaged by lichenicolous fungus, Trapelia placodioides. Lat.: $37^{\circ} 30^{\prime}$ 12.77" N; Long.: $130^{\circ} 49^{\prime}$ 49.03" E; Alt.: 265 m a.s.l. Coll.: Kondratyuk, S. Y. and Lőkös, L., 10.07.2016 (holotype from J.-J. Woo [specimen 68 - photo); the same locality, (161849), (isotype: KoLRI 040081). 
Thallus greenish, somewhat indistinct; in section thalline portion outside perithecium to $200 \mu \mathrm{m}$ thick, ecorticate, completely filled out by algal cells.

Perithecia $0.19-0.25 \mathrm{~mm}$ in diam., semi-immersed, only to 0.5 of their height with corticated thalline sheath, lower portion immersed in algal zone; cortical layer to $10-15(-20) \mu \mathrm{m}$ thick, present in the thalline verrucae to $2 / 3$ of perithecium height, outer layer dull brownish or brownish yellow owing to richly present yellow-brown pruina; algal sheath $20-50(-70) \mu \mathrm{m}$ wide; algal cells 8-12 $\mu \mathrm{m}$ in diam./across.; nucleus to (160-)170-220(-250) $\mu \mathrm{m}$ diam., hyaline wall of exciple to $10-15 \mu \mathrm{m}$ thick in lower portion and to 30-35 $\mu \mathrm{m}$ thick near the ostiole; paraphyses the same height as asci (= "hymenium" (?) to 110 $\mu \mathrm{m}$ thick), to (0.7-)0.9-1.2 $\mu \mathrm{m}$ diam./thick, paraphyse cells often with numerous oil droplets inside. Asci to (80-)110-140 × (12-)17-22 $\mu \mathrm{m}$, with 150-250 ascospores; ascospores hyaline, simple or 1-septate, $1(-2)$-guttulate, widely ellipsoid to elongate ellipsoid, sometimes somewhat clavate, $3-4(-4.5) \times(1.5-)$ $2-2.5(-3) \mu \mathrm{m}$ or spherical to $2-3.5 \mu \mathrm{m}$ in diam.

Ecology: On siliceous rocks, where growing together with species of the genera Trapelia.

Distribution: So far known only from the type locality Ulleung-do Island in South Korea, Eastern Asia.

Etymology: It is named after Ulleung-do Island, South Korea, Eastern Asia, where type collection was done.

Taxonomic notes: Thelocarpon ulleungdoense is similar to T. albidum Nyl. described from limestone of North Africa (Algeria) in having algal sheath and periphyses, but differs in having single, scattered ascomata (vs. verrucae aggregate, forming a whitish thallus without pruina), in having much thinner algal sheath (20-50 $\mu \mathrm{m}$ vs. $60-100 \mu \mathrm{m}$ thick), and in having smaller algal cells (8-12 $\mu \mathrm{m}$ vs. $11-20 \mu \mathrm{m}$ diam.), and in having narrower cortical layer (10-15 $\mu \mathrm{m}$ vs. $30-50 \mu \mathrm{m}$ thick), in having much thinner true exciple $(10-15 \mu \mathrm{m}$ vs. $50-60 \mu \mathrm{m}$ thick), in having smaller asci (140 $\mu \mathrm{m}$ vs. to $225 \mu \mathrm{m}$ long), in having much higher number of ascospores in ascus (150-250 vs. 40-80 per ascus), and in having much smaller ascospores (3-4(-4.5) $\times(1.5-) 2-2.5(-3) \mu \mathrm{m}$ vs. 11-17 $\times 5.5-9 \mu \mathrm{m})$ and in its distribution, as well as in the lack of perithecium neck (vs. to $100 \mu \mathrm{m}$ long).

Thelocarpon ulleungdoense is similar to T. intermediellum Nyl. known from the Northern Hemisphere in having globose scattered perithecia with yellow pruina. However, T. ulleungdoense differs from T. intermediellum in having well-developed algal sheath (vs. algal sheath absent or rudimentary, in having well-developed paraphyses (vs. paraphyses absent), and in having much wider ascospores $(3-4(-4.5) \times(1.5-) 2-2.5(-3) \mu \mathrm{m}$ vs. $3-4(-5) \times 1-1.5 \mu \mathrm{m})$.

Thelocarpon ulleungdoense differs from other two Korean species T. vicinellum and T. epibolum Nyl. in having algal sheath. Furthermore Thelocarpon ulleungdoense differs from T. vicinellum in having smaller ascospores (3-4 (-4.5) 

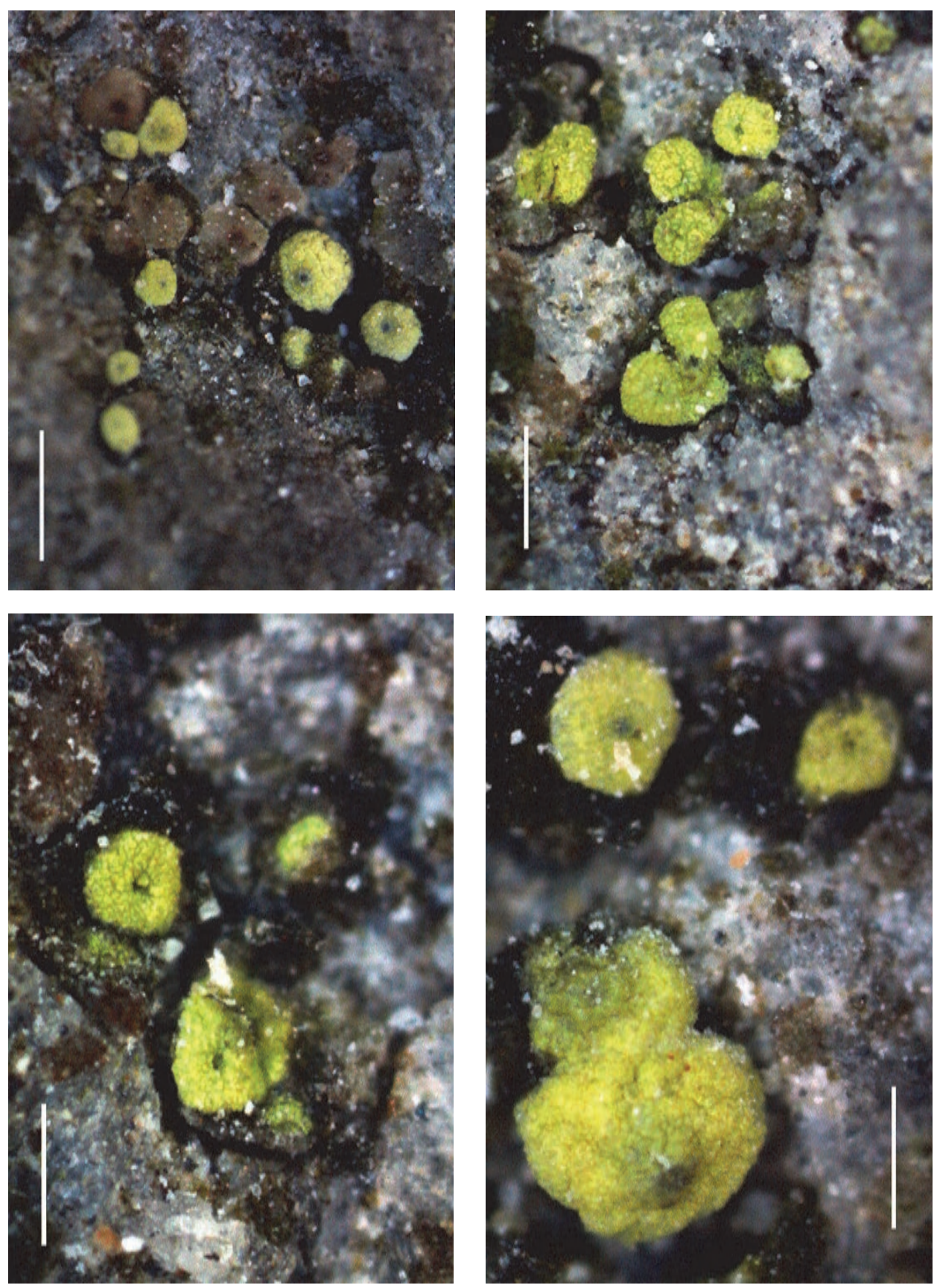

Fig. 21. Thelocarpon ulleungdoense (holotype), general habit (top), enlarged apothecia (bottom). Scales $0.5 \mathrm{~mm}$ (photo: S. Kondratyuk) 
$\times(1.5-) 2-2.5(-3) \mu \mathrm{m}$ vs. 4.5-6 × $2 \mu \mathrm{m})$, and different reaction of hymenial jelly and asci (vs. asci I+ dark blue, and hymenium jelly I-). Furthermore, Thelocarpon ulleungdoense differs from T. epibolum in having smaller ascospores (3-4($4.5) \times(1.5-) 2-2.5(-3) \mu \mathrm{m}$ vs. $4-7 \times 1.7-2 \mu \mathrm{m})$, and different reaction of hymenial jelly and asci (vs. asci I-, and hymenium jelly I+ yellow-red, rarely blue).

Thelocarpon ulleungdoense differs from T. laureri, known from Europe, Canary Islands and North America, where it grows on various substrates (stones, wood, soil, brick, leather etc.), but differs from the latter taxon in having periphyses, in having simple (vs. branched and anastomosing) paraphyses, and in having wider ascospores $(3-4(-4.5) \times(1.5-) 2-2.5(-3) \mu \mathrm{m}$ vs. $1.5-4(-6) \times 1.5-2$ $\mu \mathrm{m})$, as well as in distribution.

Additional specimen examined: Republic of Korea. Gyeongsangbuk-do, Ulleung-do Island, Ulleung-gun, Seomyeon, Taeha-ri, valley of Tae-hacheon, Seodal-gil, on siliceous rocks, growing together with Trapelia coarctata damaged by Stigmidium coarctatae. Lat.: $37^{\circ}$ 30' 12.77" N; Long.: 130 49’ 49.03" E; Alt.: 265 m a.s.l. Coll.: Kondratyuk, S. Y. and Lőkös, L., 10.07.2016 (161847_1), (KoLRI 040074 sub Trapelia coarctata).

Thelopsis loekoesii S. Y. Kondr., J. Halda et J.-S. Hur, spec. nova (Fig. 22)

Mycobank no.: MB 817986

Similar to Thelopsis rubella, but differs in having only grey to greyish green thallus, in having smaller perithecia, in having the darkest portions of perithecium around ostiole, in having less number of ascospores in ascus, in having wider periphyses, and in having longer and narrower ascospores.

Type: Republic of Korea. Gyeongsangnam-do, Sancheong-gun, Sicheon-myeon, Naedae-ri, Jirisan National Park, Georim Trail, on Quercus bark. Lat.: 35 $17^{\prime} 23.93^{\prime \prime}$ N; Long.: $127^{\circ} 42^{\prime}$ 09.85" E; Alt.: 885 m a.s.l. Coll.: Kondratyuk, S. Y., Lee, B. G. and Lőkös, L. (161137), 30.06.2016 (holotype: KoLRI 039332); the same locality, growing together with Bacidia (161133), (isotype: KoLRI 039328 sub Thelopsis).

Thallus to 10-15 cm across, crustose, very thin or endophleoid, whitishgrey to grey or greyish-greenish, with very indistinct immersed perithecia. Hypothallus not observed.

Perithecia $0.3-0.4 \mathrm{~mm}$ in diam., and to $0.4 \mathrm{~mm}$ high, scattered and discrete, usually immersed into substrate/thallus and only $1 / 4$ of ascomata seen above thalline level, sometimes thalline warts with ascomata to $0.4-0.6 \mathrm{~mm}$ diam./across can be observed, or only ostiole portion seen if perithecia totally immersed into the thallus; ostiole violetish brown or light brown with somewhat darker concentric circles in the centre (like the pupil of the eye, Fig. 22), often with open ostiole to $40 \mu \mathrm{m}$ diam. Exciple rather thick to $70-90 \mu \mathrm{m}$ thick 
at the ostiole and to $40-50 \mu \mathrm{m}$ thick in lower lateral and basal portions, hyaline throughout, only central portion to $100 \mu \mathrm{m}$ wide around the ostiole with light brownish colouration in the outermost layer or yellowish in thin outer part of the lower portion; periphyses to $30-40(-50) \mu \mathrm{m}$ long and to $2-2.5 \mu \mathrm{m}$ wide, paraphyses to $1.5 \mu \mathrm{m}$ wide towards the tips while slightly wider, $c a 2.5$ $\mu \mathrm{m}$ in lower part; subhymenium to $20-25 \mu \mathrm{m}$ thick; hymenium and subhymenium somewhat yellowish; asci multispored, with 80 ascospores, narrowly elongated to somewhat cylindrical, 140-150 × 22-27 $\mu \mathrm{m}$; ascospores 3-septate, hyaline, narrowly ellipsoid, with distinct constriction at the septa, (12-)16-21 $\times 4-5 \mu \mathrm{m}$. Pycnidia not seen.
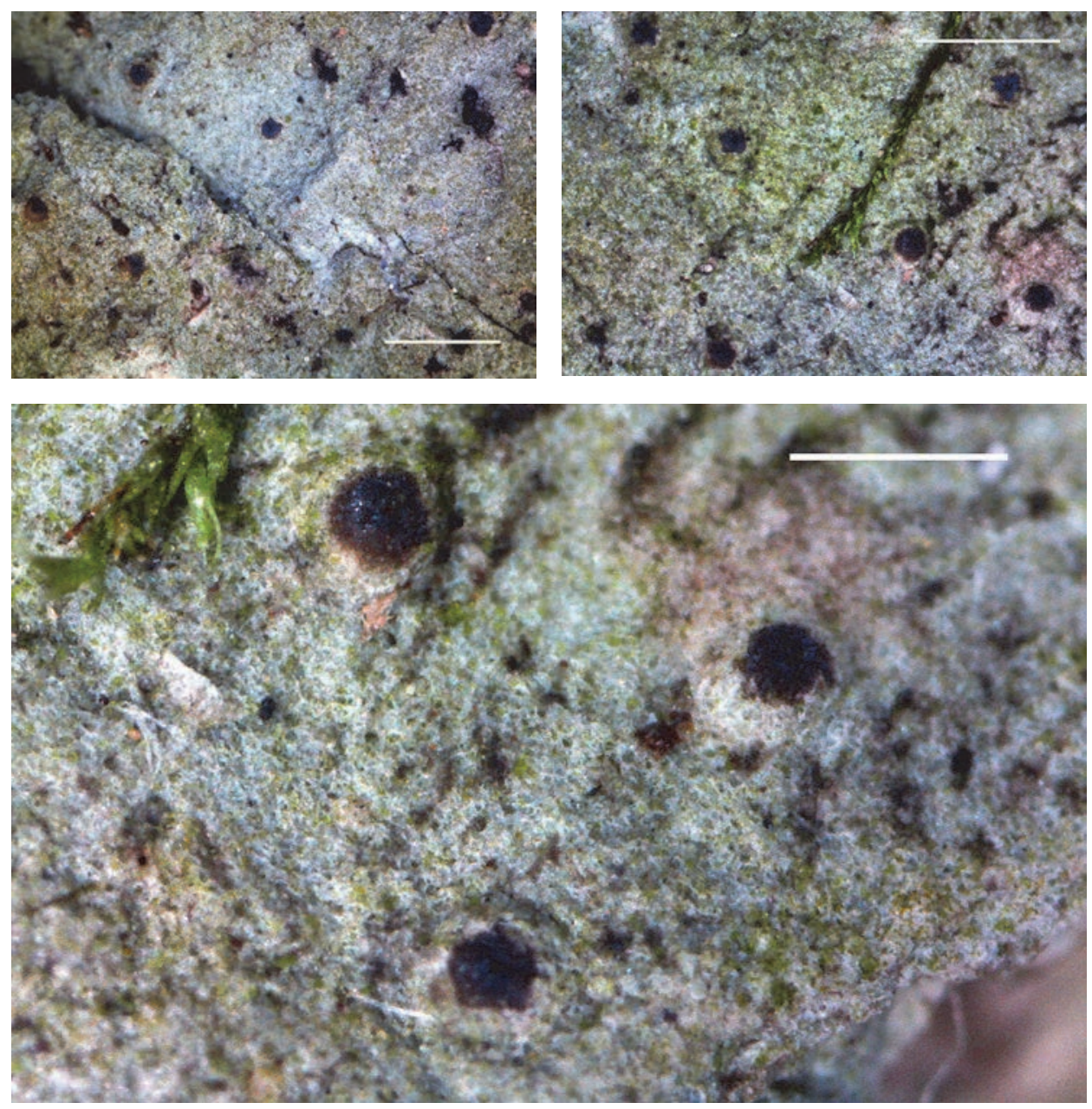

Fig. 22. Thelopsis loekoesii (holotype), general habit (top), enlarged ascomata. Scale $1 \mathrm{~mm}$ (top), $0.5 \mathrm{~mm}$ (bottom) (photo: S. Kondratyuk) 
Chemistry: Chemistry not examined.

Ecology: On bark of deciduous tree (Quercus).

Distribution: So far known only from the type locality in South Korea, Eastern Asia.

Etymology: It is named after the well-known Hungarian lichenologist and our friend László Lőkös (1959-) (Budapest, Hungary), who has collected and identified this material for the first time.

Taxonomic notes: Thelopsis loekoesii is similar to Thelopsis rubella Nyl., known from bark of mature deciduous trees of the genera Quercus, Fagus, Fraxinus, and Populus mostly in the Lobarion in ancient woodlands or parklands, where it is an important indicator species in Europe, after having brownish or brownish-reddish perithecia and after having mainly 3-septate ascospores, as well as after measurements of paraphyses and ascomatal wall, but differs in having only grey to greyish green thallus (not pale brownish), in having smaller perithecia (up to $0.4 \mathrm{~mm}$ vs. $0.4-0.6 \mathrm{~mm}$ in diam.), in having the darkest portions around ostiole (vs. perithecia dark brown or reddish brown often paler around the ostiole), in having smaller asci (140-150 × 22-27 $\mu \mathrm{m}$ vs. $150-200 \times 18-25 \mu \mathrm{m}$ ), in having less number of ascospores in ascus ( $c a$ 80 vs. $100-150$ per ascus), in having wider periphyses (to $2-2.5 \mu \mathrm{m}$ vs. to 1.5 $\mu \mathrm{m}$ thick) and in having longer and narrower ascospores $((12-) 16-21 \times 4-5$ $\mu \mathrm{m}$ vs. $12-18 \times 5-6 \mu \mathrm{m})$, after Vězda (1973) and $((10-) 12-16(-18) \times 4-8 \mu \mathrm{m})$ after Rose et al. (2009)).

Thelopsis loekoesii is similar to T. chirisanensis L. Lőkös, S. Y. Kondr. et J.-S. Hur, recently described from South Korea, Eastern Asia, but differs in having smaller perithecia (up to $0.4 \mathrm{~mm}$ vs. $0.6-0.7 \mathrm{~mm}$ in diam.), while ascomatal wall is much thicker (70-90 $\mu \mathrm{m}$ thick at the ostiole and to $40-50 \mu \mathrm{m}$ thick in lower lateral and basal portions vs. to $30 \mu \mathrm{m}$ thick at the ostiole and to 10-15 $\mu \mathrm{m}$ thick in lower portion), in having longer periphyses $(30-40(-50) \mu \mathrm{m}$ vs. 20-30 $\mu \mathrm{m}$ long), in having lower subhymenium (20-25 $\mu \mathrm{m}$ thick vs. 50-60 $\mu \mathrm{m}$ thick), in having larger number of ascospores in ascus (ca $80 \mathrm{vs} .40-60$ ascospores per ascus) and in having only 3-septate (vs. submuriform) and much narrower ascospores ((12-)16-21 × 4-5 $\mu \mathrm{m}$ vs. $(10-) 13-17 \times(6-) 6.5-7(-8) \mu \mathrm{m})$.

Thelopsis loekoesii may be similar to Strigula thelopsidoides Coppins, $\mathrm{Cl}$. Roux et Sérus. in Roux et Sérusiaux, which may resemble a diminutive Thelopsis rubella. However, Strigula thelopsidoides differs from both Thelopsis loekoesii and T. rubella in having 8-spored asci and in having smaller ascospores. Furthermore, Strigula thelopsidoides differs from Thelopsis loekoesii in having whitish or inconspicuous immersed thallus, in having orange to pale brown exciple, in having not constricted at septa, as well as much shorter and narrower ascospores $((9.5-) 10.5-13(-14.5) \times 2.5-3.5(-4.5) \mu \mathrm{m}$ vs. $(12-) 16-21 \times 4-5 \mu \mathrm{m})$. 
Additional specimen examined: Republic of Korea. Gangwon-do, Jeongseong-gun, Gangneung-si, tourist pass toward peak Seokbyeongsan, on bark, growing together with Micarea aff. stipitata and Bacidia sp. Lat.: 37 34' 38.58' N; Long.: $128^{\circ} 51^{\prime}$ 23.94" E; Alt.: $760 \mathrm{~m}$ a.s.l. Coll.: Kondratyuk, S. Y. and Lőkös, L. (150883), 10.07.2015 (KoLRI 034116 sub Micarea).

Toninia poeltiana S. Y. Kondr., L. Lőkös et J.-S. Hur, spec. nova (Fig. 23)

Mycobank no.: MB 817987

Similar to Toninia plumbina, but differs in having smaller apothecia, in having hyaline true exciple in inner part, in having hyaline subhymenium, in having thinner hymenium, in having dark bluish grey or bluish black or violet-black epihymenium, and in having 1-3-septate, as well as shorter ascospores, as well as in having K+ violetish epihymenium.

Type: Republic of Korea. Gangwon-do, Jeongseon-gun, Jeongseon-eup, Aesan-ri, Jeongseon church, on calcareous rocks, on thalli of Verrucaria fuscella (Turner) Winch, growing together with Collema sp. Lat.: $37^{\circ} 22^{\prime} 17.3^{\prime \prime} \mathrm{N}$; Long.: $128^{\circ} 40^{\prime} 25.2^{\prime \prime}$ E; Alt.: $319 \mathrm{~m}$ a.s.1. Coll.: Park, J. S., Woo, J.-J. and Lee, B. G. (152867), 06.09.2015 (holotype: KoLRI 037176).

Species non-lichenized, lichenicolous.

Apothecia (0.1-)0.15-0.3(-0.4) $\mathrm{mm}$ in diam., and to $0.1 \mathrm{~mm}$ thick while often stipe to $0.1-0.12 \mathrm{~mm}$ high observed in section; black or dark brownblack, from initial stage immarginate and semiconvex, rarely plane, soon becoming convex, epruinose; true exciple to $50 \mu \mathrm{m}$ thick in the uppermost lateral and to $30 \mu \mathrm{m}$ thick in lower lateral portions with brown or dark brown to blackish brown outermost layer (N+ violet), lacking crystals, and somewhat greyish in inner portions, to $15 \mu \mathrm{m}$ thick in basal portion, hyaline; hymenium 40-50 $\mu \mathrm{m}$ high; epihymenium to 10-15 $\mu \mathrm{m}$ thick, bluish to violet-blackish, lacking crystals, $\mathrm{K}+$ violetish, $\mathrm{N}+$ violet; paraphyses densely conglutinated, swollen towards the tips to $4 \mu \mathrm{m}$ wide, with somewhat darker surroundings around tips, but no cups observed; subhymenium 40-50 $\mu \mathrm{m}$ thick, hyaline, lacking crystals; stipe to 100-130 $\mu \mathrm{m}$ high with brownish to dark brown outermost layers and hyaline in inner portion; ascospores 1(2-)3-septate, hyaline, 13-19(-21) × (2.5-)3-4 $\mu \mathrm{m}$. Pycnidia not seen.

Chemistry: Epihymenium and outermost layer of true exciple $\mathrm{N}+$ violet, epihymenium $\mathrm{K}+$ violet. Chemistry not examined.

Ecology: On thallus of Verrucaria fuscella (Turner) Winch, mainly along edge of host thalline areoles or rarely on the upper surface of areoles, without visible damaging influence.

Distribution: So far known only from type locality in South Korea, Eastern Asia. 
Etymology: It is named after the well-known German lichenologist Josef Poelt for whom parasitic lichens were especially favourite group among lichens.

Taxonomic notes: Toninia poeltiana is similar to T. plumbina (Anzi) Hafellner et Timdal, growing on thallus of Degelia plumbea (Lightf.) P. M. Jørg. et P. James in Europe, Cyprus and Macaronesia, ranging from the Mediterranean to the low-alpine regions, but differs in having smaller apothecia (to $0.4 \mathrm{~mm}$ vs. to $0.6 \mathrm{~mm}$ in diam.), in having hyaline true exciple in inner part (vs. dark brown), in having hyaline subhymenium (vs. dark brown), in having thinner hymenium (40-50 $\mu \mathrm{m}$ vs. 50-60 $\mu \mathrm{m}$ high), in having dark bluish grey or bluish black or violet-black (not dark olivaceous green to bright green) epihymenium, and in having 1-3-septate (vs. (1-)3(-5)-septate), as well as shorter ascospores $(13-19(-21) \times(2.5-) 3-4 \mu \mathrm{m}$ vs. $18.5-29 \times 3-4.5 \mu \mathrm{m})$, as well as in having $\mathrm{K}+$ violetish epihymenium.

Toninia poeltiana is similar to T. subfuscae (Arnold) Timdal, growing in the thallus of various crustose lichens (Lecanora campestris (Schaerer) Hue, Protoparmeliopsis muralis (Schreber) M. Choisy, Lecidella scabra (Taylor) Hertel et Leuckert), in Europe ranging from about sea level to $650 \mathrm{~m}$, but differs in having smaller (to $0.4 \mathrm{~mm}$ vs. to $0.6 \mathrm{~mm}$ in diam.) and very convex (vs. plane to

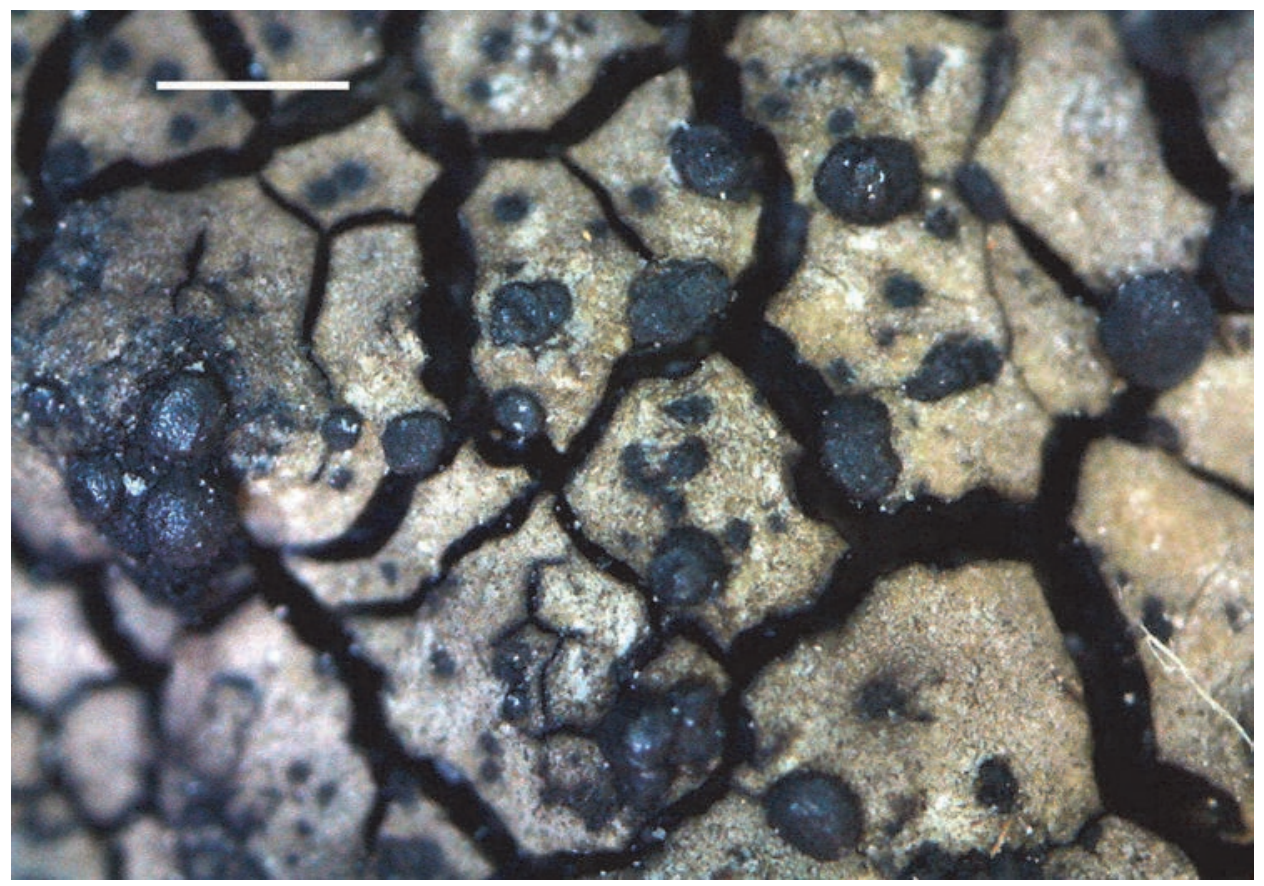

Fig. 23. Toninia poeltiana (holotype) growing on thallus of Verrucaria fuscella, general habit. Scale $0.5 \mathrm{~mm}$ (photo: S. Kondratyuk) 
weakly convex) and usually immarginate (vs. with a narrow and more or less persistent margin) apothecia, in having mainly hyaline true exciple (vs. dark reddish brown, usually with a green tinge, $\mathrm{K}-, \mathrm{N}+$ violet), in having hyaline subhymenium (vs. reddish brown), in having lower hymenium (40-50 $\mu \mathrm{m}$ vs. up to 50-60 $\mu \mathrm{m}$ high), in having dark bluish grey or blackish epihymenium (vs. olivaceous green to dark green, $\mathrm{K}-, \mathrm{N}+$ violet), in having narrower ascospores $(13-19(-21) \times(2.5-) 3-4 \mu \mathrm{m}$ vs. 9.5-16 $\times 4-5.5 \mu \mathrm{m})$, as well as in having $\mathrm{K}+$ violetish epihymenium.

Unguiculariopsis helmutii S. Y. Kondr., L. Lőkös et J.-S. Hur, spec. nova (Fig. 24)

Mycobank no.: MB 817988

Similar to Unguiculariopsis acrocordiae, but differs in having distinctly superficial ascomata, in having smaller ascomata with concave disc and prominent margin, in having brown, $K$-exciple, in having shorter excipular hairs, as well as in having longer and narrower ascospores.

Type: Republic of Korea. Jeollanam-do, Yeosu-si, Nam-myeon, Simjang-ri, Geumodo, on bark. Lat.: $34^{\circ} 30^{\prime}$ 52.5” N; Long.: $127^{\circ} 43^{\prime}$ 36.6” E; Alt.: ca 71 m a.s.l. Coll.: Kondratyuk, S. Y. (160379), 10.06.2016. (holotype: KoLRI 038524 sub Unguiculariopsis); the same locality, growing on Rinodina, growing together with Buellia, (160365), (isotype: KoLRI 038510 sub Unguiculariopsis); the same locality, on thalli of Rinodina, growing together with Buellia aff. griseovirens, (160381, 160385), (isotypes: KoLRI 038526, KoLRI 038530 sub Unguiculariopsis).

Ascomata superficial on thallus or rarely on host apothecia, brownish with whitish/greyish shade of hairs, from initial stage urn-like and very thin at the basis, then becoming more expanded, (90-)130-140(-150) $\mu \mathrm{m}$ in diam. and $80-100 \mu \mathrm{m}$ thick; when mature, disc concave to more or less, margin prominent, covered by white hairs (at more than $\times 100$ ). Exciple pale to brown, to $15-25 \mu \mathrm{m}$ thick in lateral portion, and to $20-25 \mu \mathrm{m}$ thick in basal portion, $\mathrm{N}-$, paraplectenchymatous, cells subglobose, $4-7(-8) \mu \mathrm{m}$ diam./across with conglutinate walls; excipular hairs hyaline, better seen in the uppermost portion of lateral exciple, more or less straight, without an apical hook, 5-7 long and 1.5-1.8(-2) $\mu \mathrm{m}$ wide at the basis and becoming thinner towards the tips. Subhymenium, hymenium and epihymenium hyaline or pale. Hymenium 30-40 $\mu \mathrm{m}$ high. Subhymenium to $30 \mu \mathrm{m}$ thick. Paraphyses hyaline, filiform, septate, not rarely branched in the upper part, apically not or slightly thickened. Asci clavate to subcylindrical, wall thickened near the apex, without or with an indistinct ocular chamber, I- and KI-, 8-spored, 22-45 $\times 4-8 \mu \mathrm{m}$. Ascospores hyaline, simple, ellipsoid to rather widely ellipsoid, smooth-walled, without a distinct perispore, $6-7 \times 1.5-2.2(-2.5) \mu \mathrm{m}$. Conidiomata not seen. 

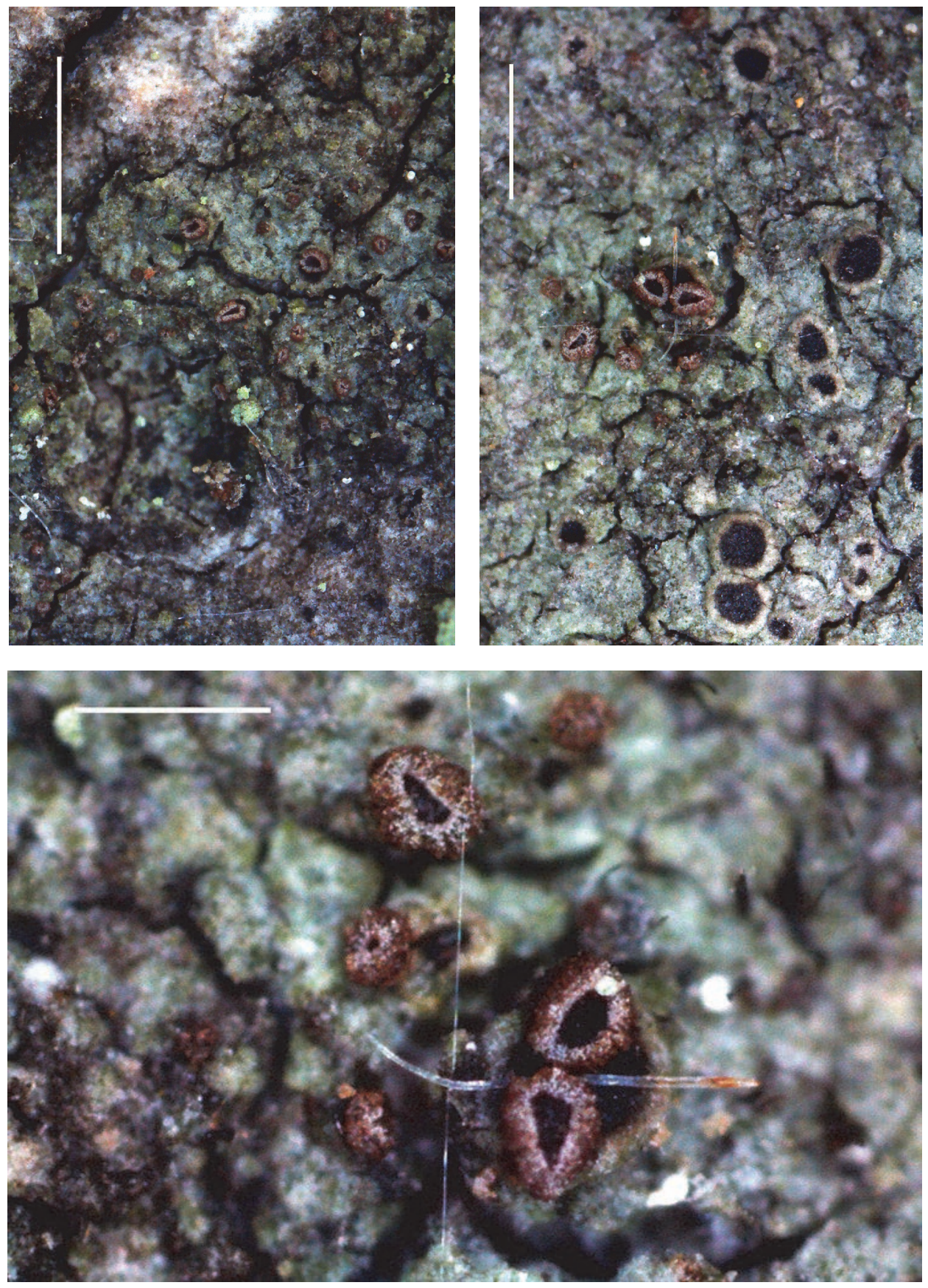

Fig. 24. Unguiculariopsis helmutii (holotype), general habit (top), enlarged ascomata (bottom). Scale $1 \mathrm{~mm}$ (top, left), $0.5 \mathrm{~mm}$ (top, right and bottom) (photo: S. Kondratyuk) 
Host: Commensalistic on Rinodina aff. sophodes (thallus and apothecia).

Distribution: It is so far known only from the type locality, in Geumo-do Island, South Korea, Eastern Asia.

Etymology: It is named after the well-known Austrian lichenologist Helmut Mayrhofer (1953-) (Graz, Austria), in recognition of his contribution to recent knowledge on members of the genus Rinodina in the world scale.

Taxonomic notes: Similar to Unguiculariopsis acrocordiae in having margin covered by whitish hairs, more or less strait, without an apical hook, and in having small ascospores, but differs in having distinctly superficial ascomata (vs. slightly immersed to superficial), in having smaller ascomata with concave disc and prominent margin (vs. when mature, disc \pm plane to slightly convex, margin prominent or not), in having brown exciple (vs. reddish to orange brown, pigment $\mathrm{K}+$ reddish, $\mathrm{N}-$ ), in having shorter excipular hairs (vs. $25-50 \times 2.5-5.5 \mu \mathrm{m}$ ), as well as in having longer and narrower ascospores (vs. $5.5-7.5 \times 2.5-3 \mu \mathrm{m})$.

Unguiculariopsis helmutii similarly to $U$. acrocordiae (after Diederich and Etayo 2000), clearly does not belong to Skyttea s. str. It strongly resembles other species of Unguiculariopsis, but is distinguished by straight, apically not hooked excipular hairs and asci with a thickened apex. However, at least four other lichenicolous species of Unguiculariopsis with straight (not hooked) excipular hairs are known: $U$. lesdainii (Vouaux) Etayo et Diederich (Diederich and Etayo 2000), U. lobariellum S. Y. Kondr. et D. J. Galloway (see Kondratyuk and Galloway 1995), U. refractiva (see Coppins 1988), and U. manriquei Etayo (see Etayo and Diederich 1996). The hairs in U. helmutii similarly to U. acrocordiae are quite variable, and some have a slightly swollen base, which is characteristic for most species of Unguiculariopsis.

\section{New combinations}

Biatora pseudosambuci (S. Y. Kondr., L. Lőkös et J.-S. Hur) S. Y. Kondr., L. Lőkös et J.-S. Hur, comb. nov., MB 817989 (Basionym: Lecanora pseudosambuci S. Y. Kondr., L. Lőkös et J.-S. Hur, Acta Botanica Hungarica 58(1-2): 81 (2016)).

Buellia pseudosubnexa (S. Y. Kondr., L. Lőkös et J.-S. Hur) S. Y. Kondr., L. Lőkös et J.-S. Hur, comb. nov., MB 817990 (Basionym: Hafellia pseudosubnexa S. Y. Kondr., L. Lőkös et J.-S. Hur, Acta Botanica Hungarica 57(3-4): 359 (2015)).

Buellia extremoorientalis (S. Y. Kondr., L. Lőkös et J.-S. Hur) S. Y. Kondr., L. Lőkös et J.-S. Hur, comb. nov., MB 817991 (Basionym: Hafellia extremorientalis S. Y. Kondr., L. Lőkös et J.-S. Hur, Acta Botanica Hungarica 57(3-4): 359 (2015)) are proposed.

Sagedia nunatakkorum (Poelt) S. Y. Kondr., comb. nov., MB 817992 (Basionym: Lecanora nunatakkorum Poelt, in Mitt. Bot. Staatssamml. München, Heft 8: 325 (1953)). 


\section{Rare or noteworthy species*}

Agonimia blumii S. Y. Kondr. - Republic of Korea. Gyeongsangnam-do, Hadong-gun, Hwagae-myeon, Jiri Mts, Yeonhacheon-Byeoksoryeong, on siliceous rock, growing together with Porpidia and Halecania santessonii. Lat.: $35^{\circ} 18^{\prime} 21.30^{\prime \prime} \mathrm{N}$; Long.: $127^{\circ} 35^{\prime} 12.84^{\prime \prime}$ E; Alt.: ca 1,473 m a.s.l. Coll.: Joshi, Y., Wang, X. Y. and Hur, J. Y. (091211), 14.10.2009 (KoLRI 011210 sub Pertusaria subfallens). - Gyeongsangnam-do, Namhae-gun, Namhae Island, Mt. Nogudwissan, on siliceous rock. Lat.: $34^{\circ} 45^{\prime} 38.6^{\prime \prime} \mathrm{N}$; Long.: $128^{\circ} 02^{\prime}$ 54.0” E; Alt.: 262 m a.s.l. Coll.: Hur, J.-S. (070955), 11.11.2007 (KoLRI 007745 sub Pertusaria flavicans). - Jeollanam-do, Gurye-gun, Masan-myeon, Jiri Mts, Nogodan-Yeonhaceon, on siliceous rock, growing together with Halecania subalpivaga. Lat.: $35^{\circ} 17^{\prime}$ 50.34" N; Long.: $127^{\circ} 33^{\prime} 11.88^{\prime \prime}$ E; Alt.: ca 1,364 m a.s.l. Coll.: Joshi, Y., Wang, X. Y. and Hur, J. Y. (091092), 13.10.2009 (KoLRI 011144 sub Pertusaria subobductans). - It was described from the Russian Far East recently (Kondratyuk 2015). New to Korea!

!Arthonia rinodinicola Candan et Halıc1 - Republic of Korea. Gyeongsangbuk-do, Ulleung-do Island, Ulleung-gun, Ulleung-eup, between Naesujeon and Soekpo waterfall, on siliceous rocks, growing on Rinodina. Lat.: $37^{\circ}$ 30' 59.62" N; Long.: 130 54' 17.54" E; Alt.: 285 m a.s.l. Coll.: Kondratyuk, S. Y. and Lőkös, L. (161646), 09.07.2016 (KoLRI 039864). - New to Korea! The second record after the type collection in Turkey (on Rinodina gennarii on calcareous rocks) (Candan and Halıc1 2009).

!Buelliella minimula (Tuck.) Fink - Republic of Korea. Gyeongsangbukdo, Ulleung-do Island, Ulleung-gun, Ulleung-eup, Dodong-ri, Seonginbong trail, on bark, on Pertusaria. Lat.: $37^{\circ} 29^{\prime} 40.6^{\prime \prime}$ N; Long.: 130 52' 26.2" E; Alt.: 855 m a.s.l. Coll.: Kondratyuk, S. Y. and Lőkös, L. (160421), 08.07.2016 (KoLRI 039634). - Gyeongsangbuk-do, Ulleung-do Island, Ulleung-gun, Ulleung-eup, Dodong-ri, Seonginbong trail, at Seonginbong peak, on bark, on Pertusaria. Lat.: 37² 29' 52.2" N; Long.: 130 52' 03.4" E; Alt.: 967 m a.s.l. Coll.: Kondratyuk, S. Y. and Lőkös, L. (161437_1), 08.07.2016. (KoLRI 039653). - Jeollanam-do, Wandogun, Bogil-myeon, Bogil Island, Buhwang-ri, Mt Gyeokjasan, on bark (Camellia), growing on thallus of Pertusaria sp. Lat.: $34^{\circ} 08^{\prime} 15.56^{\prime \prime} \mathrm{N}$; Long.: $126^{\circ} 32^{\prime}$ 09.41" E; Alt.: ca 64 m a.s.l. Coll.: Joshi, Y., Jeon, H. S. and Jeong, M. H. (100015), 05.02.2010 (KoLRI 011515 sub Buelliella). - New to Korea and new to Asia!

Caloplaca ussuriensis Oxner, S. Y. Kondr. et Elix - China. Daxinganling, Heihe county, Mt Dahei, on bark, growing together with Rinodina xanthophaea and Rinodina sp. Lat.: 50 11' 58.20" N; Long.: 126 29' 06.00" E; Alt.: ca $805 \mathrm{~m}$ a.s.l. Coll.: Hur, J.-S. and Wang, X. Y. (CH-090242), 16.08.2009 (KoLRI 010856). - New for China!

* Lichenicolous fungi are marked by an exclamation mark (!). 
!Dactylospora australis Triebel et Hertel - Republic of Korea. Gangwondo, Samcheok-si, Miro-myeon, Mt Duta, on siliceous rock, on thallus of Porpidia albocaerulescens. Lat.: $37^{\circ} 26^{\prime}$ 05.7" N; Long.: $128^{\circ} 58^{\prime}$ 47.4" E; Alt.: 1,152 m a.s.l. Coll.: Hur, J.-S. (080152), 11.05.2008 (KoLRI 008398 sub Porpidia albocaerulescens), - Gangwon-do, Yangyang-gun, Seo-myeon, Gajeonggokbong, on siliceous rock. Lat.: $37^{\circ} 52^{\prime}$ 52.80" N; Long.: $128^{\circ} 26^{\prime}$ 50.94" E; Alt.: ca 1,101 m a.s.l. Coll.: Joshi, Y., Wang, X. Y. and Ryu, J. A. (090626), 22.05.2009 (KoLRI 010295 sub Porpidia albocaerulescens). - Gangwon-do, Yangyang-gun, Seo-myeon, Hwangi-ri, Mt Jobong, on siliceous rock. Lat.: $37^{\circ} 56^{\prime} 06.42^{\prime \prime}$ N; Long.: $128^{\circ} 33^{\prime}$ 44.82" E; Alt.: $980 \mathrm{~m}$ a.s.l. Coll.: Joshi, Y., Wang, X. Y., Ryu, J. A. and Hur, J. Y. (090238), 14.05.2009 (KoLRI 009993 sub Porpidia albocaerulescens). Gyeongsangnam-do, Sancheong-gun, Sancheong-eup, Jiri Mts, Mt Ungseok, on siliceous rock. Lat.: $35^{\circ} 22^{\prime}$ 59.2" N; Long.: $127^{\circ}$ 51' 27.1" E; Alt.: $837 \mathrm{~m}$ a.s.l. Coll.: Hur, J.-S. (070895), 16.10.2007 (KoLRI 012836 sub Porpidia albocaerulescens). - Jeollanam-do, Gurye-gun, Masan-myeon, Jiri Mts, Hwaeom valley,

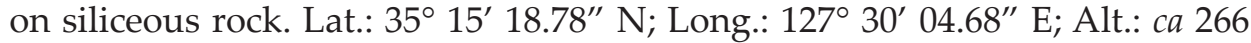
m a.s.l. Coll.: Joshi, Y., Wang, X. Y. and Hur, J. Y. (090992), 12.10.2009 (KoLRI 006872 sub Porpidia albocaerulescens). - Jeollanam-do, Gurye-gun, Toji-myeon, Jiri Mts, Piagol, Jangteomok, on siliceous rock. Lat.: $35^{\circ} 19^{\prime} 06.2^{\prime \prime}$ N; Long.: $127^{\circ} 40^{\prime}$ 50.1" E; Alt.: 1,559 m a.s.l. Coll.: Hur, J.-S. (060940), 29.09.2006 (KoLRI 005324 sub Porpidia albocaerulescens). - New to Korea!

!Endococcus propinguus (Körb.) D. Hawksw. - Republic of Korea. Gyeongsangbuk-do, Ulleung-do Island, Ulleung-gun, Ulleung-eup, Dodong-ri, Seonginbong trail, on siliceous rocks, growing on Porpidia albocaerulescens. Lat.: $37^{\circ}$ $29^{\prime} 30.00^{\prime \prime}$ N; Long.: 130 53' 10.88" E; Alt.: 565 m a.s.l. Coll.: Kondratyuk, S. Y. and Lőkös, L. (161497), 08.07.2016 (KoLRI 039715). - New to Korea.

Halecania santessonii Andreev - Republic of Korea. Chungcheongbukdo, Danyang-gun, Gagok-myeon, Sobaeksan Mts, on siliceous rock. Lat.: $36^{\circ} 57^{\prime} 45.6^{\prime \prime}$ N; Long.: $128^{\circ} 30^{\prime}$ 29.3" E; Alt.: ca 1,149 m a.s.l. Coll.: Hur, J.-S. (070487), 11.06.2007 (KoLRI 007339 sub Porpidia albocaerulescens). - Gangwondo, Yangyang-gun, Seo-myeon, Jeombongsan Mts, Galjeongokbong, on siliceous rock, Lat.: $37^{\circ} 52^{\prime}$ 57.12" N; Long.: $128^{\circ}$ 30' 09.66" E; Alt.: ca 1,104 m a.s.l. Coll.: Joshi, Y., Wang, X. Y. and Ryu, J. A. (090593), 22.05.2009 (KoLRI 010271 sub Porpidia albocaerulescens). - Gyeongsangbuk-do, Ulleung-do Island, Ulleung-gun, Ulleung-eup, between Naesujeon and Soekpo waterfall, at a rockwall, on siliceous rocks, on Pertusaria. Lat.: $37^{\circ} 31^{\prime} 19.51^{\prime \prime} \mathrm{N}$; Long.: $130^{\circ}$ 54' 16.03" E; Alt.: $415 \mathrm{~m}$ a.s.l. Coll.: Kondratyuk, S. Y. and Lőkös, L. (161762), 09.07.2016 (KoLRI 039980). - Gyeongsangnam-do, Hadong-gun, Hwagae-myeon, Jiri Mts, Byeoksoryeong-Seseok, on siliceous rock. Lat.: $35^{\circ} 19^{\prime} 40.74^{\prime \prime} \mathrm{N}$; Long.: $127^{\circ} 39^{\prime} 31.32^{\prime \prime}$ E; Alt.: ca 1,346 m a.s.l. Coll.: Joshi, Y., Wang, X. Y. and Hur, J. Y. (091375), 15.10.2009 (KoLRI 011297 sub Porpidia albocaerulescens). 
- Gyeongsangnam-do, Hadong-gun, Hwagae-myeon, Jiri Mts, YeonhaceonByeoksoryeong, on siliceous rock, growing together with Agonomia aff. blumii and Porpidia. Lat.: $35^{\circ} 18^{\prime} 21.30^{\prime \prime}$ N; Long.: $127^{\circ} 35^{\prime} 12.84^{\prime \prime}$ E; Alt.: ca 1,473 m a.s.l. Coll.: Joshi, Y., Wang, X. Y. and Hur, J. Y. (091211), 15.10.2009 (KoLRI 011210 sub Pertusaria subfallens). - Jeju-do Prov., Cheju-do Island, Jeju-si, Mt Hallasan, Hallasan National Park, Gwaneumsa trail, on siliceous rock. Lat.: $33^{\circ} 23^{\prime} 37.04^{\prime \prime}$ N; Long.: $126^{\circ} 32^{\prime} 16.01^{\prime \prime}$ E; Alt.: 1,072 m a.s.l. Coll.: Oh, S.-O., Jayalal, U., Park, J. S. and Hur, J.-S. (121058-1), 01.06.2012 (KoLRI-016091 sub Porpidia). - This species was so far known from several localities in the Russian Far East (Primorsky Region) (Andreev 2010). New to Korea!

!Laeviomyces aff. fallaciosus Hafellner et Kalb - Republic of Korea. Gyeongsangbuk-do, Ulleung-do Island, Ulleung-gun, Ulleung-eup, Jeodongri, Seonginbong trail at the KBS aerial, on beton, on the thallus of Sarcogyne regularis. Lat.: $37^{\circ} 29^{\prime} 11.77^{\prime \prime}$ N; Long.: 130 53' 33.37" E; Alt.: $280 \mathrm{~m}$ a.s.l. Coll.: Kondratyuk, S. Y. and Lőkös, L. (161507), 08.07.2016 (KoLRI 039725). - New to Korea!

Lecanora albescens (Hoffm.) Branth et Rostr. - Republic of Korea. Gangwon-do, Jeongseon-gun, Jeongseon-eup, Aesan-ri, Jeongseon church, on calcareous rock, growing together with Rusavskia coreana, Thyrea sp., Acarospora. Lat.: $37^{\circ} 22^{\prime} 17.3^{\prime \prime} \mathrm{N}$; Long.: $128^{\circ} 40^{\prime} 25.2^{\prime \prime}$ E; Alt.: 319 m a.s.l. Coll.: Lee, B. G. (152796), 06.09.2015 (KoLRI 037783). - New to Korea!

Lecanora layana Lendemer - Republic of Korea. Gangwon-do, Jeongseon-gun, Bukpyeong-myeon, Mt Baekseokbong, on bark. Lat.: $37^{\circ} 28^{\prime} 44.34^{\prime \prime}$ $\mathrm{N}$; Long.: $128^{\circ}$ 39' 45.60" E; Alt.: $494 \mathrm{~m}$ a.s.l. Coll.: Joshi, Y., Wang, X. Y., Ryu, J. A. and Hur, J. Y. (090440, 090455), 16.05.2009 (KoLRI-010146, KoLRI 010158). Jeju-do, Cheju-do Island, Jeju-si, Mt Hallasan, Hallasan National Park, Seongpanak trail, along the tourist path, on bark of deciduous trees. Lat.: $33^{\circ} 22^{\prime}$ 38.8" N; Long.: $126^{\circ} 34^{\prime} 16.4^{\prime \prime}$ E; Alt.: 1,181 m a.s.l. Coll.: Kondratyuk, S., Hur, J.-S., Oh, S.-O. and Kusama, Y. (121666), 07.08.2012 (KoLRI 016981 sub Lecanora). - Jeollabuk-do, Jinan-gun, Sungsu-myeon, on bark. Lat.: $35^{\circ} 41^{\prime} 33.54^{\prime \prime}$ N; Long.: $129^{\circ} 21^{\prime} 12.75^{\prime \prime}$ E; Alt.: 725 m a.s.l. Coll.: Lee, B. G. ['Jinan 18'], Woo, J.-J., 22.05.2016 (KoLRI). - Jeollanam-do, Suncheon-si, Songgwang-myeon, Sinpyeong-ri, Songgwangsa 12, on bark. Lat.: $35^{\circ} 00^{\prime} 07.3^{\prime \prime}$ N; Long.: $127^{\circ} 16^{\prime}$ 29.3" E; Alt.: 220 m a.s.l. Coll.: Park, J. S., Woo, J.-J. and Lee, B. G. (160107), 08.05.2016 (KoLRI 038067). - Jeollanam-do, Wando-gun, Bogil-myeon, Bogildo Island, Jungtong-ri, Bogil elementary school, 379-1, on bark. Lat.: 34 $04^{\circ}$ 44.3" N; Long.: $126^{\circ} 33^{\prime} 20.4^{\prime \prime}$ E; Alt.: 7 m a.s.l. Coll.: Park, J. S., Woo, J.-J. and Lee, B. G. (160068), 06.05.2016 (KoLRI 038028). - It was recently described from North America (Lendemer 2015). Molecular data confirming status of Korean material will be published elsewhere. New to Korea, new to Asia! 
Lecidella scabra (Taylor) Hertel et Leuckert - Republic of Korea. Gyeongsangbuk-do, Ulleung-do Island, Ulleung-gun, Ulleung-eup, between Naesujeon and Soekpo waterfall, near shelter house, on siliceous rocks. Lat.: $37^{\circ} 31^{\prime}$ 09.53" N; Long.: 130 54' 13.17" E; Alt.: $280 \mathrm{~m}$ a.s.l. Coll.: Kondratyuk, S. Y. and Lőkös, L. (161721), 09.07.2016 (KoLRI 039939). - New to Korea!

Megaspora rimisorediata Valadbeigi et A. Nordin - China. Xinjiang province, Urumqi city, Mt Tian, on trunk, growing together with Seirophora orientalis, Caloplaca neobaltistanica and Caloplaca sp. 18. Lat.: $43^{\circ} 53^{\prime} 20.9^{\prime \prime}$ N; Long.: 88 07' 05.7" E; Alt.: ca 1,962 m a.s.l. Coll.: Oh, S.-O. and Hur, J.-S. (CH-130095), 15.07.2013 (KoLRI 019172 sub Caloplaca neobaltistanica); the same locality, growing together with Megaspora verrucosa, Caloplaca neobaltistanica, Caloplaca aff. chlorina, Lecidella cf euphorea, Anaptychia, Rinodina, and Caloplaca sp., (CH-130099), (KoLRI 019176 sub Caloplaca aff. chlorina). - Xinjiang province, Uygur, Wutonggou (Wutong valley), on branches, growing together with Caloplaca cerinella aggr. Lat.: $44^{\circ} 23^{\prime} 24.9^{\prime \prime} \mathrm{N}$; 87 52' 06.0” E; Alt.: ca $438 \mathrm{~m}$ a.s.l. Coll.: Oh, S.-O. and Hur, J.-S. (CH-130172), 17.07.2013 (KoLRI 019249 sub Caloplaca cerinella aggr.); the same locality, growing together with Caloplaca cerinella, Caloplaca sp. 27, and C. zoroasteriorum, (CH-130167), (KoLRI 019244 sub Caloplaca cerinella); the same locality, on soil, growing together with Caloplaca tominii and cyanolichen, (CH 130155), (KoLRI 019232); the same locality, on soil, growing together with Caloplaca tominii, Peltula and Endocarpon, $(\mathrm{CH}-$ 130152), (KoLRI 019229 sub Peltula). - New to China.

Micarea farinosa Coppins - Republic of Korea. Gangwon-do, Gangneungsi, Jeongseong-gun, tourist pass toward peak Seokbyeongsan, on bark. Lat.: $37^{\circ} 34^{\prime} 38.58^{\prime \prime}$ N; Long.: $128^{\circ} 51^{\prime} 23.94^{\prime \prime}$ E; Alt.: ca 760 m a.s.l. Coll.: Kondratyuk, S. Y. and Lőkös, L. (150882), 10.07.2015 (KoLRI 034115). - New to Korea, new to Asia!

!Minutoexcipula aff. mariana V. Atienza - Republic of Korea. Gyeongsangbuk-do, Ulleung-do Island, Ulleung-gun, Ulleung-eup, Dodong-ri, Seonginbong trail, at Seonginbong peak, on bark, on thallus of steril Pertusaria sp. Lat.: 37²9' 52.18" N; Long.: $130^{\circ} 52^{\prime}$ 03.11" E; Alt.: 948 m a.s.l. Coll.: Kondratyuk, S. Y. and Lőkös, L. (161485), 08.07.2016 (KoLRI 039703). - New to Korea!

Opegrapha anomaea Nyl. - Republic of Korea. Gangwon-do, Sokchosi, Mt Seorak, on bark (Acer), growing together with Lecanora sp. and Biatora longispora. Lat.: $38^{\circ} 07^{\prime}$ 09.9" N; Long.: $128^{\circ} 27^{\prime} 37.1^{\prime \prime}$ E; Alt.: 1,500 m a.s.l. Coll.: Hur, J.-S. (041584), 12.10.2004 (KoLRI 002378 sub Pertusaria laeviganda). - Jeollanam-do Prov., Jindo-gun, Hacho-do Island, on siliceous rocks, on thalli of Pertusaria sp. Lat.: $34^{\circ} 19^{\prime}$ 05.0” N; Long.: $126^{\circ} 02^{\prime} 22.9^{\prime \prime}$ E; Alt.: 3 m a.s.l. Coll.: Wang, X. Y. and Ryu, J. A. (110883), 23.10.2011 (KoLRI 013877 sub Opegrapha). - New to Korea! It is the second record of this species from Asia (see Zhur- 
benko and Kobzeva 2014). Pertusaria laeviganda is for the first time recorded as host of this lichenicolous fungus. Data on conidiomata and conidia for this species were hitherto missing (Ertz et al. 2004). They are provided here for $O$. anomea for the first time. Conidiomata was richly present in Korean specimen 110883 (KoLRI 013877). Conidiomata was observed in the same stromatic formation with ascomata as immersed to 150-170 $\mu \mathrm{m}$ diam. and to 130-150 $\mu \mathrm{m}$ high among ascomata, which were slightly smaller ( to $100 \mu \mathrm{m}$ diam. and to $150 \mu \mathrm{m}$ high). Conidia narrowly bacilliform, 3.5-4 × 0.5-0.7 $\mu \mathrm{m}$.

Opegrapha aff. xerica Torrente et Egea - Republic of Korea. Jeju-do Prov., Cheju-do Island, Seogwipo-si, Donnaeko-ro, Donnaeko, on bark. Lat.: $33^{\circ} 18^{\prime}$ 04.3" N; Long.: $126^{\circ} 34^{\prime}$ 53.07" E; Alt.: 330 m a.s.l. Coll.: Kondratyuk, S. Y. (140616-2), 19.06.2014 (KoLRI 023012). - New to Korea! This taxon is in urgent need of the further revision with inclusion of additional specimens. Within future revision this taxon should be compared with Opegrapha intertexta C. Knight described from New Zealand as well.

Phoma aff. lecanorina Diederich - Republic of Korea. Jeju-do Prov., Cheju-do Island, Jeju-si, Hallim-eup, Gwideok-ri, coast near the Chorok village, on rock, on thalli Protoparmeliopsis muralis. Lat.: $33^{\circ} 26^{\prime} 33.3^{\prime \prime} \mathrm{N}$; Long.: $126^{\circ} 17^{\prime}$ 00.1" E; Alt.: ca 18 m a.s.l. Coll.: Kondratyuk, S. Y., Lőkös, L., Oh, S.-O., Jayalal, U., Joshi, S., Park, J. S. and Hur, J.-S. (121367), 05.07.2012 (KoLRI 016424 sub Protoparmeliopsis muralis). - New to Korea! It is the second record for species described from Luxembourg (Europe) from Lecanora expallens (Diederich 1986). However, it should be mentioned that our specimen differs in having slightly longer and much wider conidia and in having different host. Furthermore our specimen was insufficient to be selected as type specimen of a new taxon.

!Polycoccum rubellianae Calatayud et V. Atienza - Republic of Korea. Jeollanam-do, Goheung-gun, Geumsanmyeon, Geogeum-do Island, Sinpyeong-ri coast, on siliceous rock, on Buellia cf. stellulata, growing together with Jasonhuria bogilana, Aspicilia sp., Xanthoparmelia coreana damaged by Lichenostigma cosmopolites. Lat.: 34 28' 30.4" N; Long.: $127^{\circ} 14^{\prime}$ 03.6" E; Alt.: 1 m a.s.l. Coll.: Jayalal, U., Park, J. S. and Ryu, J. A. (120073), 17.04.2012 (KoLRI 140666 sub Buellia stellulata). - New to Korea, new to Asia!

Porina nucula Ach. - Republic of Korea. Jeollanam-do, Wando-gun, Bogil-myeon, Bogil-do Island, Mt Gyeokjasan, on siliceous rock. Lat.: $34^{\circ} 08^{\prime}$ 42.34" N; Long.: 126 33' 14.39" E; Alt.: ca $141 \mathrm{~m}$ a.s.l. Coll.: Joshi, Y., Jeon, H. S. and Jeong, M. H. (100037), 05.02.2010 (KoLRI 011537 sub Porina). - New to Korea! This species differs from all Porina species in having very wide ascospores and presence of halo.

!Pyrenidium actinellum Nyl. - Republic of Korea. Gyeonsangbuk-do, Sangju-si, Naeseo-myeon, deciduous forest, on siliceous rock, on edge/own 
margins of apothecia of Porpidia albocaerulescens. Lat.: $36^{\circ} 26^{\prime} 45.1^{\prime \prime} \mathrm{N}$; Long.: $126^{\circ} 01^{\prime}$ 34.4" E; Alt.: 320 m a.s.l. Coll.: Lee, B. G., Woo, J.-J. and Park, J. S., 23.05.2016. - Gyeongsangbuk-do, Ulleung-do Island, Ulleung-gun, Ulleungeup, between Naesujeon and Soekpo waterfall, at a rockwall, on siliceous rocks, on thallus of Porpidia albocaerulescens, growing together with Lepraria sp. Lat.: 37 31' 19.51" N; Long.: 130 54' 16.03" E; Alt.: $415 \mathrm{~m}$ a.s.l. Coll.: Kondratyuk, S. Y. and Lőkös, L. (161737), 09.07.2016 (KoLRI 039955 sub Porpidia); the same locality, on thallus of Porpidia albocaerulescens, growing together with Lepraria spp. (161738), (KoLRI 039956 sub Porpidia). - New to Korea!

Rhexophiale rhexoblephara (Nyl.) Hellb. - Republic of Korea. Gangwondo, Gangneung-si, Jeongseong-gun, tourist pass toward peak Seokbyeongsan, on bark. Lat.: $37^{\circ} 34^{\prime} 41.82^{\prime \prime}$ N; Long.: $128^{\circ}$ 51' 37.65" E; Alt.: ca $810 \mathrm{~m}$ a.s.l. Coll.: Kondratyuk, S. Y. and Lőkös, L. (151010, 151011, 151013), 10.07.2015 (KoLRI 034243, KoLRI 034244, KoLRI 034246 sub Biatora longispora); the same locality, growing together with Biatora longispora, Verseghya klarae, and Scoliciosporum, (151015), (KoLRI 034248 sub Biatora longispora); the same locality, Lat.: $37^{\circ} 34^{\prime} 36.55^{\prime \prime} \mathrm{N}$; Long.: $128^{\circ}$ 51' 47.16" E; Alt.: ca $840 \mathrm{~m}$ a.s.l. (151066), (KoLRI 034299 sub Biatora longispora); the same locality, growing together with Rinodina xanthophaea, and Biatora longispora, (151101), (KoLRI $034334 \mathrm{sub}$ Rinodina xanthophaea); the same locality, Lat.: $37^{\circ} 34^{\prime} 46.37^{\prime \prime} \mathrm{N}$; Long.: $128^{\circ} 52^{\prime}$ 05.02" E; Alt.: ca $850 \mathrm{~m}$ a.s.l. (151151), (KoLRI 034384 sub Lecanora); the same locality, growing together with Bacidia and Lecanora spp., (151168), (KoLRI 034401 sub Lecanora). - Gangwon-do, Gangneung-si, Mt Seokbyeongsan, on bark, growing together with Pertusaria amara and Biatora longispora. Lat.: $37^{\circ}$ 34' 38.5" N; Long.: 128 51' 24.2" E; Alt.: 763 m a.s.l. Coll.: Park, J. S. (151752), 10.07.2015 (KoLRI 034744 sub Pertusaria amara). - Gangwon-do, Gangneungsi, Wangsan-myeon, Korea forest seed and variety centre of Gangreung office, on bark. Lat.: $37^{\circ} 35^{\prime} 23.40^{\prime \prime}$ N; Long.: $128^{\circ} 48^{\prime} 41.72$ " E; Alt.: 876 m a.s.l. Coll.: Jayalal, R. U. G., Park, J. S. and Woo, J.-J. (141359), 16.07.2014 (KoLRI 023813 sub Lecanora imshaugii). - New to Korea!

Rimularia badioatra (Krempelh.) Hertel et Rambold - Republic of Korea. Jeju-do, Cheju-do Island, Seogwipo-si, Yeongcheon-dong, on siliceous rock. Lat.: $33^{\circ} 18^{\prime} 01.7^{\prime \prime} \mathrm{N}$; Long.: $126^{\circ} 34^{\prime} 34.7^{\prime \prime}$ E; Alt.: $278 \mathrm{~m}$ a.s.l. Coll.: Oh, S.-O. and Liu, D. (152453), 18.08.2015 (KoLRI 036675). - New to Korea!

Rinodina confragosa (Ach.) Körb. - Republic of Korea. Jeollanam-do, Wando-gun, Saengil-myeon, Saengil-do Island, Geumgok-ri coast, on rock. Lat.: $34^{\circ} 20^{\prime} 02.02^{\prime \prime} \mathrm{N}$; Long.: $126^{\circ} 57^{\prime}$ 51.02" E; Alt.: 7 m a.s.l. Coll.: Jayalal, U., Park, J. S. and Ryu, J. A. (120188), 18.04.2012 (KoLRI 014782 sub Aspicilia caesiocinerea). - New to Korea!

Rinodina milvina (Wahlenb.) Th. Fr. - Republic of Korea. Jeju-do Prov., Jeju-si, Chuja-do Island, Chuja-myeon, Yecho-ri, Port of Yecho-ri, on siliceous 
rock, growing together with Buellia chujadoensis. Lat.: $33^{\circ} 57^{\prime} 22.4^{\prime \prime} \mathrm{N}$; Long.: $126^{\circ} 20^{\prime}$ 03.54" E; Alt.: ca $40 \mathrm{~m}$ a.s.l. Coll.: Halda, J. P. (141099), 21.06.2014 (KoLRI 023657 sub Buellia spuria). - New to Korea!

Rinodina occulta (Körb.) Sheard - Republic of Korea. Jeollanam-do, Wando-gun, Bogil-myeon, Bogil-do Island, Mt Gyeokjasan, between Keungiljae and Suribong, on siliceous rock, growing together with Pertusaria corallina and Candelariella corallina. Lat.: $34^{\circ} 08^{\prime} 34.06^{\prime \prime} \mathrm{N}$; Long.: $126^{\circ} 32^{\prime} 12.51^{\prime \prime} \mathrm{E}$; Alt.: ca 346 m a.s.l. Coll.: Joshi, Y., Jeon, H. S., Jeong, M. H. (100140), 05.02.2010, (KoLRI 011637 sub Pertusaria corallina). - New to Korea!

Rinodina xanthophaea (Nyl.) Zahlbr. - China. Daxinganling, Heihe county, Mt Dahei, on bark, growing together with Rinodina sp. Lat.: 50 $11^{\prime}$ 58.20" N; Long.: $126^{\circ} 29^{\prime}$ 06.00" E; Alt.: ca 805 m a.s.l. Coll.: Hur, J.-S. and Wang, X. Y. (CH-090242), 16.08.2009 (KoLRI 010856 sub Caloplaca ussuriensis); the same locality, Lat.: 50 11' 33.24" N; Long.: $126^{\circ} 28^{\prime}$ 20.22" E; Alt.: ca $831 \mathrm{~m}$ a.s.l. (CH-090274), (KoLRI 010888). - New to China!

Rusavskia dasanensis S. Y. Kondr., I. Galanina et J.-S. Hur - China. Xinjiang province, Urumqi city, Mt Tian, on rock. Lat.: $43^{\circ} 53^{\prime} 34.5^{\prime \prime} \mathrm{N}$; Long.: $88^{\circ}$ 06' 23.9" E; Alt.: ca 2,094 m a.s.l. Coll.: Oh, S.-O. and Hur, J.-S. (CH-130055), 14.07.2013 (KoLRI 019131). - New to China! This species was recently described from several Eurasian countries (Kondratyuk et al. 2013b).

!Tremella phaeophysciae Diederich et M. S. Christ - Republic of Korea. Gangwon-do, Gangneung-si, Mt Seokbyeongsan, on bark, growing together with Pertusaria, Lecidella and Rinodina spp. Lat.: $37^{\circ} 34^{\prime} 38.5^{\prime \prime}$ N; Long.: $128^{\circ} 51^{\prime}$ 50.8” E; Alt.: 855 m a.s.l. Coll.: Park, J. S. (151794), 10.07.2015 (KoLRI 034793 sub Pertusaria sp.); the same locality, growing together with Pertusaria, Lecidella and Myelochroa spp., (151796), (KoLRI 034795 sub Pertusaria sp.). - Gangwon-do, Gangneung-si, Mt Seokbyeongsan, on bark, growing together with Pertusaria, and Phaeophyscia spp. Lat.: $37^{\circ} 34^{\prime} 41.3^{\prime \prime}$ N; Long.: $128^{\circ} 51^{\prime} 55.9^{\prime \prime}$ E; Alt.: 872 m a.s.l. Coll.: Park, J. S. (151802), 10.07.2015 (KoLRI 034802 sub Pertusaria sp.). - Gyeongsangnam-do, Sancheong-gun, Sancheong-eup, along the tourist path to Ungseokbong, on bark (Robinia), growing together with Biatora longispora and Phaeophyscia. Lat.: $35^{\circ} 22^{\prime} 41.74^{\prime \prime} \mathrm{N}$; Long.: $127^{\circ} 52^{\prime} 21.93^{\prime \prime}$ E; Alt.: 324 m a.s.l. Coll.: Kondratyuk, S. Y. and Lőkös, L. (150239), 22.06.2015 (KoLRI 033834 sub Biatora longispora). - Jeollabuk-do, Muju-gun, Mupungmyeon, Mt Daedeok, on bark (Quercus), on thallus of Phaeophyscia adiastola, growing together with Caloplaca subflavorubescens. Lat.: $35^{\circ} 55^{\prime} 34.7^{\prime \prime} \mathrm{N}$; Long.: $127^{\circ} 52^{\prime}$ 58.4" E; Alt.: 1,265 m a.s.l. Coll.: Woo, J.-J., Jang, S. H. and Oh, S.-O. (150198), 19.06.2015 (KoLRI 035746 sub Phaeophyscia). - Jeollabuk-do, Mujugun, Seolcheon-myeon, Mt Sambong, on bark (Quercus), on thallus of Phaeophyscia adiastola. Lat.: $35^{\circ}$ 52' 20.3" N; Long.: $127^{\circ} 49^{\prime} 36.6^{\prime \prime}$ E; Alt.: 939 m a.s.l. Coll.: Woo, J.-J., Jang, S. H. and Oh, S.-O. (150002), 18.06.2015 (KoLRI 035548 
sub Phaeophyscia adiastola). - Jeollabuk-do, Namwon-si, Ayeong-myeon, Gusang-ri, Mt Bonghwa, on bark (Quercus), growing together with Pertusaria, Biatora longispora and Rinodina sp., Lat.: 35 32' 17.1" N; Long.: $127^{\circ} 34^{\prime} 18.8^{\prime \prime}$ E; Alt.: 723 m a.s.l. Coll.: Woo, J.-J. and Oh, S.-O. (152203), 17.07.2015 (KoLRI 036126 sub Pertusaria sp.). - New to Korea!

Verseghya klarae S. Y. Kondr., L. Lőkös et J.-S. Hur - Russia. Primorsky region, Khasan district, "Zemlia Leoparda" (= Leopard Land) Federal Nature Park, "Kedrovaya padj" reserve, along the pass to the Second Golden Stream, deciduous forest, on bark growing together with Bacidia sp., and Pyrenula sp. Lat.: $43^{\circ} 06^{\prime}$ 52.5” N; Long.: 131 31' 00.1" E; Alt.: ca $144 \mathrm{~m}$ a.s.l. Coll.: Kondratyuk, S., Oh, S.-O. and Hur, J.-S. (RU 130449), 06.08.2013 (KoLRI 019976 sub Versegyha klarae). - It was recently described from Korea (Kondratyuk et al. 2016a). New to Russia!

Xanthoria splendens (Darb.) Poelt - China. Xinjiang province, Urumqi

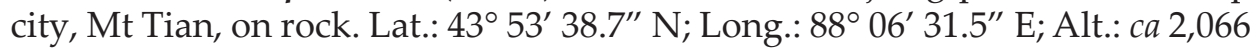
m a.s.l. Coll.: Oh, S.-O. and Hur, J.-S. (CH-130029), 14.07.2013 (KoLRI 019105). - New to China!

Zeroviella coreana (S. Y. Kondr. et J.-S. Hur) S. Y. Kondr. et J.-S. Hur China. Daxinganling, Heihe County, Mt Xifeng, on rock, growing together with Lecanora polytropa. Lat.: 50 34' 57.60" N; Long.: $127^{\circ} 09^{\prime} 33.18^{\prime \prime}$ E; Alt.: ca $220 \mathrm{~m}$ a.s.l. Coll.: Hur, J.-S. and Wang, X. Y. (CH-090298), 17.08.2009 (KoLRI 010912 sub Zeroviella). - It was recently described from South Korea (Kondratyuk et al. 2015a). New to China!

Zeroviella esfahanensis S. Y. Kondr., B. Zarei-Darki et J.-S. Hur - China. Daxinganling, Heihe county, Mt Xifeng, on rock, growing together with Le-

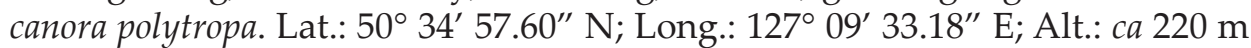
a.s.l. Coll.: Hur, J.-S. and Wang, X. Y. (CH-090301), 17.08.2009 (KoLRI 010915 sub Lecanora polytropa). - Inner Mongolia, Duolun county, Shisanlitan, on rock, growing together with Protoparmeliopsis of muralis and Rhizoplaca. Lat.: $42^{\circ} 01^{\prime} 0.66^{\prime \prime} \mathrm{N}$; Long.: $116^{\circ} 17^{\prime} 44.28^{\prime \prime}$ E; Alt.: ca 1,434 m a.s.l. Coll.: Hur, J.-S. and Wang, X. Y. (CH-090333), 08.08.2009 (KoLRI 010947 sub Zeroviella). - Inner Mongolia, Xilin county, Mountain, on rock, growing together with Sedelnikovaea baikalensis, Lecanora frustulosa aggr., and Aspicilia damaged by Lichenostigma. Lat.: $43^{\circ}$ 36' 16.32" N; Long.: $116^{\circ} 43^{\prime} 14.52^{\prime \prime} \mathrm{E}$; Alt.: ca 1,260 m a.s.l. Coll.: Hur, J.-S. and Wang, X. Y. (CH-090347), 10.08.2009 (KoLRI 010961 sub Sedelnikovaea); the same locality, growing together with Acarospora, Protoparmeliopsis, Rhizoplaca, and Buellia, (CH-090348), (KoLRI 010962 sub Zeroviella). Xinjiang province, Urumqi city, Mt Tian, on rock. Lat.: $43^{\circ} 53^{\prime} 32.2^{\prime \prime} \mathrm{N}$; Long.: 88 06' 08.8" E; Alt.: ca 2,153 m a.s.l. Coll.: Oh, S.-O. and Hur, J.-S. (CH-130078), 14.07.2013 (KoLRI 019154); the same locality, (CH-130074), (KoLRI 019150); the same locality, (CH-130071), (KoLRI 019147); the same locality, Lat.: $43^{\circ}$ 
53' 34.5" N; Long.: 88 06' 23.9" E; Alt.: ca 2,094 m a.s.l. (CH-130065), (KoLRI 019141); the same locality, growing together with Anaptychia sp. and Aspicilia, (CH-130057), (KoLRI 019133 sub Zeroviella); the same locality, growing together with Lobothallia sp. and Aspicilia, Lat.: $43^{\circ} 53^{\prime} 38.7^{\prime \prime}$ N; Long.: $88^{\circ} 06^{\prime}$ 31.5" E; Alt.: ca 2,066 m a.s.l. (CH-130016), (KoLRI 019092 sub Zeroviella); the same locality, growing together with Protoparmeliopsis muralis and Aspicilia, Lat.: $43^{\circ} 53^{\prime} 34.1^{\prime \prime} \mathrm{N}$; Long.: 88 07'46.6" E, Alt.: ca 2,017 m a.s.l. (CH-130007), (KoLRI 019083 sub Zeroviella); the same locality, growing together with Protoparmeliopsis muralis, (CH-130006), (KoLRI 019082 sub Zeroviella); the same locality, growing together with Acarospora and Aspicilia, Lat.: 43 $53^{\prime}$ 20.9" N; Long.: 88 $08^{\circ}$ 05.7" E; Alt.: ca 1,962 m a.s.l. (CH-130087-1), (KoLRI 019164 sub Zeroviella); the same locality, growing together with Caloplaca biatorina, Acarospora, (CH-130101), (KoLRI 019178 sub Zeroviella). - Xinjiang province, Urumqi city, Mt Tian, the first Bingchuan, on rock, growing together with

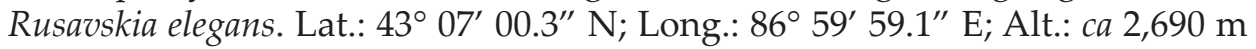
a.s.l. Coll.: Oh, S.-O. and Hur, J.-S. (CH-130256), 18.07.2013 (KoLRI 019336 sub Rusavskia elegans). - Xinjiang province, Urumqi city, Wucaicheng, on rock. Lat.: $45^{\circ} 04^{\prime}$ 56.9" N; Long.: 89 09' 54.0" E; Alt.: ca $882 \mathrm{~m}$ a.s.l. Coll.: Oh, S.-O. and Hur, J.-S. (CH-130140), 16.07.2013 (KoLRI 019217). - India. Uttaranchal, Chamoli district, Badrinath, Mana village, on rock. Coll.: Shukla, V. and Joshi, Y., 21.06.2005 (LWG 05-005253). - Uttarakhand, Chaniali district, Jumma, on rock, growing together with Rusavskia elegans and Caloplaca biatorina. Coll.: Rawat, S., 3.07.2007 (LWG 07-008609); Chamali district, Malari, on rock. Coll.: Rawat, S., 24.06.2007 (LWG 07-008609, LWG 07-008620); Badrinath, Mana, on rock. Coll.: Shukla, V. and Joshi, Y., 21.06.2005 (LWG 05-005383); Chamoli district, $1 / 2 \mathrm{~km}$ before Malari, on way to Niti, on rocks. Alt.: ca 3,086 $\mathrm{m}$ a.s.l. Coll.: Upreti, D. K. and Nayaka, S., 19.08.2007 (LWG 07-011225). - This species was recently described from Eurasia and North Africa (Kondratyuk 2015c). New to China and India!

Acknowledgements - KS and LL are grateful to Dr Jae-Seoun Hur (Sunchon, South Korea) for his kind help during stay in the KoLRI in 2015 and 2016 and during the field work, and Konstanze Bensch (MycoBank, UK) for corrections of Latin names. This work was supported by the Korea National Research Resource Centre Program, the Korean Forest Service Program (KNA 2012) through the Korea National Arboretum, (for LL) the Hungarian Scientific Research Fund (OTKA K81232), and (for SK) in part by The Ministry of Education and Science of Ukraine (M/90-2015 and M/34-2016) and by Korean Brain Pool Program (161S-4-3-1659). 


\section{REFERENCES}

Andreev, M. (2010): Halecania santessonii, a new lichenicolous lichen from Russia. - Lichenologist 42(3): 249-252. http://dx.doi.org/10.1017/s0024282909990703

Aptroot, A. and Cáceres, M. E. S. (2016): Two new lecanoroid Caloplaca (Teloschistaceae) species from gneiss inselbergs in equatorial Brazil, with a key to tropical lecanoroid species of Caloplaca s. lat. - Lichenologist 48(3): 201-207. http://dx.doi.org/10.1017/ s0024282916000049

Aptroot, A. and Moon, K. H. (2014): 114 new reports of microlichens from Korea, including the description of five new species, show that the microlichen flora is predominantly Eurasian. - Herzogia 27: 347-365. http://dx.doi.org/10.13158/heia.27.2.2014.347

Arup, U., Ekman, S., Lindblom, L. and Mattsson, J.-E. (1993): High performance thin layer chromatography (HPTLC), an improved technique for screening lichen substances. Lichenologist 25(1): 61-71. http://dx.doi.org/10.1017/s0024282993000076

Brako, L. (1991): Phyllopsora (Bacidiaceae). - Flora Neotropica 55: 1-66.

Breuss, O. (2002): Flechten aus Nicaragua. - Linzer Biol. Beitr. 34(2): 1053-1069.

Candan, M. and Halıc1, M. (2009): Two new lichenicolous Arthonia species from Turkey. Mycotaxon 107: 209-213. http://dx.doi.org/10.5248/107.209

Coppins, B. J. (1988): Skyttea refractiva, a new lichenicolous discomycete. - Notes Roy. Bot. Gard. Edinburgh 45: 171-173.

Diederich, P. (1986): Lichenicolous fungi from the Grand Duchy of Luxembourg and surrounding areas. - Lejeunia 119: 1-26.

Diederich, P. and Etayo, J. (2000): A synopsis of the genera Skyttea, Llimoniella and Rhymbocarpus (lichenicolous Ascomycota, Leotiales). - Lichenologist 32(5): 423-485. http:// dx.doi.org/10.1006/lich.2000.0290

Döbbeler, P. and Vězda, A. (1982): Macentina hepaticola, eine neue Flechte aus Zaire. Mitt. Bot. Staatss. München 18: 1-8.

Ertz, D., Diederich, P. and Miadłikowska, J. (2004): The lichenicolous Opegrapha species (Roccellaceae, Ascomycota) with 3-septate ascospores on Pertusaria and Ochrolechia. - Bot. J. Linn. Soc. 144: 235-241. http://dx.doi.org/10.1111/j.1095-8339.2003.00239.x

Etayo, J. and Diederich, P. (1996): Lichenicolous fungi from the Western Pyrenees, France and Spain. III. Species on Lobaria pulmonaria. - Bull. Soc. Nat. Luxembourg. 97: 93-118.

Ferraro, L. I. and Michlig, A. (2013): New species and additional records of Coenogonium (Ostropales: Coenogoniaceae) from southern South America. - Lichenologist 45(4): 497-504. http://dx.doi.org/10.1017/s0024282913000169

Galloway D. J. (2007): Flora of New Zealand lichens. Rev. 2nd ed. Vol. 1. - Manaaki Whenua Press, Lincoln, New Zealand.

Giavarini, V., James, P. W. and Purvis, O. W. (2009): Rinodina. - In: Smith, C. M. et al. (eds): The lichens of Great Britain and Ireland. British Lichen Society, London, pp. 812-825.

Golubkova, N. S. (1978): Acarosporaceae. - In: Golubkova, N. S., Savicz, V. P. and Trass, H. H. (eds): Handbook of the lichens of the U.S.S.R. 5 Cladoniaceae-Acarosporaceae. Nauka, Leningrad, pp. 137-292.

Harada, H. (2003): Psoroglaena japonica (lichenized Ascomycota, Verrucariaceae), a new species from Chiba-ken, central Japan, with notes on Psoroglaena. - Lichenology 2(1): 5-10.

Harada, H. and Vězda, A. (1997): Dimerella kawanae (lichenized Ascomycota, Gyalectaceae) sp. nov. from Chiba-ken, central Japan. - Bryologist 100(4): 454-457. http://dx.doi. org/10.1639/0007-2745(1997)100[454:dklags]2.0.co;2

Hue, A. (1910): Lichenes morphologice et anatomice disposuit (continuatio). - Nouv. Arch. Mus. hist. nat. Paris, 5 sér. 2: 1-120. 
Joshi, Y., Upreti, D. K. and Sati, S. C. (2008): Three new species of Caloplaca from India. Lichenologist 40(6): 535-541. http://dx.doi.org/10.1017/s0024282908007652

Joshi, Y., Gagarina, L., Halda, J. P., Oh, S.-O. and Hur, J.-S. (2015): A new species and a new record of the lichen genus Coenogonium (Ostropales: Coenogoniaceae) from South Korea, with a world-wide key to crustose Coenogonium having prothalli. - Mycosphere 6(6): 667-672. http://dx.doi.org/10.5943/mycosphere/6/6/3

Kashiwadani, H., Moon, K.-H., Inoue, M., Thor, G. and Kim, Y.-S. (2002): Lichens of the Cheju Island, Republic of Korea I. The macrolichens. - National Science Museum Monographs 22, Tokyo, pp. 115-135.

Kondratyuk, S. Y. (2015): Agonimia blumii sp. n. (Verrucariales, lichen-forming Ascomycota), a new taxon from Eastern Asia. - Ukr. Bot. J. 72(3): 246-251. http://dx.doi. org/10.15407/ukrbotj72.03.246

Kondratyuk, S. Y. and Galloway, D. J. (1995): Some new species of lichenicolous fungi. Bibl. Lichenol. 58: 235-244.

Kondratyuk, S. Y., Lőkös, L. and Hur, J.-S. (2014b): New lichen-forming and lichenicolous fungi from Ukraine. - Acta Bot. Hung. 56(3-4): 361-368. http://dx.doi.org/10.1556/ ABot.56.2014.3-4.11

Kondratyuk, S. Y., Elix, J. A., Kärnefelt, I. and Thell, A. (2011): Four new Caloplaca species with depsidones. - Bibl. Lichenol. 106: 179-186.

Kondratyuk, S., Kärnefelt, I., Elix, J. A. and Thell, A. (2007): New species of the genus Caloplaca in Australia. - Bibl. Lichenol. 95: 341-386.

Kondratyuk, S. Y., Lőkös, L., Farkas, E., Oh, S.-O. and Hur, J.-S. (2015a): New and noteworthy lichen-forming and lichenicolous fungi 2. - Acta Bot. Hung. 57(1-2): 77-141. http:// dx.doi.org/10.1556/ABot.57.2015.1-2.10

Kondratyuk, S. Y., Lőkös, L., Farkas, E., Oh, S.-O. and Hur, J.-S. (2015b): New and noteworthy lichen-forming and lichenicolous fungi 3. - Acta Bot. Hung. 57(3-4): 345-382. http://dx.doi.org/10.1556/034.57.2015.3-4.7

Kondratyuk, S., Yatsyna, A. P., Lőkös, L., Galanina, I., Haji Moniri, M. and Hur, J.-S. (2013b): Three new Xanthoria and Rusavskia species (Teloschistaceae, Ascomycota) from Europe. - Acta Bot. Hung. 55(3-4): 351-365. http://dx.doi.org/10.1556/abot.55.2013.3-4.10

Kondratyuk, S. Y., Lőkös, L., Tschabanenko, S., Skirina, I., Galanina, I., Oh, S.-O. and Hur, J.-S. (2014c): Caloplaca kedrovopadensis sp. nova and some new lichens from the Primorsky region, Russia. - Acta Bot. Hung. 56(1-2): 125-140. http://dx.doi.org/10.1556/ ABot.56.2014.1-2.11

Kondratyuk, S. Y., Kärnefelt, I., Thell, A., Elix, J. A., Kim, J., Kondratiuk, A. S. and Hur, J.-S. (2015c): Brownlielloideae, a new subfamily in the Teloschistaceae (Lecanoromycetes, Ascomycota). - Acta Bot. Hung. 57(3-4): 321-341. http://dx.doi.org/10.1556/ ABot.57.2015.3-4.6

Kondratyuk, S., Lőkös, L., Tschabanenko, S., Haji Moniri, M., Farkas, E., Wang, X. Y., Oh, S.-O. and Hur, J.-S. (2013a): New and noteworthy lichen-forming and lichenicolous fungi. - Acta Bot. Hung. 55(3-4): 275-349. http://dx.doi.org/10.1556/ABot.55.2013.3-4.9

Kondratyuk, S. Y., Jeong, M. H., Yu, N. N., Kärnefelt, I., Thell, A., Elix, J. A., Kim, J., Kondratiuk, A. S. and Hur, J.-S. (2014a): A revised taxonomy for the subfamily Caloplacoideae (Teloschistaceae, Ascomycota) based on molecular phylogeny. - Acta Bot. Hung. 56(1-2): 93-123. http://dx.doi.org/10.1556/ABot.56.2014.1-2.10

Kondratyuk, S. Y., Lőkös, L. , Kim, J. A., Kondratiuk, A. S., Jeong, M.-H., Jang, S. H., Oh, S.O., Wang, X. Y. and Hur, J.-S. (2016b): Fauriea, a new genus of the lecanoroid caloplacoid lichens (Teloschistaceae, lichen-forming ascomycetes). - Acta Bot. Hung. 58(3-4): 303-318. http://dx.doi.org/10.1556/ABot.58.2016.3-4.6 
Kondratyuk, S. Y., Kim, J. A., Yu, N.-H., Jeong, M.-H., Jang, S. H., Kondratiuk, A. S., Zarei-Darki, B. and Hur, J.-S. (2015c): Zeroviella, a new genus of xanthorioid lichens (Teloschistaceae, Ascomycota) proved by three gene phylogeny. - Ukr. Bot. J. 72(6): 574-584. http://dx.doi.org/10.15407/ukrbotj72.06.574

Kondratyuk, S. Y., Lőkös, L., Halda, J. P., Haji Moniri, M., Farkas, E., Park, J. S., Lee, B. G., Oh, S.-O. and Hur, J.-S. (2016a): New and noteworthy lichen forming and lichenicolous fungi 4. - Acta Bot. Hung. 58(1-2): 75-136. http://dx.doi.org/10.1556/034.58.2016.1-2.4

Lendemer, J. C. (2015): Lecanora layana (Lecanoraceae), a new sorediate species widespread in temperate eastern North America. - Bryologist 118(2): 145-153. http:// dx.doi.org/10.1639/0007-2745-118.2.145

Lücking, R. (1999): Additions and corrections to the foliicolous lichen flora of Costa Rica. The family Gyalectaceae. - Lichenologist 31(4): 359-374. http://dx.doi.org/10.1017/ s002428299900047x

Lücking, R. (2008): Foliicolous lichenized fungi. - Flora Neotropica Monograph 103. The New York Botanical Garden Press, Bronx, New York, 866 pp.

Navarro-Rosinés, P. and Roux, C. (1998): Polycoccum clauzadei sp. nov. (Ascomycetes, Dothideales), champignon lichénicole non lichénisé sur Xanthoria elegans. - Mycotaxon 69: 327-337.

Orange, A. (1989): Macentina stigonemoides (Verrucariaceae), a new lichenized species from Great Britain and Ireland. - Lichenologist 21(3): 229-236. http://dx.doi. org/10.1017/s0024282989000459

Orange, A. (1991): Macentina dictyospora (Verrucariaceae), a new lichenized species from Sweden. - Lichenologist 23(1): 15-20. http://dx.doi.org/10.1017/S0024282991000063

Orange, A., Coppins, B. J. and Scheidegger, C. (1992): Buellia. - In: Purvis, O. W. et al. (eds): The lichen flora of Great Britain and Ireland. Natural History Museum Publications, London, pp. 129-137.

Orange, A., James, P. W. and White, F. J. (2001): Microchemical methods for the identification of lichens. - British Lichen Society, London, 101 pp.

Rivas Plata, E., Lücking, R., Aptroot, A., Sipman, H. J. M., Chaves, J. L., Umaña, L. and Lizano, D. (2006): A first assessment of the Ticolichen biodiversity inventory in Costa Rica: the genus Coenogonium (Ostropales: Coenogoniaceae), with a world-wide key and checklist and a phenotype-based cladistic analysis. - Fungal Diversity 23: 255-321.

Rose, F., James, P. W. and Orange, A. (2009): Thelopsis Nyl. (1855). - In: Smith, C. W., Aptroot, A., Coppins, B. J., Fletcher, A., Gilbert, O. L., James, P. W. and Wolseley, P. A. (eds): The lichens of Great Britain and Ireland. The British Lichen Society, London, pp. 889-891.

Roux, C. and Triebel, D. (1994): Révision des espèces de Stigmidium et de Sphaerellothecium (champignons lichénicoles non lichénisés, Ascomycetes) correspondant à Pharcidia epicymatia sensu Keissler ou à Stigmidium schaereri auct. - Bull. Soc. Linn. Provence 45: 451-542.

Roux, C., Triebel, D., Bricaud, O. and Le Coeur, D. (1995): Le Stigmidium lecidellae sp. nov. et remarques sur le genre Stigmidium (champignons lichénicoles non lichénisés, Ascomycètes). - Can. J. Bot. 73(4): 662-672. http://dx.doi.org/10.1139/b95-070

Sheard, J. W. (2004): Rinodina. - In: Nash, T. H. III, Ryan, B. D., Diederich, P., Gries, C. and Bungartz, F. (eds): Lichen flora of the Greater Sonoran Desert Region. Vol. 2. Lichens Unlimited, Arizona State University, Tempe, pp. 467-502.

Stizenberger, E. (1862): Beitrag zur Flechtensystematik. - Ber. Tätigk. St. Gallischen Naturwiss. Gesellsch. 1861-1862: 124-182. 
Thor, G. and Vězda, A. (1984): Einige neue oder bemerkenswerte Flechten mit gyalectoiden Apothecien von Nord-Indien und Nepal. - Folia Geobot. Phytotax. 19: 71-82.

Tønsberg, T. (1992): The sorediate and isidiate, corticolous, crustose lichens in Norway. Sommerfeltia 14: 1-331.

Triebel, D. and Cáceres, M. E. S. (2004): Stigmidium. - In: Nash, T. H. III, Ryan, B. D., Diederich, P., Gries, C. and Bungartz, F. (eds): Lichen flora of the Greater Sonoran Desert Region. Vol. 2. Lichens Unlimited, Arizona State University, Tempe, Arizona, pp. 703-707.

Upreti, D. K., Divakar, P. K. and Nayaka, S. (2003): Notes on species of the lichen genus Phyllopsora in India. - Bibl. Lichenol. 86: 185-191.

Vězda, A. (1968): Taxonomische Revision der Gattung Thelopsis Nyl. (Lichenisierte Fungi). - Folia Geobot. Phytotax. 3: 363-406. http://dx.doi.org/10.1007/bf02851816

Vězda, A. (1973): Foliicole Flechten aus der Republik Guinea. I. - Acta Mus. Silesiae, Ser. A. 22: 67-90.

Zhurbenko, M. P. and Kobzeva, A. A. (2014): Lichenicolous fungi from Northwest Caucasus, Russia. - Herzogia 27(2): 377-396. http://dx.doi.org/10.13158/heia.27.2.2014.377 